\title{
Effects of physical exercise on coronary risk factors : coagulation, fibrinolysis and lipid levels
}

Citation for published version (APA):

Ponjee, G. A. E. (1995). Effects of physical exercise on coronary risk factors : coagulation, fibrinolysis and lipid levels. [Doctoral Thesis, Maastricht University]. Rijksuniversiteit Limburg. https://doi.org/10.26481/dis.19950317gp

Document status and date:

Published: 01/01/1995

DOI:

10.26481/dis.19950317gp

Document Version:

Publisher's PDF, also known as Version of record

\section{Please check the document version of this publication:}

- A submitted manuscript is the version of the article upon submission and before peer-review. There can be important differences between the submitted version and the official published version of record.

People interested in the research are advised to contact the author for the final version of the publication, or visit the DOI to the publisher's website.

- The final author version and the galley proof are versions of the publication after peer review.

- The final published version features the final layout of the paper including the volume, issue and page numbers.

Link to publication

\footnotetext{
General rights rights.

- You may freely distribute the URL identifying the publication in the public portal. please follow below link for the End User Agreement:

www.umlib.nl/taverne-license

Take down policy

If you believe that this document breaches copyright please contact us at:

repository@maastrichtuniversity.nl

providing details and we will investigate your claim.
}

Copyright and moral rights for the publications made accessible in the public portal are retained by the authors and/or other copyright owners and it is a condition of accessing publications that users recognise and abide by the legal requirements associated with these

- Users may download and print one copy of any publication from the public portal for the purpose of private study or research.

- You may not further distribute the material or use it for any profit-making activity or commercial gain

If the publication is distributed under the terms of Article $25 \mathrm{fa}$ of the Dutch Copyright Act, indicated by the "Taverne" license above, 


\section{EFFECTS OF PHYSICAL EXERCISE ON CORONARY RISK FACTORS}

COAGULATION, FIBRINOLYSIS AND LIPID LEVELS

G.A.E. PONJEE 
Publicatie in de vorm van dit proefschrift werd mede mogelijk gemaakt door subsidie van de Dr. Ir. J.H.J. van der Laar stichting.

Universiteitsdrukkerij Technische Universiteit Delft, 1995.

ISBN : $90-9008063-5$ 


\title{
EFFECTS OF PHYSICAL EXERCISE ON CORONARY RISK FACTORS
}

\author{
COAGULATION, FIBRINOLYSIS AND LIPID LEVELS
}

\section{PROEFSCHRIFT}

ter verkrijging van de graad van doctor

aan de Rijksuniversiteit Limburg te Mastricht, op gezag van de rector magnificus, Prof. Mr. M.J. Cohen, volgens het besluit van het College van Dekanen,

in het openbaar te verdedigen op vrijdag 17 maart 1995 om 14.00 uur

door

GABRIELLE ANTOINETTE ELISE PONJEE GEBOREN OP 21 SEPTEMBER 1960 TE ROOSENDAAL 


\section{Promotor}

Prof. Dr. P.J. Brombacher

\section{Co-promotor}

Dr. J.W.J. van Wersch

\section{Beoordelingscommissie}

Prof. Dr. H. Kuipers, voorzitter

Prof. Dr. Dr. H. Greiling (RWTH, Aken)

Prof. Dr. P.G. Knipschild

Prof. Dr. J.A. Knottnerus

Prof. Dr. A. Sturk (Rijksuniversiteit Leiden) 
Voor Isabelle en ... 



\section{CONTENTS}

Chapter 1

Introduction

Chapter 2

Subjects, materials and methods

Chapter 3

Effects of long-term exercise of moderate intensity on anthropometric values and serum lipids and lipoproteins Eur $J$ Clin Chem Clin Biochem; accepted

\section{Chapter 4}

Long-term physical exercise and lipoprotein(a) levels in a previously sedentary male and female population Ann Clin Biochem 1995; 32: 1-5

Chapter 5

Prolonged endurance exercise and blood coagulation:

a 9 month prospective study

B1 Coag Fibrinol 1993; 4: 21-5

\section{Chapter 6}

Effect of long-term endurance exercise on fibrinolytic markers

Fibrinol 1993; 7: 397-400

\section{Chapter 7}

Prolonged physical conditioning and blood platelet release markers: a longitudinal study

Haemostas 1993; 23: 269-74 
Chapter 8

Regular physical activity and changes in risk factors for coronary heart disease; a nine-months prospective study submitted for publication

Chapter 9

General discussion

Summary

Samenvatting 147

Dankwoord 153

Curriculum vitae 155 


\section{CHAPTER 1}

INTRODUCTION 


\section{INTRODOCTION}

Since 1900, there has been a shift in cause of death from infectious disease to chronic diseases. Nowadays, coronary heart disease (CHD) is the leading killer in all developed countries worldwide. Since the costs for health care skyrocketed in most western countries in the last decades, emphasis on health care has turned more towards health promotion (1). Many countries have adopted prevention policies in order to reduce modifiable risk factors and hence the prevalence of $\mathrm{CHD}$. In 1991, the public health service in the United states published a document on National health promotion and disease prevention in order to improve the health of the nation by the year 2000 (2). This document contains several objectives to reduce risk for $\mathrm{CHD}$ and other diseases by means of changes in lifestyle. The risk reduction programme concerns control of risk factors such as smoking, elevated blood pressure and high serum cholesterol. Besides the attention paid to these risk factors, the major objective of the promotion activities is to improve the proportion of people, who engage regularly in moderate physical activity, 3 or more days a week. Overall, people in all age groups should exercise more at school, the workplace and during leisure time $(1-3)$.

\section{Physical exercise and coronary heart disease}

The first large epidemiologic study relating physical fitness with a reduced risk for $\mathrm{CHD}$ was published in 1953, concerning the occupational physical activities of London busdrivers (4). It was concluded that physically more active workers (conductors) had lower early mortality-rates than their sedentary colleagues (drivers). Most early researchers focused on activities at work, ignoring leisure time physical activity (5-9). A potential bias in these early studies is self-selection. Individuals who are less 
healthy may choose less physically demanding occupations. Another major problem is the fact that physical activity is very difficult to quantify. In addition, physical activity and physical fitness may be interrelated but are not synonymous (10). Later epidemiologic studies focused on overall physical activity, because of the decline in jobs demanding physical work and the concomitant increase in leisure time physical exercise (11-16). A meta-analysis conducted on 43, mostly well-designed epidemiologic studies, showed consistently an inverse relation between physical activity and the incidence of $\mathrm{CHD}$ (17). The relative risk of inactive life-style appeared to be comparable in magnitude to that of the established risk factors hypertension, hypercholesterolemia and smoking. More recently conducted prospective studies, all attempted to minimize the influence of possible coronary risk factors and self-selection of the subjects and have used improved methods to assess physical activity (18-21). The outcome of these investigations support the idea that a higher level of physical fitness is associated with a reduced risk for cardiovascular disease and early mortality. However, all epidemiologic studies, conducted so far, are observational in design, without randomization of the subjects. Confounding factors in these studies may be self-selection bias and clustering of atherosclerotic risk factors in the sedentary population, objective measurement of the amount of physical activity and the influence of other health promoting life-style adaptations in exercising individuals (23). Prospective studies on physical activity and the secondary prevention of myocardial infarction, revealed a significant reduction in coronary events in exercising patients (22). However, in most studies other life-style changes were incorporated like cessation of smoking and adaptation of the diet. 


\section{Atherosclerosis}

Atherosclerosis, the underlying cause in most cases of coronary heart disease, is not a single illness, but a multifactorial disorder (24-27). The primary lesion of atherosclerosis is the fatty streak, mainly consisting of lipid-loaded cells, the so called foam cells. Aortic fatty streaks are commonly seen in childhood, while coronary lesions occur in early adolescence. Advanced atherosclerosis is represented by the fibrous plaque, composed of a cap of intimal smooth muscle cells, connective tissue matrix, macrophages and $T$-lymphocytes and containing a core of lipids, cholesterol crystals, and cellular debris. Fibrous plaques already begin to develop in youth and young adulthood. By increasing in size, these plaques may rupture, exposing the highly thrombogenic internal constituents to the arterial blood. This may lead to thrombogenesis and vascular occlusion. Various theories have not yet fully elucidated the origin of early atherogenesis. The first step in atherogenesis may be endothelial injury of the intima, which may lead to attachment of monocytes/macrophages, T-lymphocytes and possibly platelets and migration of smooth muscle cells. All five principal cells involved in atherosclerosis endothelial cells, smooth muscle cells, macrophages, Tlymphocytes and platelets - are able to produce growth factors inducing proliferation of the lesion into a fibrous plaque.

\section{Risk factors}

Multiple epidemiologic, clinical and laboratory studies have identified several physiologic and life-style factors, which play a causative role in the incidence of coronary heart disease. Some of these risk factors are not modifiable biological factors. Among those, age is a important predictor for cardiovascular disease (28-30). Already by the age of 35 , coronary heart disease is the 
leading cause of death. A second important not modifiable risk factor is gender (28). Women have generally a lower risk for coronary heart disease than men, but the incidence is greatly increased after the menopause. The protective effect of female sex hormones, inducing more favourable lipid profiles and more specifically, a higher serum level of HDL-cholesterol, seems to be the underlying cause for this. Furthermore, genetic factors are highly prognostic for the incidence of coronary heart disease $(28,29)$. These include a family history of heart attacks before age 50, of hypertension and of lipid or other metabolic dysfunctions.

In addition, three major potentially modifiable, risk factors for atherosclerosis are established. A high blood pressure is strongly correlated to the incidence of coronary heart disease $(28,30-33)$. Although, a high blood pressure is often genetically determined, it can be lowered by a number of non-drug measures, like control of sodium intake, proper weight maintenance, and quit smoking. Exercise is also supposed to have favourable effects on moderately elevated blood pressure levels (31).

Cigarette smoking is an important life-style factor associated with the incidence of cardiovascular disease $(28,29)$. Direct effects of nicotine and carbon monoxide poisoning of cells in the vessel wall have been demonstrated (28). In addition, smoking induces an increase in plasma fibrinogen concentration and has a negative influence on serum lipoprotein levels (28). A tight coupling exists between smoking and other adverse lifestyle habits, like excessive coffee intake and the consumption of low fibre, high fat diets (29).

Hypercholesteremia is the third major modifiable risk factor $(28,30-34)$. Plasma serum cholesterol levels have been shown to correlate strongly with cardiovascular disease in both case control and prospective studies. This correlation is almost entirely due to the high association between the incidence of coronary heart disease and serum 
LDL-cholesterol levels $(32,33)$. A strong, inverse correlation exists between HDL-cholesterol and cardiovascular disease (34). The mechanism through which HDL-cholesterol exhibits its protective effect is not fully elucidated, but the mechanism of action may involve transport of cholesterol back to the liver, which in its turn, catabolizes and excretes excessive amounts of cholesterol (34).

other, potentially modifiable factors, which have been associated with the pathogenesis of cardiovascular disease, include obesity, glucose intolerance, serum triglycerides, dietary habits and a high alcohol consumption $(28,29,32,33)$. A sedentary life-style and poor physical fitness is another 'bad habit' in relation to cardiovascular disease $(18,19,33)$.

However, these known risk factors do not fully explain the variability in atherogenic lesions, leaving space for haemostatic factors to play a role in the development of cardiovascular disease, including thrombogenesis. Several large prospective epidemiologic studies have designated elevated levels of fibrinogen as an independent risk factor for cardiovascular diseases $(35,36)$. This association was of the same order of magnitude as other powerful predictors for cardiovascular disease, like systolic blood pressure, cholesterol level, weight, smoking etc. The mechanism by which fibrinogen may promote atherosclerosis and thrombosis is not fully understood. Fibrinogen affects haemostasis, platelet aggregation, endothelial function and is the major determinant of plasma viscosity. Through these properties, fibrinogen may reduce blood flow, enhance platelet aggregability and induce atherogenesis (35). The role of fibrinogen as acute fase reactant should also be considered in relation to cardiovascular disease. since several aspects of atherosclerosis resemble a mild inflammatory process, fibrinogen may also be a risk marker in stead of a risk factor $(35,36)$. One of the most important causes of 
increased fibrinogen levels is cigarette smoking (36). This correlation is dose dependent, and more strongly in men than in women. Age and sex differences are also important determinants of plasma fibrinogen concentration $(35,36)$.

A reduced fibrinolytic capacity, mainly due to increased levels of plasminogen activator inhibitor (PAI), may be related to the incidence of cardiovascular disease (37). PAI plays an important role in fibrinolysis by its inhibitory binding to tissue plasminogen activator. The conversion of plasminogen to plasmin by tissue plasminogen activator, is an important step in the fibrinolytic process. Elevated PAI levels may disturb the balance between haemostasis and fibrinolysis, facilitating the deposition of fibrin on the vessel wall. Increased PAI levels are observed in patients suffering from coronary heart disease and may also be related to other risk factors, like total cholesterol and triglycerides (37).

Circulating platelets may not be involved in the initial development of the fatty streak. But activated platelets can release a number of important growth factors, like platelet derived growth factor and platelet factor 4 , a heparin binding protein (38). In this way platelets will stimulate plaque development. Furthermore platelets play a major role in acute cardiovascular events, by adherence to the atherosclerotic plaque and hence initiating thrombus formation (38).

A strong and independent predictor of cardiovascular disease seems to be lipoprotein(a), which has been found in arterial walls on sites of plaque formation (39-41). Lipoprotein(a) is assembled from LDL-cholesterol and a glycoprotein, apolipoprotein(a) (apo(a)). Apo(a) shows a striking homology with plasminogen, a principal component of the fibrinolytic system $(39,41)$. But, in contrast to plasminogen, lipoprotein(a) has no proteolytic activity. The structural similarity between an atherogenic lipoprotein and a proteolytic enzyme of the fibrinolytic 
system, is potentially the first evidence for a molecular based link between atherosclerosis and thrombosis $(41,42)$. Although the actual function of lipoprotein(a) is still unclear, it has been speculated that lipoprotein(a) competes with plasminogen for fibrin binding sites and in this way can inhibit fibrinolysis (41-45). However, clinical studies so far, have failed to demonstrate reduced capacity of the fibrinolytic system in persons with high level of lipoprotein(a).

\section{Physical exercise and the risk factor profile}

Regular performance of dynamic exercise for at least 20 to 30 minutes, for three or more times a week, induces cardiovascular or aerobic fitness in the exercising individual (46). Physical training directly promotes cardiorespiratory fitness through several adaptations of the body due to the increased workload, like a reduction in resting heart rate, an increase in stroke volume and a rise in maximal oxygen consumption $(46,47)$. In addition, regular exercise seems to produce a variety of mental benefits, like a feeling of well-being, better management of stress and anxiety, and better dietary control (46). Also a number of physiologic effects are attributed to exercise. Physical exercise and physical fitness coincide with a reduced risk for cardiovascular disease $(16,17)$. The mechanism through which physical activity may reduce cardiovascular morbidity and mortality is still unclear. Regular physical training may beneficially influence several risk factors e.g. blood pressure, and serum lipids and lipoproteins (19-22). This concept was primarily derived from cross-sectional studies, comparing endurance trained athletes with matched sedentary controls (48-52). Major differences between active people and their inactive counterparts, appear to be the more favourable serum lipid status (52-54). More specifically, exercise is associated with reduced serum levels of triglycerides and, although not consistently, LDL- 
cholesterol and raised levels of HDL-cholesterol (34,5355). Cross-sectional studies are inevitably biased due to self-selection of the individuals under investigation. Physical active subjects may differ from sedentary individuals in body mass and body composition and the use of cigarettes, alcohol and other dietary or life-style habits $(50,51-55)$. Longitudinal epidemiologic studies on the effect of physical exercise on the risk factor profile differ greatly in design, duration and methodology, so results are difficult to compare (55). Most of these studies support the results derived from cross-sectional data, although often only marginal effects of habitual exercise on blood lipids are described (56-60). Lipoprotein(a), an atherogenic substance, is a topic in contemporary research (40-45). Serum lipoprotein(a) concentrations seern to be largely unrelated to other risk factors and are relatively unaffected by changes in diet or medications, currently used to treat hypercholesterolemia $(40,45)$. These observations support the concept that lipoprotein(a) metabolism is largely independent to that of other lipoproteins and a study to the effect of exercise on lipoprotein(a) is therefore of great interest. However, up to now, only few studies report on the effect of regular exercise on serum lipoprotein(a) levels $(61,62)$.

Exercise may influence haemostasis through a number of pathways (63). The observation that strenuous physical exercise can cause hyperfibrinolysis of the blood, was first described by Biggs (64). Since then, this observation has been confirmed by a number of investigators $(63,65-69)$. Fibrinolytic activity is transiently increased after vigourous exercise, mainly caused by an increased release of tissue plasminogen activator from the vessel wall $(65,67)$. In response, plasminogen activator inhibitor levels are generally reduced acutely after exercise (6672). The influence of physical conditioning on the resting fibrinolytic potential is less extensively studied and the 
results seems to depend greatly on the exercise protocol and laboratory tests used as well as the subjects under investigation $(67,68,72)$. Physical conditioning appears to increase the amount of active plasma tissue plasminogen activator by decreasing the plasma concentrations of plasminogen activator inhibitor $(71,72)$. Because of presumed correlation between $\mathrm{PAI}$ and the incidence of coronary heart disease, the potentially beneficially influence of exercise on plasma PAI concentrations is recently extensively studied $(68-72)$.

The effect of physical exercise on fibrinogen concentrations is a subject of controversy. While in some epidemiologic studies, physical conditioning was found to be inversely associated with plasma fibrinogen concentrations, in other studies no effect or the opposite was observed $(73,74)$. Physical exercise influences in vitro clotting times. The activated partial thromboplastin time can be significantly shortened post exercise, mainly caused by increased levels of factor vIII activity and von willebrand factor antigen, released from the endothelial cells (63). However, actual activation of the coagulation cascade appears to be unusual, because generated thrombin is inactivated by antithrombin III (63). Some studies on increased levels of thrombin-antithrombin III complexes, but this is mainly observed in the acute post exercise state $(63,65,66,70)$.

Platelet counts increase significantly with strenuous exercise, due to the release of thrombocytes from the spleen and other sites of temporary trapping, like the pulmonary circulation $(75,76)$. However, platelet numbers in plasma of trained athletes are generally not elevated in comparison to inactive controls (63). Whether exercise induces platelet activation is controversial. Several studies on the effect of physical exercise on blood platelets, were conducted with in vitro aggregation techniques (70,75-77). In some studies, but not all, an increased 
platelet activation is observed acutely after exercise, but not after prolonged physical conditioning (76-79). Apart from the great variability in study design, the bad reproducibility of the in vitro tests, is an additional source of error. Other investigators have measured the plasma concentrations of platelet specific proteins as a response to physical exercise $(80,81)$. The equivocal results obtained by the various studies, may reflect the difficulty to standardize exercise intensity, blood collection techniques and test procedures $(63,80,81)$.

\section{Outline of this thesis}

Extensive literature exists on the effect of physical exercise on anthropometric and blood variables. However, cross-sectional studies are biased due to confounding factors, like self selection of the individuals and the influence of other life-style habits (82-84). The majority of investigations concerns groups of either men or women $(53-56,85)$. In studies including intensive guidance of the training sessions, often a relatively short follow-up from several weeks to few months is established $(56,57,60,65,85,86)$. In most studies, blood parameters are measured within 24-48 hours after an exercise test or running contest, reflecting acute post exercise effects $(54,56,57,68,72)$. Finally, only few studies report on the relation between the changes in blood parameters under the influence of long-term regular exercise (58).

The present study was started in order to investigate the non-acute effects of a nine months training programme on lipids, parameters of the haemostatic system and the relation between these variables, in blood of previously sedentary men and women. The selection procedure of the subjects and the exercise programme as well as materials and methods are presented in chapter 2. The effect of physical conditioning on serum lipids, lipoproteins and on some anthropometric parameters, is reported in the next 
chapter. The effect of exercise on serum lipoprotein(a) concentrations was studied in chapter 4. Chapter 5 contains results on physical training and blood coagulation and in the next chapter the influence of regular exercise on fibrinolysis is described. Chapter 7 focuses on the nonacute effects of exercise on blood platelets. Finally, in chapter 8 , the influence of physical conditioning on various factors of the risk factor profile and the correlation between these parameters is discussed. 


\section{REFERENCES}

1. Bijnen FCH, Caspersen CJ, Mosterd WL. Physical inactivity as a risk factor for coronary heart disease: a wHO and International society and Federation of Cardiology position statement. Bulletin of the World Health Organization $1994 ; 72(1): 1-4$.

2. Public Health Service, U.S. Department of Health and Human Services (1991). Healthy People 2000: National Health Promotion and Disease Prevention Objectives. DHHS Publication No. (PHS) 91-50212. Superintendent of Documents, Government Printing office, washington, DC 20402-9325.

3. Reed FE, Ward DS. Youth health - the key to lifelong fitness and the challenge to health care in the next century. The Journal of the South Carolina Medical Association $1993 ; 89(8): 377-80$.

4. Morris JN, Heady JA, Raffle PAB, Roberts CG, Parks JW. Coronary heart-disease and physical activity of work. Lancet $1953 ; i$ : $1053-1120$.

5. Brand RJ, Paffenbarger RS, Sholtz RI, Kampert JB. Work activity and fatal heart attack studied by multiple logistic risk analysis. Am J Epidemiol 1979; 110: 5262 .

6. Kahn HA. The relationship of reported coronary heart disease mortality to physical activity of work. Am J Public Health 1963; 53: 1058-67.

7. Menotti A, Puddu V. Ten-year mortality from coronary heart disease among 172.000 men classified by occupational physical activity. Scand $J$ Work Environ Health 1979; 5: 100-8.

8. Paffenbarger RS, Hale WE, Brand RJ, Hyde RT. Workenergy level, personal characteristics, and fatal heart attack: A birth-cohort effect. Am $J$ Epidemiol 1977; 105: 200-13.

9. Taylor HL, Kelpetar E, Keys A, Parlin W, Blackburn H, et al. Death rates among physically active and sedentary employees of the railroad industry. Am $J$ Public Health 1962; 52: 1697-1707.

10. Blair SN, Kohl HW, Paffenbarger RS, Clark DG, Cooper KH, Gibbons LW. Physical fitness and allcause mortality. A prospective study of healthy men and women. JAMA 1989; 262: 2395-2401.

11. Garcia-Palmieri MR, Costas R, Curz-Vidal M, Sorlie PD, Havlik RJ. Increased physical activity. A protective factor against heart attacks in Puerto Rico. Am J Cardiol 1982; 50: 749-55.

12. Kannel WB, Sorlie P. Some health benefits of physical activity. The Framingham study. Arch Intern Med 1979; 139: 857-61.

13. Siscovick DS, Weiss NS, Hallstrom AP, Inui TS, Peterson DR. Physical activity and primary cardiac arrest. J Am Med AssoC 1982; 248: 3113-17. 
14. Wilhelmsen $\mathrm{L}$, Tibblin G, Aurell M. Bjure J, EkstromJodal B, Grimby G. Physical activity, physical fitness and risk of myocardial infarction. Adv Cardiol 1976; 18: $217-30$.

15. Yano $\mathrm{K}$, Reed DM, MCGee DL. Ten-year incidence of coronary heart disease in the Honolulu Heart Program. Am J Epidemiol 1984; 119: 653-66.

16. Paffenbarger RS, Hyde RT, Wing AL, Hsieh C. Physical activity, all-cause mortality, and longevity of college alumni. N Engl J Med 1986; 314: 605-13.

17. Powell KE, Thompson PD, Caspersen CJ, Kendrik JS. Physical activity and the incidence of coronary heart disease. Ann Rev Public Health 1987; 8: 253-87.

18. Sandvik L, Erikssen J, Thaulow E, Erikssen G, Mundal $R$, Rodahl $\mathrm{K}$. Physical fitness as a predictor of mortality among healthy, middle-aged Norwegian men. N Engl J Med 1993; 8: 533-7.

19. Paffenbarger RS, Hyde RT, Wing AL, Lee I-M, Jung DL, Kampert JB. The association of changes in physicalactivity level and other lifestyle characteristics with mortality among men. N Engl J Med 1993; 328: 53845 .

20. Lakka $T A$, Venãläinen JM, Rauramaa $R$, Salonen $R$, Tuomilehto J, Salonen JT. Relation of leisure-time physical activity and cardiorespiratory fitness to the risk of acute myocardial infarction in men. $\mathrm{N}$ Engl J Med 1994; 330: 1549-54.

21. Ekelund L-G, Haskell WL, Johnson JL, Whaley FS, Criqui MH, Sheps DS. Physical fitness as a predictor of cardiovascular mortality in asymptomatic North American men. N Engl J Med 1988; 319: 1379-84.

22. Fletcher GF, Long-term exercise in coronary artery disease and other chronic disease states. Heart Lung $1984 ; 13: 28-46$.

23. Curfman GD. The health benefits of exercise. A critical reappraisal. N Engl J Med 1993; 328: 574-5.

24. Wissler RW. Theories and new horizons in the pathogenesis of atherosclerosis and the mechanisms of clinical effects. Arch Pathol Lab Med 1992; 116: 128191 .

25. Badimon JJ, Fuster V, Chesebro JH, Badimon L. Coronary Atherosclerosis. A Multifactorial Disease. Circulation 1993; 87 (supplII) : II-3-II-16.

26. Strong JP. Atherosclerotic Lesions. Natural History, Risk Factors, and Topography. Arch Pathol Lab Med 1992 ; 116 : $1268-75$.

27. Ross $R$. The pathogenesis of atherosclerosis - an update. N Engl J Med 1986; 314: 488-500.

28. Leon AS. Age and other predictors of coronary heart disease. Med Sci Sports Exerc 1987; 19: 159-67.

29. Hostmark AT, Berg J, Brudal S, Berge SR, Kierulf $P$, Bjerkedal $T$. Coronary risk factors in middle-aged men as related to smoking, coffee intake and physical 
activity. Scand J Soc Med 1992; 20: 196-203.

30. Wright $\mathrm{L}$, Murcer $\mathrm{S}$, Adams $\mathrm{K}$, welch $\mathrm{S}$. The factor analytic structure of seven physical CHD risk factors: a replication study. J Clin Psychol 1994; 50: 216-9.

31. Bovens AM, Baak Van MA, Vrencken JG, Wijnen JA, Saris WH, Verstappen FT. Physical activity, fitness, and selected risk factors for CHD in active men and women. Med Sci Sports Exerc 1993; 25: 572-6.

32. Bainton D, Miller $\mathrm{NE}$, Bolton $\mathrm{CH}$, Yarnell JWG, Sweetnam PM, Baker IA, Lewis B, Elwood PC. Plasma triglyceride and high density lipoprotein cholesterol as predictors in ischaemic heart disease in British men. The Caerphilly and Speedwell Collaborative Heart Disease Studies. Br Heart J 1992; 68: 60-6.

33. Håheim LL, Holme I, Hjermann I, Leren P. Risk Factors of stroke incidence and mortality. A 12-year follow-up of the Oslo study. Stroke 1993; 24: 1484-9.

34. Gordon T, Castelli WP, Hjortland MC, Kannel WB, Dawber TR. High density lipoprotein as a protective factor against coronary heart disease. The Framingham study. Am J Med 1977; 62: 707-14.

35. Ernst E, Resch KL. Fibrinogen as a Cardiovascular risk factor: A meta-analysis and review of the literature. An Int Med 1993; 118: 956-63.

36. Kannel WB, Wolf PA, Castelli WP, D'Agostino RB. Fibrinogen and risk of cardiovascular disease. The Framingham study. JAMA 1987; 258: 1183-6.

37. Hamsten A, Walldius G, Szamosi A, Blombäck M, Faire U, Dahlén G, Landou C, Wiman B. Plasminogen activator inhibitor in plasma: risk factor for recurrent myocardial infarction. Lancet 1987; 2(8549): 3-9.

38. Becker RC. Seminars in thrombosis, thrombolysis and vascular biology 3. Platelet activity in cardiovascular disease. Cardiology 1991; \&9: 49-63.

39. Oshima $S$, Uchida $K$, Yasu $T$, Uno $K$, Nonogi $H$, Haze $K$. Transient increase of plasma lipoprotein(a) in patients with unstable angina pectoris. Does lipoprotein(a) alter fibrinolysis? Arterioscler Tromb 1991; 11: 1772-7.

40. Rosengren A, Wilhelmsen $L$, Eriksson E, Risberg $B$, Wedel $H$. Lipoprotein(a) and coronary heart disease: a prospective case-control study in a general population sample of middle aged men. Br Med J 1990; 301: 124851 .

41. Smith EB, Crosbie L. Does lipoprotein(a) (Lp(a)) compete with plasminogen in human atherosclerotic lesions and trombi? Atherosclerosis 1991; 89: 127-36.

42. Hajjar KA, Gavish D, Breslow JL, Nachman RL. Lipoprotein(a) modulation of endothelial cell surface fibrinolysis and its potential role in atherosclerosis. Nature 1989; 339: 303-5.

43. Qiu S, Théroux P, Genest J, Solymoss BC, Robitaille D, Marcil M. Lipoprotein(a) blood levels in unstable 
angina pectoris, acute myocardial infarction, and after thrombolytic therapy. Am $J$ Cardiol 1991; 67: 1175-9.

44. Hervio L, Chapman MJ, Thillet J, Loyau S, Anglés-Cano E. Does apoliprotein(a) heterogeneity influence lipoprotein(a) effects on fibrinolysis? Blood 1993; 82: $392-7$.

45. Jenner JL, ordovas JM, Lamon-Fava S, Schaefer MM, Wilson PWF, Castelli WP, Schaefer EJ. Effects of age, sex, and menopausal status on plasma lipoprotein(a) levels. The Framingham offspring study. Circulation $1993 ; 87$ : 1135-41.

46. Alexander $\mathrm{S}$. Physiologic and biochemical effects of exercise. Clin Biochem 1984; 17: 126-31.

47. Braun LT, Exercise physiology and cardiovascular fitness. Nurs Clin North Am 1991; 26: 135-47.

48. Northcote RJ, Canning GC, Todd IC, Ballantyne D. Lipoprotein profiles of elite veteran endurance athletes. Am J Cardiol 1988; 61: 934-6.

49. Mena P, Maynar M, Campillo JE. Plasma lipid concentrations in professional cyclists after competitive cycle races. Eur J Appl Physiol 1991; 62: 349-52.

50. Wood PD, Stefanick ML, Dreon DM, Frey-Hewitt B, Garay SC, Williams PT, Superko HR, Fortmann SP, Albers JJ, Vranizan KM, Ellsworth NM, Terry RB, Haskell WL. Changes in plasma lipids and lipoproteins in overweight men during weight loss through dieting as compared with exercise. N Engl J Med 1988; 319: 11739.

51. Sady SP, Cullinane EM, Saritelli A, Bernier D, Thompson PD. Elevated high-density lipoprotein cholesterol in endurance athletes is related to enhanced plasma triglyceride clearance. Metabolism 1988; 37: 568-72.

52. Stray-Gundersen J, Denke MA, Grundy SM. Influence of lifetime cross-country skiing on plasma lipids and lipoproteins. Med Sci Sports Exerc 1991; 23: 695-702.

53. Hespel P, Lijnen P, Fagard R, Hoof Van R, Rosseneu M, Amery A. Changes in plasma lipids and apoproteins associated with physical training in middle-aged sedentary men. Am Heart J 1988; 115: 786-92.

54. Ekstedt $B$, Jönsson $E$, Johnson $O$. Influence of dietary fat, cholesterol and energy on serum lipids at vigorous physical exercise. Scand $\mathrm{J} C \mathrm{Cl}$ in Lab Invest 1991; 51: 437-42.

55. Schieken RM. Effect of Exercise on Lipids. Annals New York Academy of Sciences 1991; 623: 269-74.

56. Mendoza SG, Carrasco H, Zerpa A, Briceno $Y$, Rodriguez F, Speirs J, Glueck CJ. Effect of physical training on lipids, lipoproteins, apolipoproteins, lipases, and endogenous sex hormones in men with premature myocardial infarction. Metabolism 1991; 40: 368-77. 
57. Raz I, Rosenbilt $H$, Kark JD. Effect of moderate exercise on serum lipids in young men with low high density lipoprotein cholesterol. Arteriosclerosis $1988 ; 8: 245-51$.

58. Young DR, Haskell WL, Jatulis DE, Fortmann SP. Associations between changes in physical activity and risk factors for coronary heart disease in a community-based sample of men and women: The stanford five-city project. Epidemiol 1993; 138: 205-15.

59. Adamopoulos PN, Macrilakis K, Papamichael Ch, Malakos I, Panayidis $N$, Moulopoulos D. Physical activity and relationship with coronary heart disease risk factors. Acta Cardiol 1993; 153: 523-34.

60. Grant $S$, Aitchison $T$, Pettigrew AR, orrell JM. The effects of a university fitness programme on healthrelated variables in previously sedentary males. Br $\mathrm{J}$ Sp Med 1992; 26: 39-44.

61. Austin A, Warty $V$, Janosky J, Arslanian $S$. The relationship of physical fitness to lipid and lipoprotein(a) levels in adolescents with IDDM. Diabetes Care 1993; 16: 421-5.

62. Lobo RA, Notelovitz M, Bernstein L, Khan FY, Ross RK, Paul WL. Lp(a) lipoprotein: relationship to cardiovascular disease risk factors, exercise, and estrogen. Am J Obstet Gynecol 1992; 166: 1182-90.

63. Streiff $M$, Bell WR. Exercise and hemostasis in humans. Sem Hematol 1994; 31: 155-65.

64. Biggs R, Macfarlaine RG. Observations on fibrinolysis. Experimental activity produced by exercise or adrenaline. Lancet $1947 ; 402-5$.

65. Dufaux B, Order U, Liesen H. Effect of a short maximal physical exercise on coagulation, fibrinolysis, and complement system. Int J Sports Med 1991; 12: S38-S42.

66. Arai $M$, Yorifuji $H$, Ikematsu $S$, Nagasawa $H$, Fujimaki $M$, Fukutake $K$, Katsumura $T$ Ishii $T$, Iwane $H$. Influences of strenuous exercise (triathlon) on blood coagulation and fibrinolytic system. Thromb Res 1990; 57: 465-471.

67. El-sayed MS. Exercise intensity-related responses of fibrinolytic activity and vasopressin in man. Med Sci Sports Exerc 1990; 22: 494-500.

68. Molz AB, Heyduck B, Lill H, Spanuth E, Röcker L. The effect of different exercise intensities on the fibrinolytic system. Eur J Appl physiol 1993; 67: 298304 .

69. Stratton JR, Chandler WL, Schwartz RS, Cerqueira MD, Levy WC, Kahn SE, Larson VG, Cain KC, Beard JC, Abrass IB. Effects of physical conditioning on fibrinolytic variables and fibrinogen in young and old healthy adults. Circulation 1991; 83: 1692-7.

70. Watts EJ. Heamostatic changes in long-distance runners and their relevance to the prevention of ischaemic heart disease. Bl Coag Fibrinol 1991; 2: 221-5. 
71. Gris JC, Schvéd JF, Aguilar-Martinez P, Arnaud A, Sanchez $N$. Impact of Physical Training on Plasminogen Activator Inhibitor Activity in sedentary Men. Fibrinol 1990; 4: 97-8.

72. Geus De EJC, Kluft C, Bart De ACW, Doornen Van LJP. Effects of exercise training on plasminogen activator inhibitor activity. Med Sci sports Exerc 1992; 24: 1210-9.

73. Mфller L, Kristensen TS. Plasma fibrinogen and ischemic heart disease risk factors. Arterioscler and Thromb 1991; 11: 344-50.

74. Rosengren A, wilhelmsen $L$, Welin L, Tsipogianni A, Teger-Nilsson A-C, wedel $H$. Social influences and cardiovascular risk factors as determinants of plasma fibrinogen concentration in a general population sample of middle aged men. Br Med J 1990; 300: 634-8.

75. Knudsen JB, Brodthagen $U$, Gormsen $J$, Jordal $R$, Norregaard-Hansen $\mathrm{K}$, Paulev PE, Platelet function and fibrinolytic activity following distance running, scan $\mathrm{J}$ Haematol 1982; 29: 425-30.

76. Beisiegel B, Treese N, Hafner G, Meyer J, Darius $H$. Increase in endogenouos fibrinolysis and platelet activity during exercise in young volunteers. Agents Actions Suppl 1992; 37: 183-9.

77. Vind $J$, Gleerup $G$, Nielsen PT, Winther $K$. The impact of static work on fibrinolysis and platelet function. Thromb Res 1993; 72: 441-6.

78. Röcker L, Drygas WK, Heyduck B, Blood platelet activation and increase in thrombin activity following a marathon race, Eur J Appl Physiol 1986; 55: 374-80.

79. Marcella JJ, Nichols $A B$, Johnson $L L$, Owen $J$, Reison DS, Kaplan KL, Cannon PJ, Exercise-induced myocardial ischemia in patients with coronary artery disease: Lack of evidence for platelet activation or fibrin formation in peripheral venous blood, $\mathrm{J} \mathrm{Am}$ Coll Cardiol 1983; 1: 1185-93.

80. Stratton JR, Malpass TW, Ritchie JL, pfeifer MA, Harker LA. Studies of platelet factor 4 and beta thromboglobulin release during exercise: Lack of relationship to myocardial ischemia. Circulation 1982; $66: 33-43$.

81. Strauss WE, Cella G, Parisi AF, Sasahara AA, Serial studies of platelet factor 4 and beta thromboglobulin during exercise in patients with coronary artery disease, Am Heart J 1985; 10: 293-9.

82. Leon AS, Physiological interactions between diet and exercise in the etiology and prevention of ischeamic heart disease. An Clin Res 1988; 20: 114-20.

83. Marti B, Suter E, Riesen WF, Tschopp A, wanner HU. Anthropometric and lifestyle correlates of serum lipoprotein and apolipoprotein levels among normal non-smoking men and women. Atherosclerosis 1989; 75: $111-22$. 
84. Tran $Z V$, weltman A. Differential effects of exercise on serum lipid and lipoprotein levels seen with changes in body weight. JAMA 1985; 254: 919-24.

85. Blumenthal JA, Matthews $K$, Fredrikson M. Rifai $N$, Schiebolk S, German D, Steege J, Rodin J. Effects of exercise training on cardiovascular function and plasma lipid, lipoprotein, and apolipoprotein concentrations in premenopausal and postmenopausal. women. Arteriosclerosis Thromb 1991; 11: 912-7.

86. McNaughton $L$, Davies $P$. The effects of a 16 week aerobic conditioning program on serum lipids, lipoproteins and coronary risk factors. $J$ sport Med $1987 ; 27: 296-302$. 


\section{CHAPTER 2}

SUBJECTS, MATERIALS AND METHODS 


\section{SUBJECTS}

Subjects were recruited by means of advertisements in two regional newspapers and on a local radio station. Threehundred seventy people reacted and were all invited on an informational session. Subject's medical histories, physical activity levels and dietary habits, were obtained by questionnaires. Those, who suffered from any chronic disease or who participated in any sports such as running or jogging or who were active for more than one hour per week in other recreational sports, were excluded. From the remaining group, a non select sample of 26 men and 21 women was taken. After two information sessions, concerning the outline and the duration of the study, all subjects gave their written informed consent.

Thirty-four of the 47 volunteers completed the study, 20 males aged from 32 to 49 years (median= 39 years) and 14 females aged from 27 to 41 years (median= 35 years). Basic personal characteristics of the participants are shown in Table I. Some of the reasons for drop-out were mental stress $(n=2)$, injuries $(n=4)$, moving away due to change in employment $(n=2)$ and relational problems $(n=2)$. The dropout did not alter significantly the median age of the remaining group of participants. Among the remaining participants were three female and six male cigarette smokers (maximum of ten cigarettes a day), who continued to smoke during the test period. All individuals kept their diet and other living habits, like the use of alcohol, as constant as possible during the study.

\section{MATERIAL AND METHODS}

\section{Training programme}

After a medical examination, all volunteers participated in an endurance training programme, preparing for a half marathon run. Before the start of the programme, all 
Table I: Anthropometric values and contest running time of participants

\begin{tabular}{|c|c|c|c|c|c|}
\hline \multirow[b]{2}{*}{ MEN } & \multirow[b]{2}{*}{ length (m) } & \multirow[b]{2}{*}{ age $(y)$} & \multirow[b]{2}{*}{ weight $(\mathrm{kg})$} & \multicolumn{2}{|c|}{ running time (h.min.sec) } \\
\hline & & & & $15 \mathrm{~km}$ & $21 \mathrm{~km}$ \\
\hline 1 & 1.73 & 43 & 68.0 & 1.05 .33 & 1.40 .50 \\
\hline 2 & 1.73 & 40 & 77.0 & 1.11 .35 & 1.42 .39 \\
\hline 3 & 1.87 & 36 & 75.6 & 1.09 .03 & 1.42 .00 \\
\hline 4 & 1.72 & 49 & 64.0 & 1.20 .22 & 1.59 .57 \\
\hline 5 & 1.73 & 39 & 59.4 & 1.15 .03 & 1.44 .15 \\
\hline 6 & 1.80 & 32 & 83.0 & NR & 1.54 .21 \\
\hline 7 & 1.79 & 34 & 69.4 & 1.07 .28 & 1.32 .34 \\
\hline 8 & 1.82 & 35 & 72.0 & 1.07 .32 & 1.41 .15 \\
\hline 9 & 1.70 & 36 & 70.3 & 1.11 .35 & 1.42 .28 \\
\hline 10 & 1.76 & 34 & 75.0 & 1.14 .47 & 1.56 .03 \\
\hline 11 & 1.83 & 32 & 85.0 & 1.19 .06 & 2.05 .04 \\
\hline 12 & 1.87 & 32 & 79.6 & 1.06 .04 & 1.33 .02 \\
\hline 13 & 1.75 & 40 & 66.3 & 1.16 .00 & 2.07 .20 \\
\hline 14 & 1.76 & 34 & 80.1 & 1.19 .42 & 1.54 .24 \\
\hline 15 & 1.79 & 40 & 75.0 & 1.12 .52 & 1.32 .52 \\
\hline 16 & 1.87 & 39 & 74.2 & 1.07 .27 & 1.34 .50 \\
\hline 17 & 1.78 & 42 & 85.0 & 1.20 .18 & 2.01 .14 \\
\hline 18 & 1.73 & 41 & 74.5 & 1.25 .14 & 2.01 .06 \\
\hline 19 & 1.78 & 40 & 69.7 & 1.26 .42 & 1.45 .20 \\
\hline 20 & 1.82 & 40 & 86.0 & 1.09 .02 & 1.41 .50 \\
\hline \multicolumn{6}{|c|}{ WOMEN } \\
\hline 1 & 1.75 & 38 & 68.5 & 1.27 .42 & 2.20 .34 \\
\hline 2 & 1.72 & 27 & 63.0 & 1.31 .40 & 2.13 .33 \\
\hline 3 & 1.58 & 33 & 61.1 & 1.28 .10 & 1.47 .22 \\
\hline 4 & 1.78 & 32 & 70.4 & 1.22 .10 & 1.56 .58 \\
\hline 5 & 1.68 & 38 & 61.0 & 1.24 .50 & 2.00.01 \\
\hline 6 & 1.76 & 36 & 66.8 & 1.11 .35 & 2.14 .55 \\
\hline 7 & 1.57 & 33 & 52.6 & 1.15 .25 & 1.53 .06 \\
\hline 8 & 1.72 & 36 & 63.3 & 1.22 .02 & 2.04 .44 \\
\hline 9 & 1.68 & 41 & 64.4 & 1.29 .58 & 2.07 .19 \\
\hline 10 & 1.68 & 35 & 50.0 & 1.10 .47 & 1.39 .44 \\
\hline 11 & 1.60 & 28 & 57.0 & 1.19 .52 & 1.56 .35 \\
\hline 12 & 1.67 & 35 & 60.1 & 1.40 .54 & 2.14 .00 \\
\hline 13 & 1.70 & 41 & 65.2 & 1.34 .00 & 2.00 .09 \\
\hline 14 & 1.60 & 33 & 54.0 & 1.24 .16 & 1.59 .38 \\
\hline
\end{tabular}

NR $=$ no result

anthropometric tests were conducted and blood samples were taken. The training schedule was essentially the same as previously described by Janssen et al (1). The training period lasted approximately 9 months and can be divided into two periods, each terminated with a contest (Figure 1). After 24 weeks, all subjects ran a $15 \mathrm{~km}$ race, and 
after 36 weeks a half marathon run $(21.1 \mathrm{~km})$. Median (interquartile range) running time on the $15 \mathrm{~km}$ was 1.12 h.min (1.08-1.20 h.min) for the men and 1.24 h.min (1.19$1.30 \mathrm{~h} \cdot \mathrm{min})$ for the women. Median running time on the 21.1 $\mathrm{km}$ was $1.44 \mathrm{~h} . \mathrm{min}(1.41-1.58 \mathrm{~h} . \mathrm{min})$ and $2.01 \mathrm{~h} . \mathrm{min}$ (1.56$2.13 \mathrm{~h} . \mathrm{min})$ for the groups of men and women, respectively (Table 1). During the preparation period, the volunteers trained regularly 3 to 4 times a week; 6 weeks before each contest the number of training sessions was enhanced to 5-6 times a week (Table II). All training sessions were performed under professional supervision of an experienced trainer. During one of the sessions, special attention was paid to warming-up, stretching, cooling-down, and style and technique of running. The training schedule consisted of three basic elements: long-distance running, running at a higher speed (pace running) and interval training. Seventyfive - 85\% of maximal heart rate was reached during the long-distance runs, 85 - $95{ }^{\circ}$ of maximal heart rate for running at a fixed pace (over $200-2000 \mathrm{~m}$ ) and 95 - 100 8 of maximal heart rate for short-distance intervals (200 $600 \mathrm{~m})$. These three elements were present as $70 \%, 20 \%$, and $10 \%$ of the distances covered a week. The training sessions lasted maximally $60 \mathrm{~min}$. in the first part of the study and not more than $100 \mathrm{~min}$. in the second part. The purpose of this training programme was to reach a gradually undulating increase of the amount of the individual training load. Morover, the distance covered in one training session was not more than the distance of the race coming up.

\section{Blood pressure}

Blood pressure was determined by a skilled technician, after a five-minutes rest period of the subjects in supine position using a standard auscultatory method. For the systolic blood pressure the first korotkoff sounds were nated, while the diastolic blood pressure was measured at the disappearance of the Korotkoff scunds. 


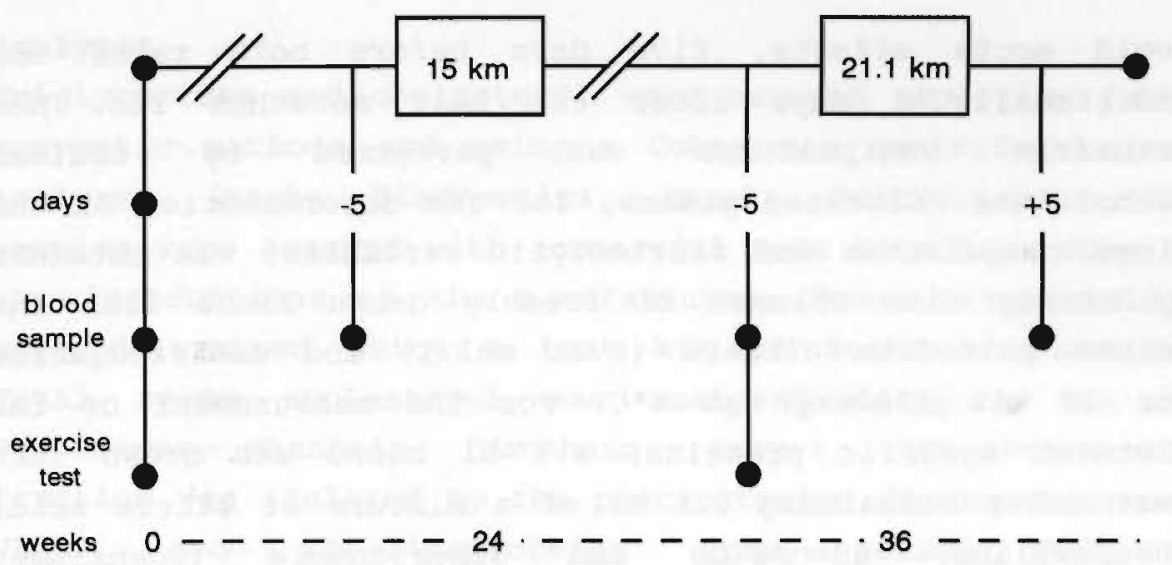

Figure 1

A schematic representation of the exercise programme.

\section{Body fat}

Percentage body fat was assessed by measuring skinfolds thickness on four sites: biceps, triceps, subscapular and supra-iliac (2).

\section{Exercise test}

Graded maximal exercise tolerance test was conducted using a Lode bicycle ergometer (Lode, Groningen, the Netherlands). The test started at a workload of 50 watt. After a warming-up period of 10 minutes, the exercise intensity was increased by 50 watt every 4 minutes until exhaustion. During the test, subjects cycled at a rate of approximately $80 \mathrm{rpm}$ and the heart rate was monitored continuously. Wmax was calculated as the power step at which was cycled for the complete 4 minutes, plus the fraction of power cycled in the final intensity step.

\section{Blood samples}

Blood samples were drawn between 8.00 and $9.00 \mathrm{am}$. All subjects were seated and had not eaten or exercised during the ten hours preceding phlebotomy. Samples were taken before the start of the training programme and, in order to 
avoid acute effects, five days before both races and additionally 5 days after the half marathon run. Non traumatic venipuncture was performed by trained technicians. Citrated plasma, for the determination of the blood coagulation and fibrinolytic variables, was obtained by mixing nine volumes of freshly drawn blood with one volume trisodium citrate $(0.11 \mathrm{~mol} / \mathrm{l})$ and centrifugation for $30 \mathrm{~min}(3000 \mathrm{xg})$ at $4^{\circ} \mathrm{C}$. For the measurement of the platelet specific proteins, $4.5 \mathrm{ml}$ blood was drawn into test tubes containing $0.5 \mathrm{ml}$ of a mixture of citric acid, theophylline, adenosine and dipyridamole (Boehringer Mannheim Corp., Mannheim, Germany). All tubes were centrifuged immediately for $30 \mathrm{~min}(3000 \mathrm{xg})$ at $4^{\circ} \mathrm{C}$. Platelet poor plasma was slowly and gently aspirated from the central part of the plasma without disturbing either the top layer or buffy coat. Within one hour from sample collection serum (for the determination of lipids and lipoproteins) and plasma were snap-frozen in aliquots and stored at $-70^{\circ} \mathrm{C}$ in plastic tubes. Immediately prior to serial analysis, test tubes were thawed at $37^{\circ} \mathrm{C}$.

Table II Training schedule of the last 6 weeks before the contests

\begin{tabular}{lcccccc}
\hline & \multicolumn{7}{l}{ number of weeks before the contest } \\
\cline { 2 - 7 } $15 \mathrm{~km}$ & 6 & 5 & 4 & 2 & 1 & 0 \\
\hline distance (km) & 45 & 22 & 20 & 45 & 28 & 10 \\
\% endurance run & 89 & 62 & 78 & 90 & 80 & 67 \\
\% interval run & 9 & 29 & 8 & 6 & 11 & 20 \\
\% speed run & 2 & 9 & 4 & 4 & 9 & 13 \\
& & & & & & \\
$1 / 2$ marathon & 65 & 50 & 35 & 70 & 55 & 25 \\
distance (km) & 87 & 76 & 71 & 80 & 69 & 72 \\
\% endurance run & 8 & 16 & 20 & 14 & 22 & 16 \\
\% interval run & 5 & 8 & 9 & 6 & 9 & 12 \\
\% speed run & & & & & & \\
\hline
\end{tabular}




\section{Analyses}

Triglycerides and cholesterol were assayed employing fully enzymatic methods and using a Cobas Bio centrifugal fast analyzer (Roche Diagnostica, Basel, Switzerland). All samples were assayed with commercial test kits according to the instructions of the manufacturer. Serum triglycerides were determined using a test kit of Roche Diagnostica. Total serum cholesterol was analyzed using a kit of Boehringer Mannheim (Mannheim, Corp.). HDL-cholesterol fraction was isolated by the precipitation of chylomicrons, VLDL- and LDL-lipoproteins from serum by the phophostungstic acid/ magnesium chloride precipitant and determined with a test kit of Boehringer (3). LDL-cholesterol was calculated according to the Friedewald equation (4). The intra-assay coefficient of variation (CV) of the tests was less than $5 \%$.

Lipoprotein(a) was measured using a commercially available enzyme-linked immunosorbent assay (ELISA) kit (TintElize lipoprotein(a) kit, Biopool AB, Umea, Sweden) (5). This assay includes ready to use micro-test plates, containing affinity purified sheep anti-apo(a) immunoglobulines and sheep anti-apo(a) peroxidase conjugated immunoglobulines. The intra-assay CV mounted 3.18 at a concentration of 150 $\mathrm{mg} / \mathrm{l}$ lipoprotein(a) and $4.8 \%$ at a concentration of $65 \mathrm{mg} / \mathrm{l}$ lipoprotein (a) .

Fibrinogen was determined by the clotting assay of Clauss (6). Reference values, determined in plasma from 50 healthy volunteers ranged from 2.0 to $4.0 \mathrm{~g} / 1$. The fibrinogen analysis showed an intra-assay $\mathrm{CV}$ of 3.28 and an interassay CV of 4.18. The von willebrand factor concentration was quantitated with an Elisa testit of Boehringer Mannheim Corp. (7). For the factor VIII:c determination an activated partial thromboplastin time (APTT) one stage clotting assay was performed, using a factor deficient plasma from Behring (Marburg, Germany) (8). The cvs obtained for von willebrand factor were 3.48 for the intra-assay variation and 6.78 
for the interassay variation, for the factor VIII:c determinations CVS of $3.7 \frac{8}{8}$ and 6.18 were found. Thrombinantithrombin III was determined with an ELISA kit of Behring Corporation (9). Reference values, determined in plasma of 50 healthy volunteers were $1.0-4.1 \mu \mathrm{g} / 1$. For thrombin-antithrombin III the intra-assay and interassay coefficients of variation were $5.1 \%$ and $7.4 \%$, respectively. Tissue-plasminogen activator antigen ( $t-P A)$ concentrations and $\mathrm{D}$-dimer concentrations were determined in plasma by an ELISA method according to the instructions of the manufacturer (Kabi Vitrum Diagnostica, Mölndal, Sweden and Boehringer Mannheim Corp., respectively) $(10,11)$. Intraassay $C V$ was less than $5 \%$ for both assays. Plasminogen activator inhibitor (PAI) activity was analyzed with a commercial test kit from Kabi Vitrum Diagnostica (Mölndal, Sweden), using excess single chain $t-P A$ and $s-2251$ as chromogenic substrate for plasmin (12). PAI activity is expressed in arbitrary units times $10^{3}$ per 1 (AU.10 $/ 1$ ); 1 $\mathrm{AU}$ equals the amount of PAI that neutralizes 1 IU of $t-\mathrm{PA}$ under conditions instructed. Intra-assay coefficient of variation was less than $10 \%$. Reference ranges, determined in plasma of 50 healthy volunteers (males and females) wexe for $t-P A: 0.9-12.1 \mu \mathrm{g} / 1$ and for PAI: 10.7 - 32.7 $\mathrm{AU} .10^{3} / 1$. The $\mathrm{D}$-dimer reference values ranged from 37 to 373 $\mu \mathrm{g} / 1$ for males and from 38 to $438 \mu \mathrm{g} / 1$ for females.

Plasma platelet factor 4 and beta-thromboglobulin concentrations were determined by an ELISA method according to the instructions of the manufacturer (Boehringer Mannheim Corp., Mannheim, Germany) (13). Platelet factor 4 and beta-thromboglobulin standards were standardized against the First National Standards, $83 / 505$ and $83 / 501$ respectively. Intra-assay $C V$ was between 5-108 for both assays.

\section{statistics}

All statistical computations were done with SPSS/PC+ 
Statistics 4.0 computer package (14). Wilcoxon signed rank test was used to compare differences in pre- and postexercise blood samples. The Mann-Whitney Wilcoxon test was used to compare the male and female population. Correlations between changes in lipids, lipoproteins and haemostatic factors and changes in anthropometric values were calculated according to the method of spearman. 


\section{REPERENCES}

1. Janssen GME. Marathon running: functional changes in male and female subjects during training and contests. Int J Sports Med 1989; 10 (suppl 3): 117-90.

2. Durnin J7GA, Womersley J. Body fat assessed from total body density and its estimation from skinfold thickness: measurements on 481 men and women aged from 16 to 72 years. Br J Nutx $1974 ; 32$ : 77-97.

3. Seigler L, Wu WT. Separation of serum high-density lipoprotein for cholesterol determination:

ultracentrifugation vs precipitation with sodium phosphotungstate and magnesium chloride. Clin Chem 1981; 27: 838-41.

4. Friedewald WT, Levy RI, Frederickson DS. Estimation of the concentration of low-density-lipoprotein cholesterol in plasma without use of the preparative ultracentrifuge. Clin Chem 1972; 18: 499-509.

5. Brändstorm $A$, Johnson $O$, Dahlen $G$, Ranby $M$. $L p(a)$ levels in a healthy population measured by a new enzyme linked immuno sorbent assay (abstract). Thromb Haemost $1989 ; 62$ : 573 .

6. De Metz $M$, van Wersch JWJ. Use of a centrifugal analyzer for a chromogenic prothrombin time, a chromogenic activated partial thromboplastin time and a kinetic fibrinogen assay in a routine hospital laboratory. Haemostasis $1987 ; 17$ : 254-9.

7. Silveira AMV, Yamamoto $T$, Adamson $L$, Hessel $B$, Blomback B. Application of an enzyme-linked immunosorbent assay (ELISA) to von Willebrand factor (VWF) and its derivatives. Thromb Res 1986: 43: 91102.

8. Ponjee GAE, vader HL, De Wild PJ, Janssen GWT, Van der Graaf F. One-step chromogenic equivalent of activated partial thromboplastin time evaluated for clinical application. Clin Chem 1991; 37: 1235-44.

9. Enzygnost TAT ELISA test kit. Enzyme immunoassay for the determination of thrombin/antithrombin III complex. Behringwerke AG, Marburg, Germany, 1988.

10. Rijken DC, Juhan-Vague I, Decock F, Collen D. Measurement of human tissue-type plasminogen activator by a two-site immunoradiometric assay. J Lab Clin Med 1983; 101: 274 .

11. Admiral JV, Plassart $F$, Minard. Measurement and clinical relevance of $D$-dimer by ELISA. Presentation at the Fibrinogen Workshop Giessen G. May 21-24 1986.

12. Chmielewska J, Wiman B. Determination of tissue plasminogen activator and its 'fast' inhibitor in plasma. Clin Chem 1986; 32: 482-5.

13. Pepper DS. Radioimmunoassay of platelet proteins. In: Patrono C, Pesker BA, eds., Handbook of experimental pharmacology. Springer-verlag 1987; 82: 517-41.

14. Norusis MJ/SPSS Inc. SPSS/PC+ 4.0 base manual for the 
IBM $\mathrm{PC} / \mathrm{XT} / \mathrm{AT}$ and $\mathrm{PS} / 2$. SPSS InC, Chicago, IL, USA 1990. 


\section{CHAPTER 3}

EFFECTS OF LONG-TERM EXERCISE OF MODERATE INTENSITY ON ANTHROPOMETRIC VALUES AND SERUM LIPIDS AND LIPOPROTEINS

G.A.E. Ponjee, G.M.E. Janssen, J. Hermang and J.W.J. van Wersch

Accepted in:

European Journal of Clinical Chemistry and Clinical Biochemistry 


\section{SUMRARY}

The influence of endurance training on serum lipids and lipoproteins was investigated in 20 sedentary males and 14 sedentary females. The total group was trained 3 to 4 times a week for 9 months. After 24 weeks all subjects ran a 15 $\mathrm{km}$ race and after 36 weeks a half marathon $(21 \mathrm{~km}$ ) race. Anthropometric values were determined before and after the training programme. Blood samples were drawn before the start of the training programme and, in order to avoid the measurement of acute effects, 5 days before both races. In the male group, median body weight and body mass were significantly decreased ( $p<0.01$ ) after nine months of training, while percentage body fat, was significantly decreased in both groups. During the training period, median serum total cholesterol, low density lipid cholesterol and triglyceride concentrations decreased significantly $(p<0.01)$ in the male group, but not in the female population. The changes in serum lipids or lipoproteins did not correlate significantly with changes in body weight, body mass index or percentage body fat. Stepwise multiple regression showed that these changes were mostly dependent on initial serum levels. Finally, no significant increase in median high density lipid cholesterol was observed in either the male or female group.

In conclusion, the results from our study demonstrate that prolonged physical conditioning of moderate intensity has beneficial effects on lipid and lipoprotein concentrations of male runners, but does not essentially influence lipid and lipoprotein profiles in female runners. 


\section{INTRODUCTION}

Coronary heart disease is a serious health problem in most western countries (1). Although the precise etiology of coronary heart disease still needs to be elucidated, a contributing role for elevated serum lipids and lipoproteins has been established. In both men and women total cholesterol, low density lipoprotein cholesterol. (LDL-cholesterol) and triglycerides are positively correlated to the risk of coronary heart disease, while high density lipoprotein cholesterol (HDL-cholesterol) is inversely related $(2,3,4)$. In order to manipulate lipoprotein levels, life-style intervention may be attempted prior to pharmacotherapy $(5,6,7)$. It has been suggested that exercise may protect against ischemic heart disease, partly through effects on plasma lipids and lipoproteins $(7,8,9,10)$. Cross-sectional studies, comparing endurance trained athletes to sedentary individuals, generally have shown lower levels of triglycerides, total cholesterol and LDL-cholesterol and higher levels of HDLcholesterol in sera of the trained subjects $(11,12,13)$. However the athletes concerned were often involved in vigorous training programmes, so the results of these studies may be biased due to self-selection of physically active subjects $(11,13)$. Less intensive physical conditioning may be more appropriate to elicit long-term improvement in plasma lipoprotein profiles for a large population. Longitudinal studies of individuals exercising on recreational basis have yielded less marked results, which are often equivocal due to confounding factors like length of the training period, intensity and form of the training programme and diet or weight loss of the individuals under investigation (14-20). Furthermore, most of these studies are restricted to either exercising males or - to a far lesser extent - exercising females (17-20). The present study is designed to investigate the effects of 
a prolonged training programme of moderate intensity on the lipid status in a group of previously sedentary males and females, while keeping other habitual factors constant.

\section{MATERIAL AND METHODS}

\section{Subjects}

Threehundred seventy people replied to advertisements in two local newspapers and on a local radio station. Those who participated in any sports such as running or jogging or who were active for more than one hour per week in other recreational sports were excluded. From the remaining group, 47 individuals were aselectly chosen to participate in the study. Thirty-four of the 47 participants fulfilled the study, 20 males aged from 32 to 49 years (median:39 years) and 14 females aged from 27-41 years (median: 35 years). No lipid lowering or antibypertensive medication was used by any of the volunteers. Among the participants were three female and six male cigarette smokers (maximum of ten cigarettes a day), who continued to smoke during the test period. All individuals kept their diet and other living habits, like the use of alcohol as constant as possible during the study. After two information sessions all subjects gave their written informed consent.

\section{Training programe}

After a medical examination and pre-exercise control measurements, all volunteers participated in a 9 month endurance training programme preparing for a half marathon run $(21 \mathrm{~km})$. The schedule was essentially the same as previously described by Janssen et al (21). The training period lasted 9 months. After 24 and 36 weeks of training, all subjects ran a $15 \mathrm{~km}$ and $21 \mathrm{~km}$ race, respectively. During the general preparation period the volunteers trained 3-4 times a week; 6 weeks before each contest the training programme was intensified to 5-6 times a week. 
Beside the attention paid to style and technique of running, stretching, speed, intervals, warming-up and cooling-down, the training included three elements: longdistance running, running at high speed and interval training.

\section{Blood samples}

All blood samples were drawn between 8.00 and 9.00 am. All subjects were seated and had not eaten or exercised during the preceding ten hours before phlebotomy. Samples were taken before the start of the training programme and, in order to avoid acute effects, five days before both races. Non-traumatic venipuncture was performed by trained technicians. Within one hour from sample collection serum was separated from blood, snapfrozen in aliquots, stored at $-70^{\circ} \mathrm{C}$ in plastic tubes and thawed at $37^{\circ} \mathrm{C}$ immediately prior to serial analysis.

\section{sethods}

Percentage body fat was assessed by measuring skinfold thickness on four sites: biceps, triceps, subscapular and supra-iliac (22). Triglycerides and cholesterol were assayed employing fully enzymatic methods and using a cobas Bio centrifugal fast analyzer (Roche Diagnostica, Basle, Switzerland). All samples were assayed with commercial test kits according to the instructions of the manufacturer. serum triglycerides were determined using a test kit of Roche Diagnostica. Total serum cholesterol was analyzed using a kit of Boehringer Mannheim (Mannheim, Germany). $\mathrm{HDL}$-cholesterol fraction was isolated by the precipitation of chylomicrons, very low density lipoprotein (VLDL) - and LDL-cholesterols from serum by the phophostungstic acid/ magnesium chloride precipitant and determined with a test kit of Boehringer (23). LDL-cholesterol was calculated according to the Friedewald equation (23). The intra-assay coefficient of variation of the tests was less than $5 \%$. 


\section{statistics}

All statistical computations were done with SPSS/PC+ 4.0 computer package (SPSS Inc., Chicago, USA). Wilcoxon signed rank test was used to compare differences in pre- and postexercise serum samples. The Mann-Whitney Wilcoxon test was used to compare the male and female population. All data are given as medians and interquartile ranges. Correlations between changes in lipids and lipoproteins and changes in anthropometric values were calculated according to the method of spearman. Stepwise multiple regression was carried out to find independent determinants for the change in total cholesterol and triglycerides.

\section{RESULTS}

\section{Effect of training on anthropometric values}

Table I shows median (interquartile range) body weight, body mass index and percentage body fat before and after the training programme in the male and female group. Both men and women experienced a weight reduction. In the male group the median post-training body weight and body mass index was significantly lower than the median pre-training values $(p<0.01)$. In both male and female group a significant reduction of percentage body fat was noticed $(\mathrm{p}<0.01)$.

\section{Effect of training on serum lipids and lipoproteins}

Median (interquartile range) serum triglycerides, total cholesterol, LDL-cholesterol and HDL-cholesterol of the male and female group prior to the training programme, 5 days before the $15 \mathrm{~km}$ and $21 \mathrm{~km}$ race, respectively, and the changes after nine months of training, are shown in Table I and Figure 1 . A significant reduction of the median triglycerides concentration at the end of the training programme in comparison to pre-training levels $(p<0.01$ ) was only observed in the male group. Furthermore, only in the 


\section{TABLE I}

Median (interquartile range) body weight, weight body mass index (BMI) and percentage body fat of the male $(N=20)$ and female $(N=14)$ group before and after the training programme.

\begin{tabular}{|c|c|c|c|c|}
\hline & gender & before & after & $\begin{array}{l}\text { P-value } \\
\text { before vs. after }\end{array}$ \\
\hline weight & male & $74.6(69.1-79.8)$ & $72.2(64.9-77.7)$ & $p<0.001$ \\
\hline (kg) & female & $63.0(57.0-65.8)^{9}$ & $60.7(55.0-63.4)^{s}$ & $p=0.10$ \\
\hline BMI & male & $23.1(21.6-25.5)$ & $22.0(21.1-24.4)$ & $p=0.001$ \\
\hline$\left(\mathrm{kg} \cdot \mathrm{m}^{-2}\right)$ & female & $21.6(21.3-22.6)^{55}$ & $21.5(21.3-22.3)$ & $p=0.14$ \\
\hline body fat & male & $19.2(16.2-24.0)$ & $14.1(11.1-15.5)$ & $p=0.002$ \\
\hline (\%) & female & $27.1(24.3-30.5)^{s}$ & $24.3(20.7-26.7)^{s}$ & $p=0.003$ \\
\hline
\end{tabular}

"Males vs. females: $p<0.01, " p<0.05$

male group the median TC concentration decreased significantly during the training period $(p<0.01)$, together with a significant reduction in LDL-cholesterol $(p<0.01)$. Neither in the male nor female population HDL- cholesterol changed significantly during the test period. The median serum HDL-cholesterol concentration in the female group remained significantly higher in comparison to the median serum HDLC in the male group $(p<0.05)$.

\section{Correlation analysis of serum lipids and lipoproteins}

Table III shows the coefficients of correlation (spearman) between the changes in body weight, BMI and percentage body 
fat and the changes in serum lipids and lipoproteins for the total group. These findings did not show a significant correlation between reductions in body weight and changes in serum lipids or lipoproteins.

\section{Multiple regression}

In the multiple regression model, dependent variabeles were the change in total cholesterol (s total cholesterol) and the change in triglycerides ( $\Delta$ triglycerides). Independent variables for $\Delta$ total cholesterol were: age, sex, change in body weight ( $\Delta$ weight), change in body mass index ( $\Delta$ body mass index), $\Delta$ triglycerides and total cholesterol level before the training programme (total cholesteroll) $\left(R^{2}=0.621, F=6.83, p<0.001 ; N=32\right)$. Independent variabeles for $\Delta$ triglycerides were: age, sex, change in body weight ( $\Delta$ weight), change in body mass index ( $\Delta$ body mass index) and triglyceride level before the training programme (triglycerides1) $\left(R^{2}=0.437, F=4.03, p<0.01 ; N=32\right)$. In the stepwise multiple regression for $\Delta$ total cholesterol and $\Delta$ triglycerides in the total group, the highest correlation was found with the initial total cholesterol and triglycerides levels: $R^{2}=0.57$ and 0.36 , respectively; Figure 2 shows the correlation between $\Delta$ total cholesterol and total cholesterol levels. For $\Delta$ total cholesterol no other variabeles were selected. Excluding the triglycerides 1 level in the stepwise model, an independent predictor of the variance in the $\Delta$ triglycerides was $\Delta$ weight $\left(R^{2}=0.21\right)$. 
TABLE II Median (interquartile range) lipid and lipoprotein concentrations in sera of males $(N=20)$ and females $(N=14)$ prior to the training programme and 5 days before the $15 \mathrm{~km}$ and $21 \mathrm{~km}$ race, respectively.

\begin{tabular}{|c|c|c|c|c|c|c|}
\hline & \multirow[b]{2}{*}{ gender } & \multirow[b]{2}{*}{ before } & \multirow[b]{2}{*}{$15 \mathrm{~km}$} & \multirow{2}{*}{$21 \mathrm{~km}$} & \multicolumn{2}{|c|}{ p-value } \\
\hline & & & & & before vs. $15 \mathrm{~km}$ & before vs. $21 \mathrm{~km}$ \\
\hline TG & M & $1.11(0.91-1.51)$ & $0.93(0.82-1.35)$ & $0.92(0.77-1.36)$ & $p=0.08$ & $p=0.001$ \\
\hline$(\mathrm{mmol} / 1)$ & $\mathrm{F}$ & $0.89(0.65-1.14)^{39}$ & $0.87(0.79-1.34)$ & $0.73(0.57-1.11)$ & $p=0.14$ & $p=0.28$ \\
\hline TC & $M^{*}$ & $5.80(5.00-6.40)$ & $5.20(4.70-5.60)$ & $5.10(4.45-5.70)$ & $p<0.001$ & $p<0.001$ \\
\hline$(\mathrm{mmol} / \mathrm{l})$ & $\mathrm{F}$ & $5.30(3.90-6.00)$ & $5.00(4.60-5.80)$ & $4.90(4.70-5.50)$ & $p=0.38$ & $p=0.16$ \\
\hline HDLC & $M$ & $1.00(0.90-1.25)$ & $1.00(0.90-1.10)$ & $1.00(0.95-1.10)$ & $p=0.51$ & $p=0.75$ \\
\hline$(\mathrm{mmol} / \mathrm{l})$ & $\mathrm{F}$ & $1.45(1.05-1.85)^{49}$ & $1.40(1.20-1.80)^{3}$ & $1.40(1.10-1.60)^{s s}$ & $p=0.97$ & $p=0.18$ \\
\hline LDLC & $M^{\circ}$ & $3.98(3.32-4.81)$ & $3.59(3.14-4.15)$ & $3.48(3.13-4.13)$ & $p=0.01$ & $p=0.001$ \\
\hline$(\mathrm{mmol} / \mathrm{l})$ & $F$ & $3.18(2.49-3.92)^{31}$ & $3.05(2.57-3.39)^{15}$ & $3.28(2.67-3.80)$ & $p=0.15$ & $p=0.22$ \\
\hline
\end{tabular}

- TG = triglycerides; TC = total cholesterol; HDLC = high density lipoprotein cholesterol; LDLC = low density lipoprotein cholesterol.

- "Males vs. females: $p<0.01$, " $p<0.05$

$-\cdot N=19$ 


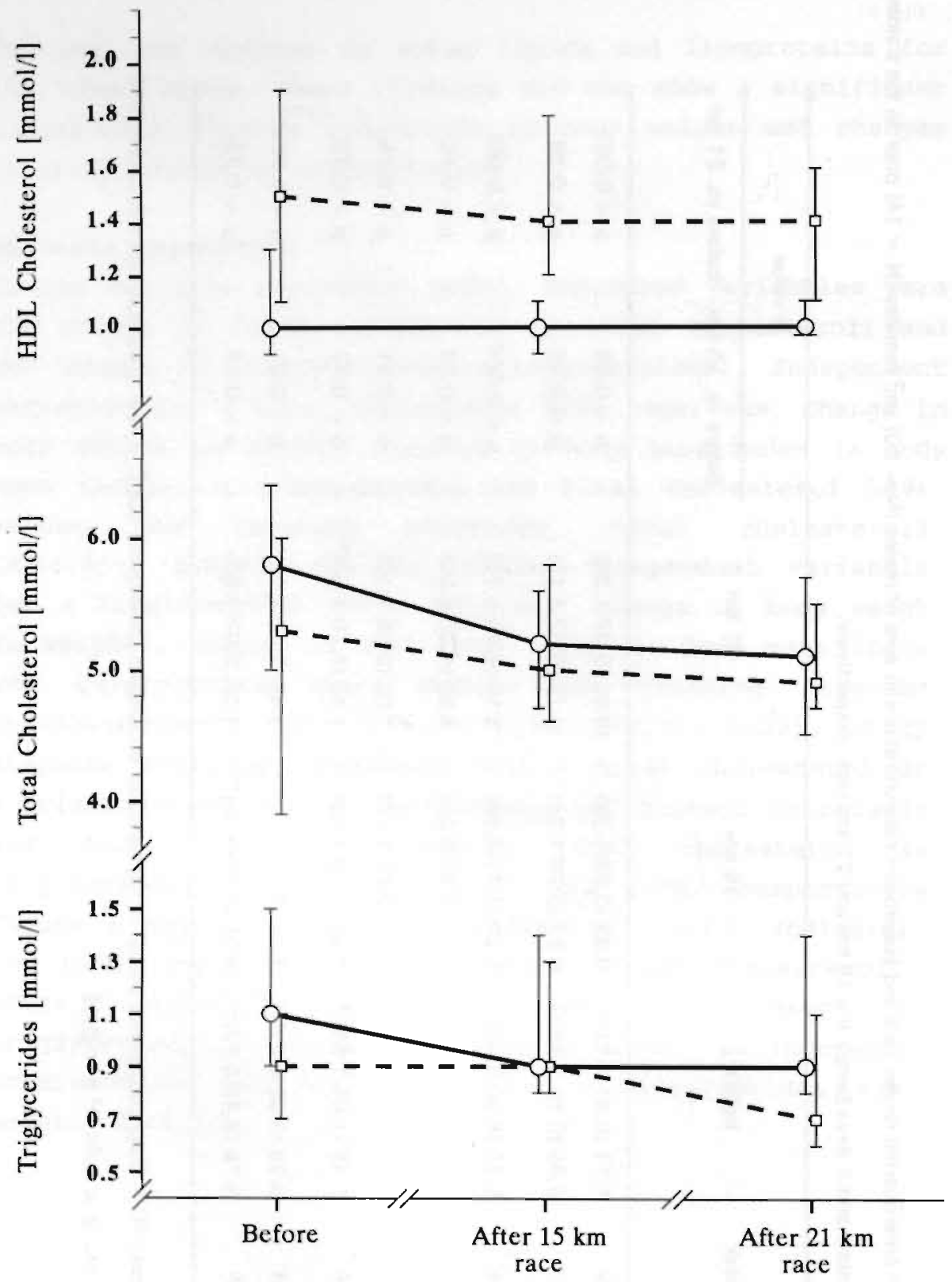

Figure 1

Median (interquartile range) serum TG, TC and HDLC in 20 men (O) and 14 women (D) before the trainingsprogramme, and 5 days before the $15 \mathrm{~km}$ and $21 \mathrm{~km}$ race respectively. 
TABLE III

Correlation (Spearman) between changes $(\Delta)$ in serum lipids, lipoproteins and changes in anthroprometic values after nine months of training $(N=34)$

\begin{tabular}{lcccc}
\hline & $\Delta$ LDLC & $\Delta$ TC & $\Delta$ HDLC & $\Delta$ TG \\
\hline$\Delta$ weight & 0.08 & 0.04 & 0.12 & 0.41 \\
$\Delta$ BMI & 0.08 & 0.04 & 0.15 & 0.40 \\
$\Delta$ bodyfat* & 0.43 & 0.40 & 0.35 & 0.00 \\
\hline
\end{tabular}

TG = triglycerides; TC $=$ total cholesterol; HDLC $=$ high density lipoprotein cholesterol; LDLC = low density lipoprotein cholesterol.

- 13 missing values

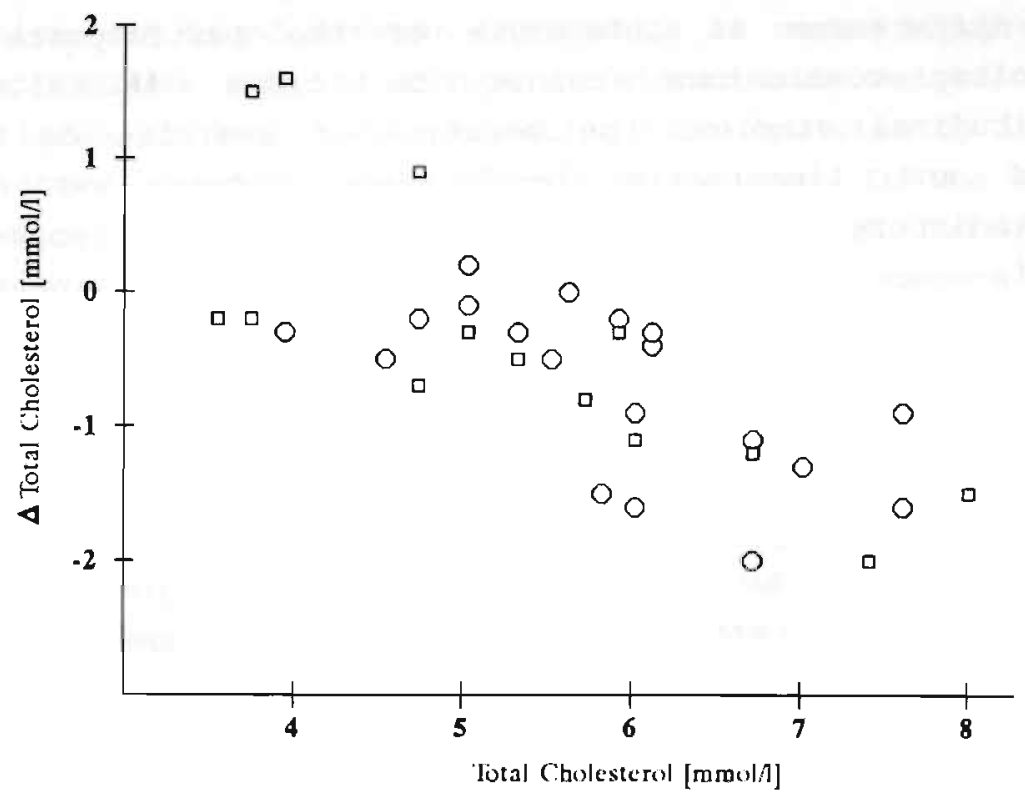

Figure 2

Correlation between the initial cholesterol level (TC) and the changes in total cholesterol ( $\triangle \mathrm{TC}$ ) after nine months of training in sera of 20 men (o) and 14 women (u). 


\section{DIScussION}

Elevated levels of triglycerides, total cholesterol and its principal carrier LDL-cholesterol, constitute a major risk factor for cardiovascular disease, while HDL-cholesterol has an inverse relationship with coronary heart disease $(2,3,4)$. Many exogenous factors influence lipid and lipoprotein concentrations, like diet, body composition, alcohol consumption and medication $(5,6,7,25)$. Prolonged exercise may have favourable effects on plasma lipids and lipoproteins and therefore constitute a non-pharmacological approach to lipoprotein therapy $(5,7,9,10)$. Cross-sectional studies have shown that endurance athletes generally have lower levels of triglycerides, total cholesterol and LDLcholesterol and higher levels of HDL-cholesterol $(11,12,13,26)$. However, crosssectional studies have methodological limitations because of genetic differences and differences in life-style of the participants and definite conclusions cannot be drawn $(11,13)$. In longitudinal studies, the benefits of exercise on blood lipid and lipoprotein levels are modest and often contradictory (14-18). The changes in serum lipoprotein levels seem to be dependent on the duration and intensity of the training programme and whether or not weight is lost concomitantly $(14,17,26,27)$. In our study, although all individuals maintained their usual diet, both men and women lost body weight and body fat, mainly caused by an increased energy expenditure due to the more active lifestyle. Because the decrease in body weight and body mass index was not significant in the female group, a reduction in skinfold thickness pointed toward a redistribution of body fat or replacement of fat tissue to muscle tissue due to the training regimen (18). In general, the present long-term exercise programme affected blood lipids more in men than in women. In the female group, the 9 months aerobic endurance exercise programme induced only 
small and statistically non-significant changes in serum lipid or lipoprotein levels. These findings are consistent with results of other longitudinal studies that failed to demonstrate improved lipid profiles among female exercisers (18,28-31). However, the investigation of the independent effect of exercise in women is complicated because of the influence of reproductive hormones on serum lipids (18,29,31). Furthermore, the number of women under investigation in this study could have been too small to find marginal changes statistical significant. In the male group, the significant decrease of total cholesterol, also observed in other longitudinal studies $(14,26,32-34)$, was mainly attributed to the decrease in LDL-cholesterol since HDLcholesterol remained essentially unchanged. Some studies showed that the reduction in serum total cholesterol and LDL-cholesterol is mainly caused by the exercise induced weight loss (35). However, in this study no significant relation was found between the change in serum lipoprotein concentrations and the change in either body weight, body mass index or body fat, suggesting that exercise by itself influenced serum cholesterol concentrations. In one study in which four different diets were compared during an exercise programme, it was concluded that physical activity rather than diet is responsible for alterations in VLDL-LDL cholesterol, but that the amount of cholesterol intake is an important factor for an increase in HDL-cholesterol (27). During the training programme, the subjects in our study maintained their dietary intake as unaltered as possible, which could explain the fact that no change in HDI-cholesterol was observed for the individuals in the present study. In other studies a modest exercise induced increase in HDL-cholesterol was observed, which was mainly caused by an increase in HDL-cholesterol-2 $(20,32,34,36)$. The elevated HDL-cholesterol levels in the sera of the female participants in comparison to $\mathrm{HDL}$ levels of the male runners, is a well known finding, which is, apart from 
differences in steroid hormones, attributed to differences in body fat distribution and waist-to-hip ratio between both sexes $(25,37)$. In the present study, median serum triglyceride concentrations decreased significantly in the male group together with a non-significant reduction in the female group during the course of the nine months test period. The reduction in serum triglycerides did not correlate significantly with the reduction in body weight, body mass index or percentage body fat after nine months. Furthermore, multiple regression analysis revealed that the fall in serum triglycerides was, like the fall in serum total cholesterol, mostly dependent on intial serum levels prior to the exercise programme. These findings support the view that exercise by itself and not only weight loss through exercise influences lipid and lipoprotein levels.

In conclusion, the results of the present study demonstrate that a nine months training programme of moderate intensity improves lipid and lipoprotein profiles in male runners towards a reduced risk profile for cardiovascular disease, but has only minimal influence on lipid and lipoprotein levels in female runners. 


\section{REFERENCES}

1. Nieman DC, Fitness and sports Medicine. An introduction. Bull Publishing Company, Palo Alto $\mathrm{Ca}$, USA 1990.

2. Rhoads GG, Gulbrandsen CL, Kagan A. Serum lipoproteins and coronary heart disease in a population study of Hawaii Japanese men. N Engl J Med 1976; 294: 293-8.

3. Gordon $T$, Castelli WP, Hjortland MC, Kannel WB, Dawber TR. High density lipoprotein as a protective factor against coronary heart disease: the Framingham study. Am J Med 1977; 62: 707-14.

4. Criqui MH, Heiss MPHG, Cohn $R$, Cowan LD, Suchindran $C M$, Bangdiwala $S$ et al. Plasma triglyceride level and mortality from coronary heart disease. $N$ Engl $J$ Med $1993 ; 328: 1220-5$.

5. Wood PD, Stefanick ML, Dreon DM, Frey-Hewitt B, Caray SC. Changes in plasma lipids and lipoproteins in overweight men during weight loss through dieting as compared with exercise. $N$ Engl $J$ Med 1998; 319: 11739.

6. H申stmark AT, Berg J, Brudal S, Berge SR, Kierulf $P$, Bjerkdal $T$. Coronary risk factors in middle-aged men as related to smoking, coffee intake and physical activity. Scand J Soc Med 1992; 4: 196-203.

7. Leon AS. Physiological interactions between diet and exercise in the etiology and prevention of ischaemic heart disease. Ann Clin Res 1988; 20: 114-20.

8. Paffenbarger RS, Hyde RT, wing AL, Hsieh C. Physical activity, all-cause mortality, and longevity of college alumni. N Engl J Med 1986; 314: 605-13.

9. Ekelund L-G, Haskell WL, Johnson JL, Whaley FS, Criqui MN, Sheps DS. Physical fitness as a predictor of cardiovascular mortality in asymptomatic North American men. N Engl J Med 1998; 319: 1379-84.

10. Sandvik L, Erikssen J, Thaulow E, Erikssen G, Mundal $R$, Rodahl $K$. Physical fitness as a predictor of mortality among healthy, middle-aged Norwegian men. $\mathbf{N}$ Engl J Med 1993; 328: 533-7.

11. Mena P, Maynar M, Campillo JE. Plasma lipid concentrations in professional cyclists after competitive cycle races. Eur J Appl Physiol 1991; 62: $349-52$.

12. Northcote RJ, Canning GC, Todd IC, Ballantyne D. Lipoprotein profiles of elite veteran endurance athletes. Am J Cardiol 1988; 61: 934-6.

13. Stray-Gundersen J, Denke MA, Grundy SM. Influence of lifetime cross-country skiing on plasma lipids and lipoproteins. Med Sci Sports Exerc 1991; 23: 695-702.

14. Després JP, Tremblay A, Moorjani S, Lupien PJ, Thériault G. Nadeau A, Bouchard C. Long-term exercise training with constant energy intake. 3: Effects on plasma lipoprotein levels. Int J Obesity 1990; 14: 85- 
94.

15. Thompson PD, Cullinane EM, Sady SP, Flynn MM, Bernier DN, Kantor MA, Saritelli AC, Herbert PN. Modest changes in high-density lipoprotein concentration and metabolism with prolonged exercise training. Circulation 1988; 78: 25-34.

16. Superko HR. Exercise training, serum lipids, and lipoprotein particles: is there a change threshold? Med Sci Sports Exerc 1991; 23: 677-85.

17. Raz I, Rosenblit H, Kark JD. Effect of moderate exercise on serum lipids in young men with low high density lipoprotein cholesterol. Arteriosclerosis 1988; 8: 245-51.

18. Blumenthal JA, Matthews $K$, Frederikson $M$, Rifai $N$, Schniebolk S, German D, steege J, Rodin J. Effects of exercise training on cardiovascular function and plasma lipid, lipoproteins, and apoliproprotein concentrations in premenopausal and postmenopausal women. Arteriosclerosis Thromb 1991; 11: 912-7.

19. Findlay IN, Taylor RS, Dargie HJ, Grant S, pettigrew $\mathrm{AR}$ et al. Cardiovascular effects of training for a marathon run in unfit middle aged men. Br Med J 1987; 295: 521-4.

20. Aellen $R$, Hollmann $W$, Boutellier U. Effects of aerobic and anaerobic training on plasma lipoproteins. Int $J$ Sport Med 1993; 14: 396-400.

21. Janssen GME. Marathon running: functional changes in male and female subjects during training and contests. Int J Sports Med 1989; 10 (suppl 3): 117-90.

22. Durnin JVGA, Womersley J. Body fat assessed from total body density and its estimation from skinfold thickness: measurements on 481 men and women aged from 16 to 72 years. Br J Nutr 1974; 32: 77-97.

23. Seigler L, Wu WT. Separation of serum high-density lipoprotein for cholesterol determination: ultracentrifugation vs precipitation with sodium phosphotungstate and magnesium chloride. Clin Chem 1981; 27: 838-41.

24. Friedewald WT, Levy RI, Frederickson DS. Estimation of the concentration of low-density-lipoprotein cholesterol in plasma without use of the preparative ultracentrifuge. Clin Chem 1972; 18: 499-509.

25. Marti B, Suter E, Riesen WF, Tschopp A, wanner $\mathrm{H}-\mathrm{U}$. Anthropometric and lifestyle correlates of serum lipoprotein and apolipoprotein levels among normal non-smoking men and women. Atherosclerosis 1989; 75: 111-22.

26. Williams PT. Weight set-point theory predicts HDLcholesterol levels in previously obese long-distance runners. Int $\mathrm{J}$ obe $1990 ; 14: 421-7$.

27. Ekstedt $B$, Jönsson $E$, Johnson $O$. Influence of dietary fat, cholesterol and energy on serum lipids at vigorous physical exercise. Scand $J$ Clin Lab Invest 
1991: 51: 437-42.

28. Perry AC, Shaw MH, Hsia $L$, Nash MS, Kaplan $T$, Signorile JF. Plasma lipid levels in active and sedentary premenopausal females. Int $J$ sports Med 1992; 13: 210-5.

29. Taylor PA, ward A. Women, high density lipoprotein cholesterol, and exercise. Arch Intern Med 1993; 153: $1178-84$.

30. McNaughton L, Davies P. The effects of a 16 week aerobic conditioning program on serum lipids, lipoproteins and coronary risk factors. J sports Med $1987 ; 27: 296-302$.

31. Moll ME, Williams RS, Lester RM, quartfordt SH, wallace AG. Cholesterol metabolism in non-obese women. Atherosclerosis 1979 ; 34 : 159-66.

32. Hespel P, Lijnen P, Fagard R, Van Hoof R, Rossenen $M$. Amery A. Changes in plasma lipids and apoprotein associated with physical training in middle-aged sedentary men. Am Heart J 1988; 115: 786-92.

33. Mendoza SG, Carrasco H, Zerpa A, Briceno Y, Rodriquez F. Speirs J, Glueck CJ. Effect of physical training on lipids, lipoproteins, apolipoproteins, lipases, and endogenous sex hormones in men with premature myocardial infarction. Metabolism 1991; 40: 368-77.

34. Rönnemaa T, Marniemi J, Puukka P, Kuusi T. Effects of long-term physical exercise on serum lipids. Lipoprotein and lipid metabolizing enzymes in type 2 (non-insulindependent) diabetic patients. Diabetes Res $1988 ; 7: 79-84$.

35. Tran $\mathrm{ZV}$, weltman A. Differential effects of exercise on serum lipid and lipoprotein levels seen with changes in body weight. A meta-analysis. JAMA 1985; $254: 919-24$.

36. Williams PT, Krauss RM, Vranizan KM, wood PDS. Changes in lipoprotein subfractions during diet-induced and exercise-induced weight loss in moderately overweight men. Circulation 1990; 81: 1293-1304.

37. Freedman DS, Jacobsen SJ, Barboriak JJ, Sobocinsky KA, Anderson AJ. Body fat distribution and male/female differences in lipids and lipoproteins. Circulation 1990; 81: 1498-1506. 


\section{CHAPTER 4}

LONG-TERM PHYSICAL EXERCISE AND LIPOPROTEIN(a)

LEVELS IN A PREVIOUSLY SEDENTARY MALE AND FEMALE

POPULATION

G.A.E. Ponjee, G.M.E. Janssen, and J.พ.J. van Wersch

Also published in:

Annals of Clinical Biochemigtry 1995; 32: 1-5.

(Reproduced with permission) 


\section{SUMMARY}

Lipoprotein(a) is considered to be an independent risk factor for cardiovascular disease. Because exercise has a potentially beneficial effect on the development of atherosclerosis, this study was designed to investigate the effect of long-term physical exercise on lipoprotein(a) levels. For this purpose 20 sedentary males and 14 sedentary females were trained 3 to 4 times a week with increasing intensity during nine months. After 24 weeks all subjects ran a $15 \mathrm{~km}$ race and after 36 weeks a half marathon run $(21 \mathrm{~km})$. Blood samples were drawn before the training programme, 5 days before both races and 5 days after the half marathon run. Median (interquartile range) pre-training values in the male group were 32 (11-63) $\mathrm{mg} / \mathrm{l}$ and in the female group 65 (23-199) $\mathrm{mg} / 1$. After 24 weeks of training median (interguartile range) serum lipoprotein(a) concentrations were elevated significantly in the male group $(p<0.05)$ and in the female group $(p<0.01)$. Moreover, after 36 weeks of training, in preparation for the half marathon competition, median lipoprotein(a) levels had risen almost two-fold in both groups $(p<0.01)$ and were still elevated five days after the half marathon run. In conclusion, the results of this study demonstrate that an exercise programme which includes running of increasing distances significantly increases serum lipoprotein(a) levels. 


\section{INTRODUCTION}

Lipoprotein (a), first described by Berg in 1963, is a complex macromolecule assembled from two different components(1). Lipoprotein(a) comprises a low density lipoprotein moiety, containing an apolipoprotein $B$ subunit (apo B-100) and a unique apolipoprotein apo(a) attached to apoB-100 by a disulphide bridge (1-4). A schematic structure of lipoprotein(a) is presented in Figure 1 . The apo(a) structure resembles plasminogen, the zymogen of plasmin, a proteolytic enzyme of the fibrinolytic system (3-5). Plasminogen consists of a trypsine-like protease domain and five pretzel or ring-like structures, called kringles. Lipoprotein(a) lacks kringle 1 to 3 , but contains a kringle-4 region, which is repeated anywhere between 13 and 37 times, one copy of the kringle-5 domain and a serine protease domain, which is more that 908 homologous to that of plasminogen (3). However, the lipoprotein(a) protease is inactive as a result of an aminoacid substitution in the active site (3). Because of the similarity with plasminogen, lipoprotein(a) is supposed to compete for some physiological functions, like binding to fibrin(ogen) and tissue-plasminogen activator (4-8). The number of kringle 4 repeats in apo(a) is highly variable and genetically determined, generating broad inter-individual molecular weight differences (9-12). The size of apo(a) isoproteins is inversely correlated to the serum lipoprotein(a) concentration. Epidemiological studies have demonstrated that the risk of coronary heart disease is associated with high serum lipoprotein(a) concentrations, independent of other lipoprotein parameters $(3,5,13-18)$. Physical exercise has a potentially lipid and lipoprotein lowering effect and therefore may protect against ischemic heart disease $(19,20)$. Although the intra-individual concentration of Iipoprotein(a) is claimed to be very stable throughout life with only a minimal influence of life-style factors, only 
few -cross-sectional- data exist on the influence of exercise on $\mathrm{Lp}(\mathrm{a})$ levels $(3,11,21,22)$. Our study was designed to investigate prospectively the long-term overall effect of physical exercise on Lp(a) levels in sera of previously sedentary males and females.

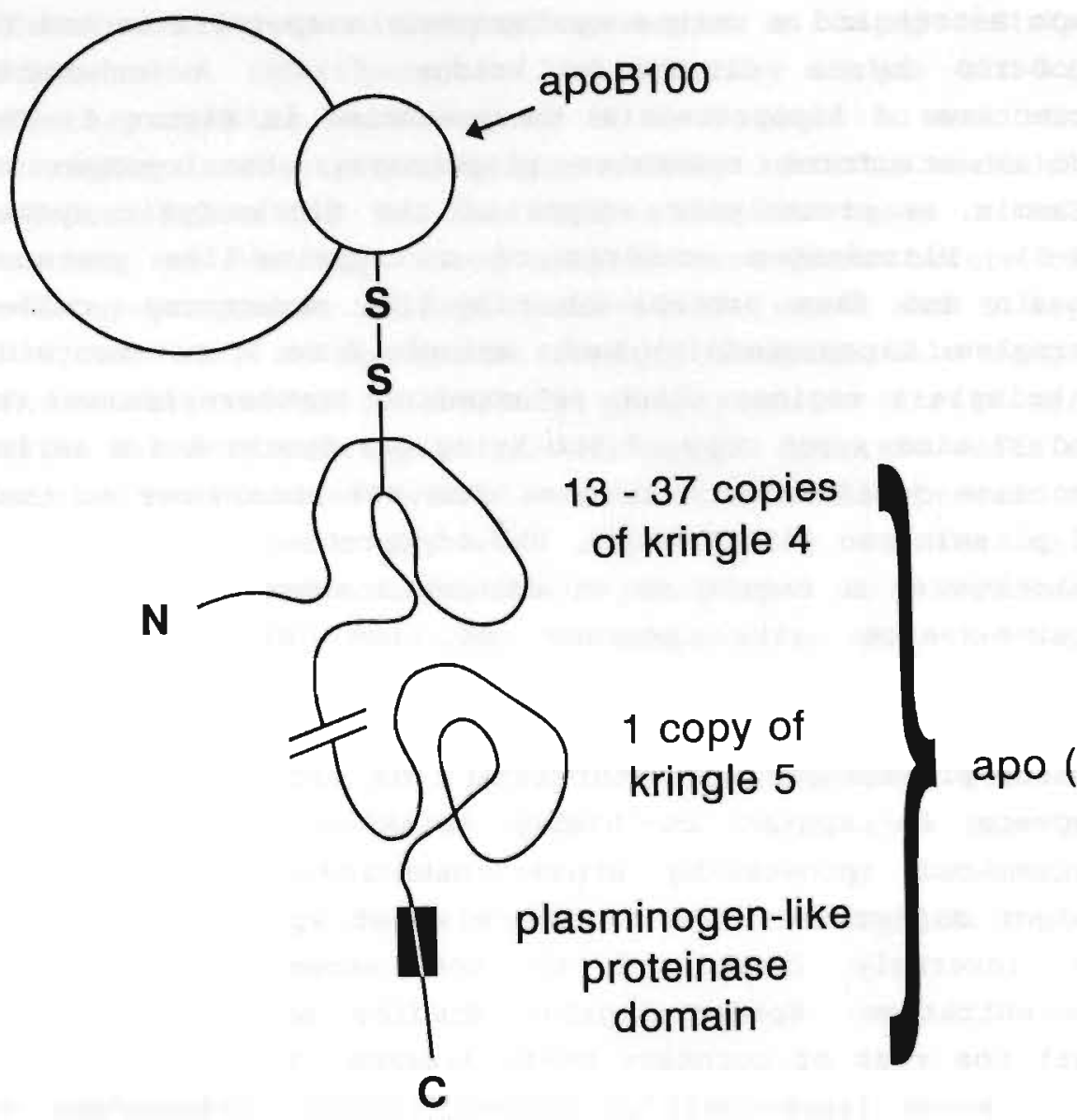

Figure 1

Schematic representation of lipoprotein(a) structure. 


\section{MATERIAL AND METHODS}

\section{subjects}

Forty-seven participants were selected from 370 people who replied to advertisements in two local newspapers and on a local radio station. Those who participated in any sports such as running or jogging or who were active for more than 1 hour per week in other recreational sports were excluded. After two information sessions all subjects gave their written informed consent. Thirty-four of the 47 participants fulfilled the study, 20 males aged from 32-49 years (median:39) and 14 females aged from 27-41 years (median:35). Some of the reasons for drop-out were mental stress $(n=2)$, injuries $(n=4)$, moving away due to change in working place $(n=2)$ and relational problems $(n=2)$. All individuals kept their diet and other living habits like the use of alcohol as constant as possible during the study. Among the participants were three female and six male cigarette smokers (maximum 10 cigarettes a day), who continued to smoke during the test period.

The median (interquartile range) body weight shifted in the male population from $74.6(69-79.8) \mathrm{kg}$ at start to 72.2 $(64.8-77.7) \mathrm{kg} \quad(p<0.01)$ at the end of the training programme. In the female population from 63.0 (57.0-65.8) $\mathrm{kg}$ to $60.7(55.0-63.4) \mathrm{kg}(\mathrm{n.s.})$. The median (interquartile range) body mass index shifted in the male group from 23.1 $(21.6-25.5) \mathrm{kg} / \mathrm{m}^{2}$ to $22.0(21.1-24.4) \mathrm{kg} / \mathrm{m}^{2} \quad(\mathrm{p}<0.01)$ and in the female group from $21.6(21.3-22.6) \mathrm{kg} / \mathrm{m}^{2}$ to $21.5 \quad(21.3-$ $22.3) \mathrm{kg} / \mathrm{m}^{2}$ (n.s.).

Aerobic power on a bicycle ergometer was used to measure the effect of the increase in cardiovascular fitness during the training programme. The median aerobic power increased in males from 226 watt at the start to 252 watt at the end of the programme $(p<0.01)$. In females from 160 watt to 189 watt $(p<0.05)$. 


\section{Training programme}

After a medical examination and pre-exercise control measurements all volunteers participated in a 9 month endurance training programme preparing for a half marathon run $(21 \mathrm{~km})$. The schedule was essentially the same as previously described by Janssen et al (23). The training period lasted 9 months. After 24 and 36 weeks of training all subjects ran a $15 \mathrm{~km}$ and $21 \mathrm{~km}$ race, respectively. During the general preparation period the volunteers trained 3-4 times a week; 6 weeks before each contest the number of the training sessions was enhanced to 5-6 times a week. Beside the attention paid to style and technique of running, stretching, speed, intervals, warming-up and cooling-down, the training included three elements: longdistance running, running at high speed and interval training.

\section{Blood samples}

Blood samples were drawn between 8.00 and 9.00 am. All subjects were seated before phlebotomy and had not eaten or exercised during the preceding ten hours. Samples were taken before the start of the training programme and, in order to avoid acute effects, five days before both races as well as five days after the half marathon run. Within one hour from sample collection serum was separated from blood, snap-frozen in aliquots, stored at $-70^{\circ} \mathrm{C}$ in plastic tubes and thawed at $37^{\circ} \mathrm{C}$ immediately prior to serial analysis.

\section{Methods}

Lipoprotein(a) was measured using a commercially available enzyme-linked immunosorbent assay (ELISA) kit (TintElize lipoprotein(a) kit, Biopool AB, Umea, Sweden) (24). This assay includes ready to use micro-test plates containing affinity purified sheep anti-apo(a) Ig and sheep antiapo(a) peroxidase conjugated Ig. The intra-assay 
coefficient of variation was $3.1 \%$ at a concentration of 150 $\mathrm{mg} / \mathrm{I} \mathrm{Lp}(\mathrm{a})$ and 4,88 at a concentration of $65 \mathrm{mg} / \mathrm{I} \mathrm{Lp}(\mathrm{a})$.

\section{statistics}

All statistics were calculated with SPSS/PC+ Statistics 4.0 statistical data analysis (SPSS InC., Chicago USA). wilcoxon signed rank test was used to compare differences in pre-, during and post-exercise samples. The Mann-Whitney wilcoxon test was used to compare the male and female population. All data are given as medians and interquartile ranges ( $i . e$. the $25^{\text {th }}$ to $75^{\text {th }}$ percentile ranges).

\section{RESULTS}

All individual lipoprotein(a) values are shown in Table I. Median (interquartile range) serum lipoprotein(a) in the male and female group after log transformation is shown in Figure 2. Median (interquartile range) pre-training values in the male group were $32(11-63) \mathrm{mg} / \mathrm{l}$ and in the female group 65 (25-199) $\mathrm{mg} / 1$. After 24 weeks of training serum lipoprotein(a) concentrations in both groups were significantly increased; in the male group median (interquartile range) lipoprotein(a) level was 37 (15-63) $\mathrm{mg} / \mathrm{l}(\mathrm{p}<0.05)$ and in the female group $67(22-357) \mathrm{mg} / \mathrm{l}$ $(\mathrm{p}<0.01)$. After 36 weeks, five days before the half marathon competition median (interquartile range) lipoprotein(a) levels were in the male group 69 (39-132) $\mathrm{mg} / \mathrm{l}$ and in the female group $108(56-450) \mathrm{mg} / \mathrm{l}$. These increases were significant in comparison to pre-training values $(p<0.01)$ as well as to lipoprotein(a) concentrations after 24 weeks of training $(p<0.01)$. These increases were still significant $(p<0.01)$ in both male and female group after log transformation of the data. Five days after the half marathon run, median (interquartile range) serum lipoprotein(a) levels were in the male group 58 (35-143) $\mathrm{mg} / \mathrm{l}$ and in the female group $170(57-397) \mathrm{mg} / \mathrm{l}$. 
TABLE 1: lipoprotein(a) levels in men $(n=20)$ and women $(n=14)$ before (1), during $(2,3)$, and after (4) the trainingprogramme.

\section{lipoprotein(a) concentrations (mg/l)}

1

234

\begin{tabular}{|c|c|c|c|c|c|}
\hline \multirow[t]{7}{*}{ women } & 1 & 26 & 43 & 86 & 81 \\
\hline & 2 & 46 & 39 & 56 & 106 \\
\hline & 3 & 218 & 357 & 599 & 570 \\
\hline & 4 & 37 & 67 & 108 & 126 \\
\hline & 5 & 15 & 15 & 61 & 37 \\
\hline & 6 & 10 & 10 & 7 & 61 \\
\hline & 7 & 193 & 381 & 450 & 339 \\
\hline . & 8 & 84 & 129 & 125 & 213 \\
\hline & 9 & 40 & 24 & 56 & nI \\
\hline & 10 & 24 & 22 & 61 & 44 \\
\hline & 11 & 104 & 191 & 270 & 256 \\
\hline & 12 & 310 & 412 & 778 & 682 \\
\hline & 13 & 388 & 432 & 750 & 787 \\
\hline & 14 & 133 & 195 & 327 & 323 \\
\hline \multirow[t]{20}{*}{ men } & 1 & 14 & 15 & 63 & 43 \\
\hline & 2 & 78 & 80 & 137 & 151 \\
\hline & 3 & 32 & 12 & 45 & 52 \\
\hline & 4 & 10 & 10 & 1 & 6 \\
\hline & 5 & 5 & 10 & 24 & 37 \\
\hline & 6 & 11 & 18 & 40 & 21 \\
\hline & 7 & 38 & 37 & 63 & 51 \\
\hline & 8 & 1 & 23 & 30 & 32 \\
\hline & 9 & 64 & $\mathrm{nr}$ & 116 & 118 \\
\hline & 10 & 102 & 122 & 249 & 195 \\
\hline & 11 & 11 & 16 & 35 & 29 \\
\hline & 12 & 21 & 45 & 59 & 58 \\
\hline & 13 & nr & 45 & 130 & 123 \\
\hline & 14 & 40 & 58 & 76 & 82 \\
\hline & 15 & 386 & 407 & 659 & 673 \\
\hline & 16 & 61 & 67 & 202 & 180 \\
\hline & 17 & 42 & 50 & 107 & 134 \\
\hline & 18 & 130 & 400 & 519 & 528 \\
\hline & 19 & 32 & 58 & 71 & 118 \\
\hline & 20 & 1 & 5 & 6 & 30 \\
\hline
\end{tabular}

$\mathrm{nr}=$ no result 


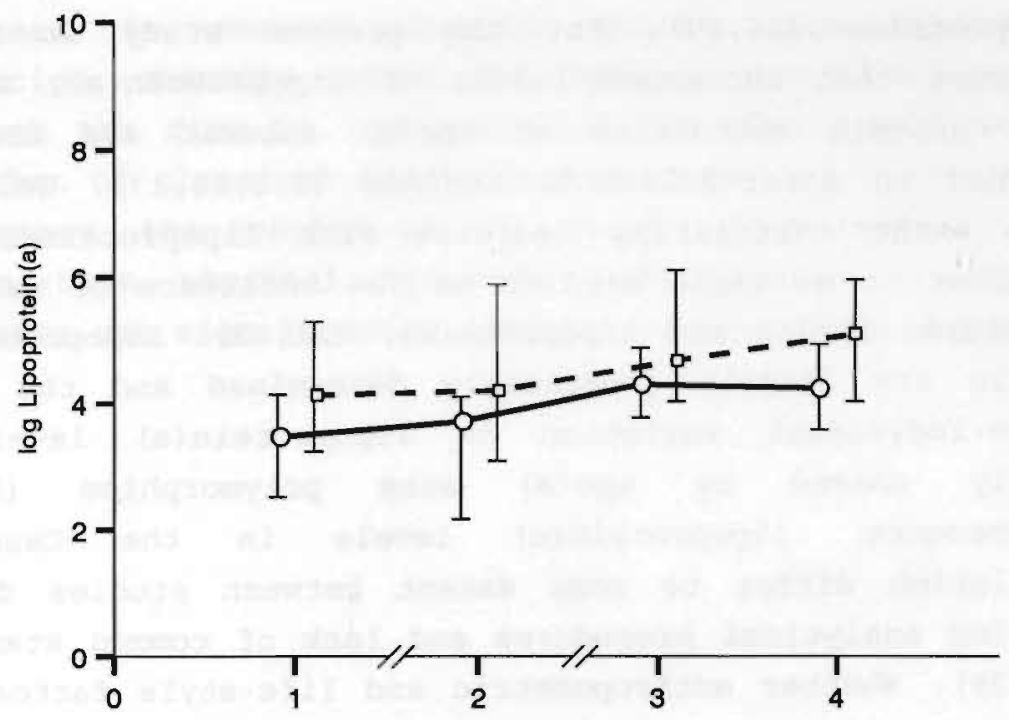

Figure 2

Median (interquartile range) log lipoprotein(a) levels in serum of males (0) and females ( $\square$ ) before the training programme (1), 5 days before the $15 \mathrm{~km}$ race (2) and 5 days before (3) and after (4) the half marathon run. Median (interquartile range) log lipoprotein(a) values in the male group were respectively (1) $3.5(2.5-4.1)$, (2) $3.7 \quad(2.7-$ $4.1)$, (3) $4.3(3.8-4.9),(4) 4.2(3.6-4.9)$ and in the female group (1) $4.1(3.2-5.3)$, (2) $4.2(3.1-5.9)$, (3) 4.7 $(4.0-6.1)$, (4) $5.1(4.0-6.0)$.

\section{DISCUSSION}

Physical exercise, performed at proper intensity, duration and frequence has been reported to provoke a beneficial effect on trained and untrained individuals towards a reduced risk for cardiovascular disease. Several epidemiological studies revealed a positive correlation between physical fitness and a reduced risk for cardiovascular disease $(19,25)$. This potentially positive effect is - at least partially - mediated through the influence of endurance training on serum lipids and 
lipoproteins $(26,27)$. For the present study it is of interest that increased levels of lipoprotein(a), a LDLlike protein containing an apo(a) subunit are strongly related to atherosclerotic lesions $(3,8,15,17)$. Only few data exist correlating exercise with lipoprotein(a), in contrast to multiple studies on the influence of exercise on plasma lipids and lipoproteins, $(21,22)$. Lipoprotein(a) levels are largely genetically determined and the broad inter-individual variation in lipoprotein(a) levels is mainly caused by apo(a) size polymorphism $(9,12)$. Furthermore, lipoprotein(a) levels in the caucasian population differ to some extent between studies due to varying analytical procedures and lack of common standards $(28,29)$. Whether anthropometric and life-style factors can influence lipoprotein(a) levels is not clear $(3,11,18)$. In the present study, investigating the influence of exercise on lipoprotein(a) levels, in both the male and female group serum lipoprotein(a) levels were increased almost two-fold after 36 weeks of training, five days before the half marathon run in comparison to pre-training levels and to serum levels after 24 weeks of training. This finding is in contrast with other studies showing an exercise induced decrease in lipoprotein(a) levels or no change $(21,22)$. However, in our study the training schedule was substantially more intensified in preparation for the $21 \mathrm{~km}$ race. This probably caused chronic physical stress, leading to increased levels of acute phase reactants, like fibrinogen, as we reported previously (30). Several studies have shown a strong correlation between fibrinogen and lipoprotein(a) concentrations, although a reason for this association is not known $(2,31)$. One can speculate whether lipoprotein(a) has the characteristics of an acute phase reactant, and concentrates at places of tissue damage and woundhealing, in order to stabilize the fibrin network and to support membrane synthesis during cell renewal $(5,32,33)$. Serum lipoprotein(a) concentrations are 
increased in several disease states like myocardial infarction, unstable angina and impaired glucose tolerance, although the rise in lipoprotein(a) is mostly much weaker than that of classical acute phase proteins $(16,17,34,35)$.

In summary, the results of the present study indicate that a long-term physical exercise programme of increasing intensity can significantly enhance lipoprotein(a) levels. 


\section{REFERENCES}

1. Berg $K$. A new serum type in man-the Lp system. Acta Path 1963; 59: 369-82.

2. Heinrich J, Sandkamp M, Kokott R, Schulte H, Assmann G. Relationship of Lipoprotein(a) to variables of coagulation and fibrinolysis in a healthy population. Clin Chem 1991; 37: 1950-4.

3. Jenner JL, Ordovas JM, Lamon-Fava S, Schaefer MM, Wilson PWF. Effects of age, sex, and menopausal status on plasma lipoprotein(a) levels; the Framingham offspring study. Circulation 1993; 87 : 1135-41.

4. Edelberg J, Pizzo SV. Why is lipoprotein(a) relevant to thrombosis? Am J Clin Nutr 1992; 56: 791S-2S.

5. Oshima $S$, Uchida $K$, Yasu $T$, Uno $K$, Nonogi $H$, Haze $K$. Transient increase of plasma lipoprotein(a) in patients with unstable angina pectoris; does lipoprotein(a) alter fibrinolysis? Arterioscler Tromb 1991; 11: 17727 .

6. Loscalzo J, Weinfeld M. Fless GM, Scanu AM. Lipoprotein (a), fibrin binding, and plasminogen activation. Arteriosclerosis 1990; 10: 240-5.

7. Glueck CJ, Glueck HI, Tracy $T$, speirs J, McCray C, Stroop D. Relationships between lipoprotein(a), lipids, apoliproteins, basal and stimulated fibrinolytic regulators, and d-dimer. Metabolism 1993; 42: 236-46.

8. Szczeklik A, Radwan J, Kubicka A, Libura M, Sacha $T$ et al. Plasma fibrinolytic activity in healthy subjects with high and low lipoprotein(a) concentrations. Thromb Res 1992; 66: 391-5.

9. Utermann G, Menzel HJ, Kraft HG, Duba HC, Kemmier HG, Seitz C. Lp(a) glycoprotein phenotypes. Inheritance and relation to $\mathrm{Lp}(\mathrm{a})-\mathrm{lipoprotein}$ concentrations in plasma. $\mathrm{J}$ Clin Invest $1987 ; 458-65$.

10. Cobbaert $C$ and Kesteloot H. Serum lipoprotein(a) levels in racially different populations. Am J Epidemiol 1992; 136: 441-9.

11. Slunga $L$, Asplund $K$, Johnson $O$ and Dahlén $G H$. Lipoprotein(a) in a randomly selected 25-64 year old population: the northern sweden monica study. J Clin Epidemiol 1993; 46: 617-34.

12. Austin MA, Sandholzer C, Selby JV, Newman B, Krauss RM, Utermann G. Lipoprotein(a) in women twins: heritability and relationship to apolipoprotein(a) phenotypes. Am J Hum Genet 1992; 51 : 829-40.

13. Rhoads GG, Dahlen $G$, Berg $K$, Morton NE, Dannenberg $A L$. $\mathrm{Lp}(\mathrm{a})$ lipoprotein as a risk factor for myocardial infarction. JAMA, 1986; 256: 2540-4.

14. Rosengren A, Wilhelmsen L, Eriksson E, Risberg B, wedel H. Lipoprotein(a) and coronary heart disease: a prospective case-control study in a general population sample of middle aged men. Br Med J 1990; 301: 1248-51.

15. Tennant M, McGeachie JK. Lipoprotein(a) and its role in 
occlusive vascular disease. Ann R Coll Surg Engl 1993; 75: 3-7.

16. Graziani MS, Zanolla L, Righetti G, Nicoli M, Modena N et al. Lipoprotein(a) concentrations are increased in patients with myocardial infraction and angiographically normal coronary arteries. Eur $\mathrm{J} \mathrm{Clin}$ Chem Clin Biochem 1993; 31: 135-7.

17. Vella J-C, Jover $\mathrm{E}$. Relation of lipoprotein(a) in 11to 19-year-old adolescents to parental cardiovascular heart disease. Clin Chem 1993; 39: 477-80.

18. Abe A, Noma A, Lee YJ, Yamaguchi $H$. Studies on apolipoprotein(a) phenotypes. Part 2. Phenotype frequencies and $\mathrm{Lp}(\mathrm{a})$ concentrations in different phenotypes in patients with angiographically defined coronary artery diseases. Atherosclerosis 1992; 96: 915.

19. Ekelund L-G, Haskell WL, Johnson JL, Whaley FS, Criqui MN, Sheps DS. Physical fitness as a predictor of cardiovascular mortality in asymptomatic North American men. N Engl J Med 1991; 319: 1379-84.

20. Aellen $R$, Hollmann $W$, Boutellier U. Effects of aerobic and anaerobic training on plasma lipoproteins. Int $\mathrm{J}$ Sport Med 1993; 14: 396-400.

21. Austin A, Warty $V$, Janosky J, Arslanian $S$. The relationship of physical fitness to lipid and lipoprotein(a) levels in adolescents with IDDM. Diabetes Care 1993; 16: 421-5.

22. Lobo RA, Notelovitz M, Bernstein $L$, Khan FY, Ross RK, Paul WL. Lp(a) lipoprotein: relationship to cardiovascular disease risk factors, exercise, and estrogen. Am J Obstet Gynecol 1992; 166: 1182-90.

23. Janssen GME. Marathon running: functional changes in male and female subjects during training and contests. Int $J$ Sports Med 1989; 10 (suppl 3): 117-90.

24. Brändstorm $A$, Johnson $O$, Dahlen $G$, Ranby $M$. Lp(a) levels in a healthy population measured by a new enzyme linked immuno sorbent assay (abstract). Thromb Haemost $1989 ; 62: 573$.

25. Sandvik L, Erikssen J, Thaulow E, Erikssen G, Mundal R, Rodahl K. Physical fitness as a predictor of mortality among healthy, middle-aged Norwegian men. $N$ Engl $\mathrm{J}$ Med $1993 ; 328: 533-7$.

26. Rhoads GG, Gulbrandsen CL, Kagan A. Serum lipoproteins and coronary heart disease in a population study of Hawaii Japanese men. N Engl J Med 1976; 294: 293-8.

27. Criqui MH, Heiss MPHG, Cohn R, Cowan LD, Suchindran CM, Bangdiwala $S$ et al. Plasma triglyceride level and mortality from coronary heart disease. $N$ Engl $J$ Med 1993; 328: $1220-5$.

28. Craig WY, Ledue TB. Lipoprotein(a) and the acute phase response. Clin Chim Acta 1992; 210: 231-2.

29. Kostner GM. Standardization of Lp(a) assays. Clin Chim Acta 1992; 191-4. 
30. Ponjee GAE, Janssen GME, van wersch JWJ. Prolonged endurance exercise and blood coagulation: a 9 month prospective study. Bl Coag Fibrinol 1993; 4: 21-5.

31. Halvorsen $S$, Skjønsberg OH, Berg $k$, Ruyter $R$, Godal HC. Does $L p(a)$ lipoprotein inhibit the fibrinolytic system? Thromb Res 1992; 68: 223-32.

32. Brown MS, Goldstein JL. Plasma lipoproteins. Teaching old dogmas new tricks. Nature 1987; 330: 113-4.

33. Maeda $S$, Abe A, Seishma $M$, Makino $K$, Noma $A$, Kavade $M$. Transient changes of serum lipoprotein(a) as an acute phase protein. Atherosclerosis 1989; 78: 145-50.

34. Couper JJ, Bates DJ, Cocciolone R, Magarey AM, Boulton TJC, Penfold JL, Ryall RG. Association of lipoprotein(a) with puberty in IDDM. Diabetes Care 1993; 16: 869-73.

35. Slunga $L$, Johnson $O$, Dahlén $G H$, Eriksson $S$. Lipoprotein(a) and acute phase proteins in acute myocardial infarction. Scand $J$ Clin Lab Invest 1992; 52: 95-101. 


\section{CHAPTER 5}

PROLONGED ENDURANCE EXERCISE AND BLOOD COAGULATION:

A 9 MONTH PROSPECTIVE STUDY

G.A.E. Ponjee, G.M.E. Janssen, and J.W.J. van Wersch

Also published in:

Blood Coagulation and Fibrinolysis 1993; 4: 21-5.

(Reproduced with permission) 


\section{SUMMARY}

To study the long-term overall effect of physical exercise on blood coagulation, 20 sedentary males and 14 sedentary females were trained 3 to 4 times a week with increasing intensity during 9 months. After 24 and 36 weeks all subjects ran a $15 \mathrm{~km}$ and a half marathon $(21 \mathrm{~km})$ race, respectively. Blood samples were drawn before the training programme, five days before both races and five days after the half marathon run. Plasma factor VIII coagulant activity and von willebrand factor antigen concentration did not increase during the training programme. In both males and females plasma fibrinogen concentration was not enhanced after 24 weeks of training, but increased preparing for the $21 \mathrm{~km}$ race and was still raised significantly $(p<0.01)$ five days later. In both groups no significant changes in plasma thrombin-antithrombin III concentrations were observed during the training programme.

The results of this study demonstrate that an exercise programme of increasing intensity induces physical stress which has significant effects on plasma fibrinogen concentration, even at rest. But, in contrast to acute post exercise effects, a regular physical fitness programme does not induce a long-term activation of the haemostatic system. 


\section{INTRODUCTION}

In response to the growing evidence that regular physical activity produces significant benefits, both physically and mentally, more and more people in all age groups start to work out on a regular basis. Although there is a general consensus that exercise prevents cardiovascular disease $(1,2)$, many studies have shown that exercise acutely disturbs the haemostatic system causing an increase in the coagulability of the blood (3-13). Especially increases in factor VIII coagulant activity (factor VIII:c) and von Willebrand factor concentration due to acute bouts of exercise are well described (4-11; Figure 1). However the magnitude of the changes in blood coagulation varies considerably in the reported literature (5-16). This may be due to a lack of uniformity, quantitation of the intensity and the duration and type of exercise utilized. It is important to distinguish between physiological events that occur with acute bouts of exercise and those changes, which accompany physical conditioning. While most reports describe acute post-exercise effects, little is known of the adaptive response on blood coagulation by the body due to chronic prolonged exercise. This study was designed to investigate the long-term overall effect of physical exercise on blood coagulation.

\section{MATERIAL AND METHODS}

\section{Subjects}

Forty-seven participants were selected from 370 people who replied to advertisements in two local newspapers and on a local radio station. Those who participated in any sports such as running or jogging or who were active for more than 1 hour per week in other recreational sports were excluded. After two information sessions all subjects gave their written informed consent. Thirty-four of the 47 


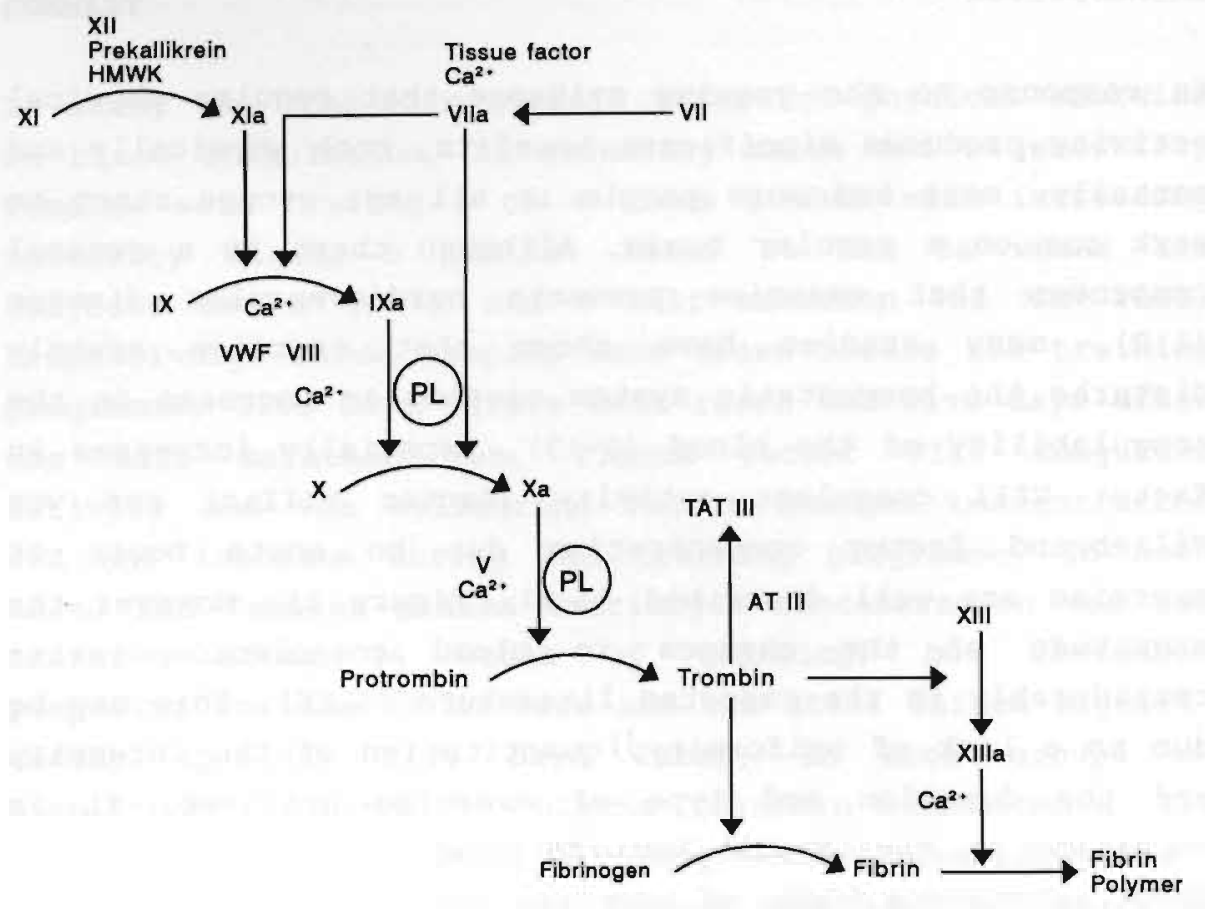

\section{Figure 1}

The blood coagulation cascade.

HMWK = High Molecular Weight Kininogen; VWF = von Willebrand Factor; $\mathrm{PL}$ = platelets; TATIII = thrombinantithrombin III.

participants fulfilled the study, 20 males aged from 32-49 years (median:39) and 14 females aged from 27-41 years (median:35). Some of the reasons for drop-out were mental stress $(n=2)$, injuries $(n=4)$, moving away due to change in working place $(n=2)$ and relational problems $(n=2)$. Among the participants were three female and six male cigarette smokers (maximum 10 cigarettes a day), who continued to smoke during the test period. The median body weight shifted in males from $74.6 \mathrm{~kg}$ at start to $72.2 \mathrm{~kg}(p<0.01)$ 
after the half marathon. In females from $63.0 \mathrm{~kg}$ to $60.7 \mathrm{~kg}$ (n.s.). As measurable effect of the increase in cardiovascular fitness in the course of the training programme, the aerobic power on a bicycle ergometer was used. The median aerobic power increased in males from 226 Watt at the start to 252 watt at the end of the programme $(p<0.01)$. In females from 160 watt to 189 watt $(p<0.05)$.

\section{Training programme}

After a medical examination and pre-exercise control measurements, all volunteers participated in a 9 month endurance training programme, preparing for a half marathon run $(21 \mathrm{~km})$. The schedule was essentially the same as previously described by Janssen et al (17). The training period lasted 9 months. After 24 and 36 weeks of training all subjects ran a $15 \mathrm{~km}$ and $21 \mathrm{~km}$ race, respectively. During the general preparation period, the volunteers trained 3-4 times a week; 6 weeks before each contest the training programme was intensified to 5-6 times a week. Beside the attention paid to style and technique of running, stretching, speed, intervals, warming-up and cooling-down, the training included three elements: longdistance running, running at high speed and interval training. The elements followed each other naturally as far as the intensity is concerned. The intensity percentage of maximal heart rate was for long-distance runs 70-80\%, for running at a fixed pace 80-95\% lover 200-2000 $\mathrm{m}$ depending on the training status) and for intervals over shorter distances $(200-400 \mathrm{~m})$ 95-100\%. By putting these three elements together (in relation of 70:20:10\% of the distances per week) a gradual undulating increase of the amount of training can be accomplished, by training to a maximum of $60 \mathrm{~min}$ per training session in the first part of the study, and to a maximum of 100 min per training session in the second part. 


\section{Blood samples}

Blood samples were drawn between 8.00 and 9.00 am, before the start of the training programme, $f$ ive days before both races as well as five days after the half marathon run. Non-traumatic venipuncture was performed and nine volumes of freshly drawn blood were mixed with one volume trisodium citrate $(0.11 \mathrm{~mol} / 1)$. After centrifugation for $30 \mathrm{~min}(3000$ g) at $4^{\circ} \mathrm{C}$, the plasma was stored in aliquots at $-70^{\circ} \mathrm{C}$ in plastic tubes and thawed at $37^{\circ} \mathrm{C}$ immediately prior to serial analysis.

\section{Methods}

Fibrinogen was determined by the clotting assay of clauss. Reference values, determined in plasma from 50 healthy volunteers ranged from 2.0 to $4.0 \mathrm{~g} / 1$. The fibrinogen analysis showed an intra-assay coefficient of variation of 3.28 and an inter-assay coefficient of variation of $4.1 \%$. The von willebrand factor concentration was quantitated with an Elisa test kit of Boehringer Mannheim Corp. (Mannheim, Germany). For the factor VIII:c determination an activated partial thromboplastin time (APTT) one stage clotting assay was performed, using a factor deficient plasma from Behring (Marburg, G). The coefficients of variation, obtained for von willebrand factor, were $3.4 \%$ for the intra-assay variation and $6.7 \%$ for the inter-assay variation, for the factor VIII:c determinations, coefficients of variation of $3.7 \%$ and $6.1 \%$ were found. Thrombin-antithrombin III was determined with an ELISA kit of Behring cooperation (Marburg, FRG). Reference values, determined in plasma of 50 healthy volunteers were 1.0 $4.1 \mu \mathrm{g} / 1$. For thrombin-antithrombin III the intra-assay and inter-assay coefficients of variation were $5.1 \%$ and $7.4 \%$, respectively. 


\section{Statistics}

All statistics were calculated with SPSS/PC+ Statistics 4.0 statistical data analysis (SPSS Inc., Chicago USA). wilcoxon signed rank test was used to compare differences in pre-, during and post-exercise plasma samples. The MannWhitney wilcoxon test was used to compare the male and female population. All data are given as medians and interquartile ranges.

\section{RESULTS}

Median (interquartile range) plasma factor VIII:c, von willebrand factor, fibrinogen and thrombin-antithrombin III concentrations, are summarised in Figures 2-5. Median factor VIII:c concentrations in the male and female population did not change significantly during the training programme, nor did the median values of the von willebrand factor concentration.

In both the male and female population, fibrinogen concentrations remained within the reference range during the training programme. But in the male population,. fibrinogen concentrations were significantly increased (p<0.01) 5 days before the half marathon competition and were still elevated significantly $(p<0.01) \quad 5$ days afterwards, in comparison with pre-training levels. In the female group, fibrinogen concentrations 5 days after the half marathon run were significantly raised $(p<0.01$ ) compared with pre-training levels.

Median pre-training thrombin-antithrombin III concentrations were within the reference range for both groups, although in 6 males and 1 female, thrombinantithrombin III levels were increased before the training programme. Neither in the male nor in the female population, median plasma thrombin-antithrombin III levels changed significantly during the test period. 


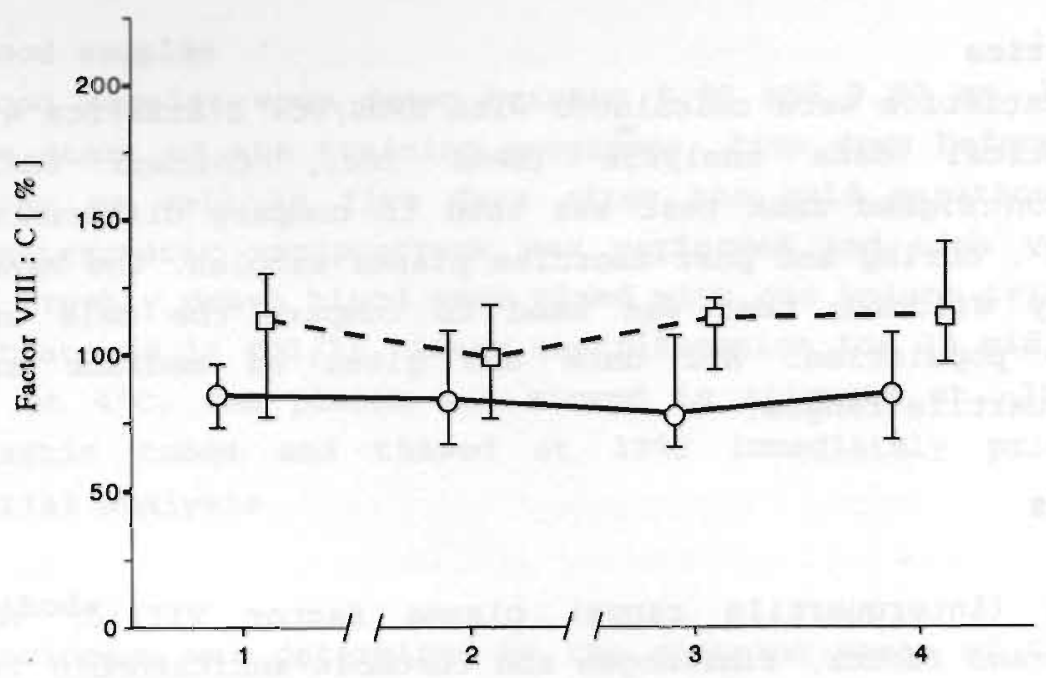

Figure 2

Median (interquartile range) factor VIII:c activity ( 8 ) in plasma of 20 males (O) and 14 females (ㅁ) before the training programme (1), 5 days before the $15 \mathrm{~km}$ race (2) and 5 days before (3) and after (4) the half marathon run.

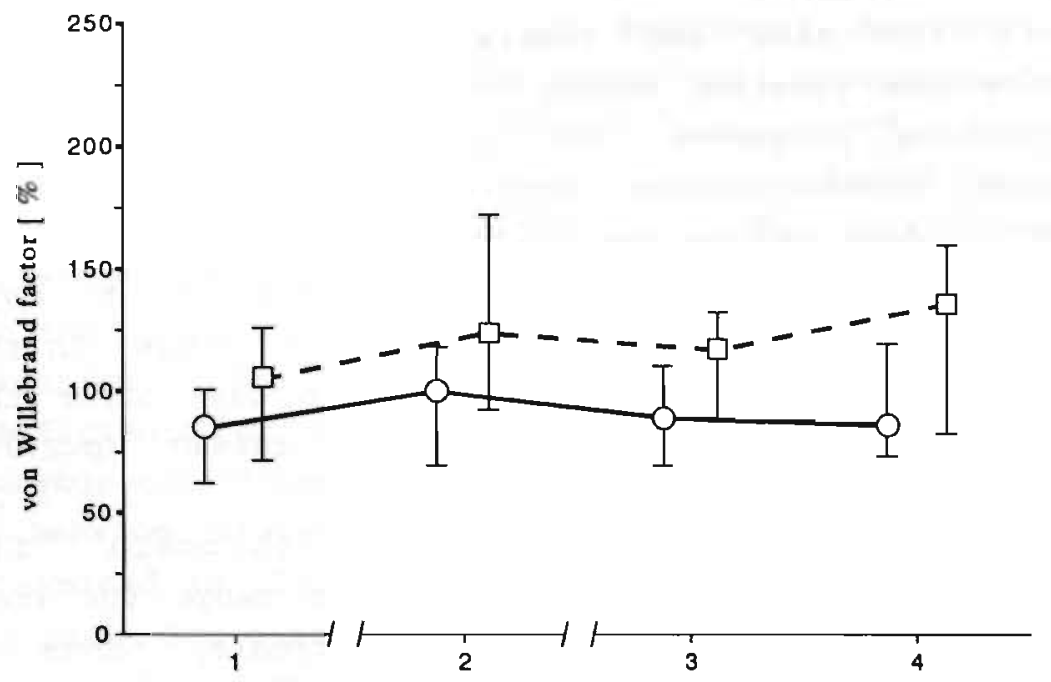

Figure 3

Median (interquartile range) von willebrand factor antigen concentration ( 8 ) in plasma of 20 males (0) and 14 females (a) before the training programme (1), 5 days before the 15 $\mathrm{km}$ race (2), and 5 days before (3) and after (4) the half marathon run. 


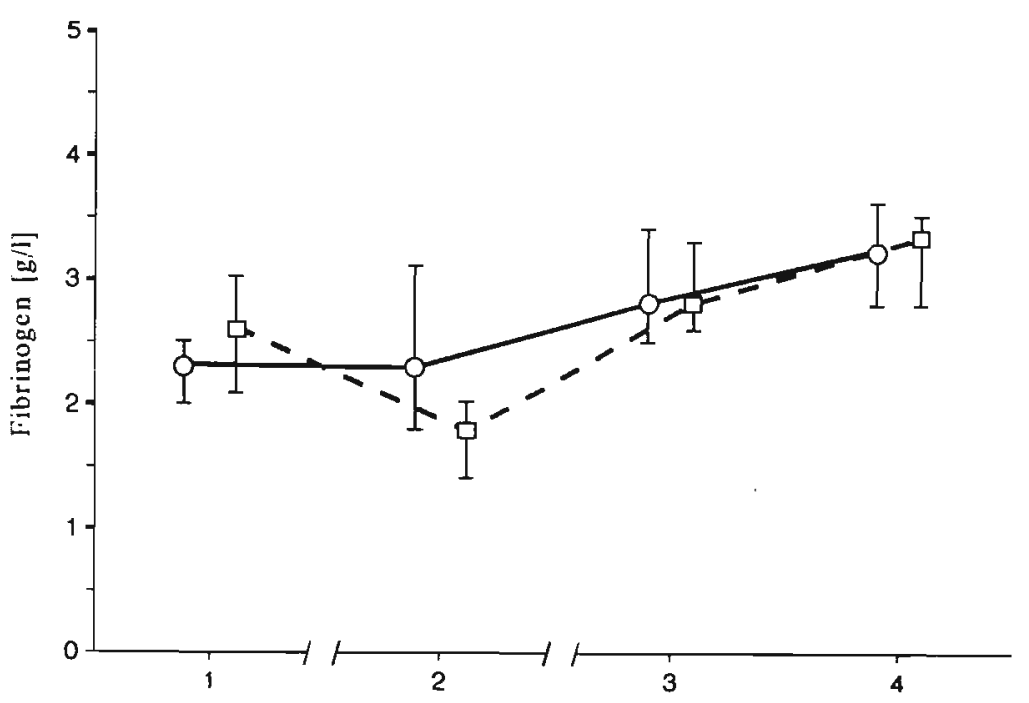

Figure 4

Median (interquartile range) fibrinogen concentration ( $/$ / I) in plasma of 20 males (O) and 14 females ( 0 ), before the training programme (1), 5 days before the $15 \mathrm{~km}$ race (2) and 5 days before (3) and after (4) the half marathon run.

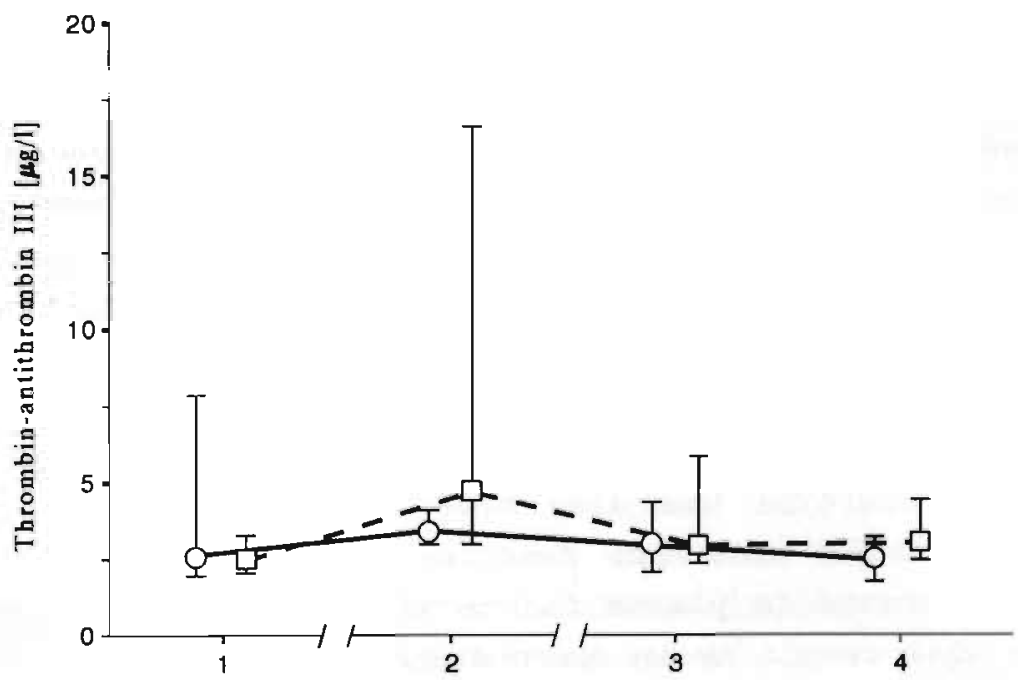

Figure 5

Median (interquartile range) thrombin-antithrombin III (TAT III) concentration $(\mu \mathrm{g} / \mathrm{I})$ in plasma of 20 males (0) and 14 females (), before the training programme (1), 5 days before the $15 \mathrm{~km}$ race (2) and 5 days before (3) and after (4) the half marathon run. 


\section{DISCUSSION}

Physical exercise, performed at proper intensity, duration and frequency, will induce significant improvements in physical working capacity of sedentary individuals at all ages. A single bout of physical effort or repeated exercise, may change the hemodynamics of blood and influence the haemostatic system. Most of the data concerning the effects of exercise on blood coagulation, are limited to acute post-exercise studies, based on one maximal or submaximal workload. A universal finding is a significant enhancement acutely after exercise of factor VIII:c activity and of plasma von willebrand factor concentration (4-10). These rises are most likely due to an increased release of these substances $(6,7)$. Some authors report a disproportional increase in factor VIII:c over von willebrand factor, as a result of in vivo activation by thrombin, which may represent a hypercoagulable state $(5,11)$, while others do not observe such a modification of factor VIII clotting activity by thrombin (12). The observed increases in factor VIII:c are reported to be at peak value, 5-10 min after exercise and coincide with peak blood lactate concentrations (9). After $20 \mathrm{~min}$ to $60 \mathrm{~min}$ post-exercise, factor VIII:c concentrations are still increased $(13,14)$ and sometimes 24 hours later an increase in both factor VIII:c and von willebrand factor can still be observed (15), although a return to baseline levels 30 min after exercise has also been reported (16). In our study, prolonged endurance exercise did not induce a long lasting increase in plasma factor VIII:c or von willebrand factor. This result is in concordance with the finding that factor VIII:C and von willebrand factor concentrations, in plasma of endurance trained athletes at rest, do not differ from controls (12). The fibrinogen concentration between the male and female population before and after the start of the exercise programme did not differ significantly. The 
fibrinogen content in the training period remained in the reference range and the values were comparable with those observed in runners at rest and in control groups (12). But, after 9 months of training, a significant rise in plasma fibrinogen concentration was observed in comparison with control levels and with those after 24 weeks of training in both groups. Increases in fibrinogen concentration have been observed acutely after exercise and 24 hours later $(7,15,16)$ as well as in reaction to mental stress and adrenaline infusion (7). Fibrinogen as an acute phase reactant, responds to acute and chronic stress (7) and is increased in different disease states, like diabetes type II (18) and coronary artery disease $(19,20)$. The fibrinogen increase at the end of the training programme, can be explained by the fact that the exercise schedule was substantially intensified, in preparation for the half marathon run. This most likely caused a chronic stress on the body, which was responsible for the elevated fibrinogen concentration. Other investigators found a decrease or no change in fibrinogen concentrations during an exercise programme, and these results are comparable with ours after 13 weeks of training $(12,21)$. Median pre-training plasma thrombin-antithrombin III levels did not differ significantly between the male and female population and were comparable with those found by others $(22,23)$, although some male individuals had unexplainable high thrombin-antithrombin III levels. Thrombin-antithrombin III is a sensitive and reliable indicator for the measurement of thrombin activity, without day time intra-individual fluctuation (24). Increased levels of thrombin-antithrombin III have already been identified in various thrombo-embolic states, such as deep vein thrombosis, diffuse intravascular coagulation, coronary artery disease, as well as during pregnancy $(22,25-27)$. Thrombin-antithrombin III was also found to be increased after acute physical exercise, reflecting enhanced thrombin generation and thus a 
hypercoagulable post-exercise state $(23,28)$. In our study no increases in thrombin-antithrombin III concentrations were observed at the end of the training programme. Moreover, in the male population individually raised thrombin-antithrombin III levels before the training programme were returned to the reference range five days after the $21 \mathrm{~km}$ race, implicating a long term beneficial effect of physical exercise (29).

In summary, our study demonstrates that a physical fitness programe of increasing intensity, which induces physical and possibly mental stress, has significant effects on plasma fibrinogen concentration, even at rest. But, in contrast to acute post-exercise effects, this regular fitness programme did not induce an activation of the haemostatic system. 


\section{REFERENCES}

1. Alexander $S$. Physiologic and biochemical effects of exercise. Clin Biochem 1984; 17: 126-31.

2. Fletcher $G$. Long-term exercise in coronary artery disease and other chronic states. Heart Lung 1984; 13: 28-46.

3. Rudmann SV. The effects of exercise on haemostasis: a review of the literature and implications for research. $\mathrm{J}$ Med Technol 1987; 4: 215-7

4. Rizza CR. Effect of exercise on the level of antihaemophilic globulin in human blood. J physiol $1961 ; 156$ : $128-35$.

5. Stibbe $\mathrm{J}$. Effect of exercise on FVIII-complex: proportional increase of ristocetin cofactor (von Willebrand Factor) and FVIII-AGN, but disproportional increase of FVIII-AHF. Thromb Res 1977; 10: 163-8.

6. Andrew $M$, Carter $C$, $O^{\prime}$ Brodovich $H$, Heigenhauser $G$. Increases in factor VIII complex and fibrinolytic activity are dependent on exercise intensity. J Appl Physiol 1986; 60: 1917-22.

7. Jern C, Eriksson E, Tengborn L, Risberg B, Wadenwik H, Jern $S$. Changes of plasma coagulation and fibrinolysis in response to mental stress. Thromb Haemost $1989 ; 62$ : 767-71.

8. Bourney $\mathrm{RE}$, and Santoro SA. Interactions of exercise, coagulation, platelets, and fibrinolysis - a brief review. Med Sci Sports Exerc 1988; 20: 439-45.

9. Wheeler ME, Davis GL, Gillespie wJ, Bern MM. Physiological changes in haemostasis associated with acute exercise. J Appl Physiol 1986; 60:986-90.

10. Small M, Tweddel, Rankin AC. Blood coagulation and platelet function following maximal exercise: Effects of beta-adrenocepter blockade. Haemostasis $1984 ; 14$ : $262-8$.

11. Kopitsky RG, Switzer, williams RS, Mckee PA. The basis for the increase in factor VIII procoagulant activity during exercise. Thromb Haemostas 1983; 49: 534-7.

12. Watts EJ. Haemostatic changes in long-distance runners and their relevance to the prevention of ischaemic heart disease. Blood Coag Fibrinol 1991; 2 : 221-5.

13. Sinzinger $H$, Virgolini $I$. Effects of exercise on parameters of blood coagulation, platelet function and the prostaglandin system. Sports Med 1988; 6: 238-45.

14. Röcker L, Drygas WK, Heyduck B. Blood platelet activation and increase in thrombin activity following a marathon race. Eur J Appl Physiol 1986; 55: 374-80.

15. Arai M, Yorifuji H, Ikematsu S, Nagasawa H, Fujimaji M, Fukutake $K$, Katsumura $T$, Ishii $T$, Iwane $H$. Influences of strenuous exercise (triathlon) on blood coagulation and fibrinolytic system. Thromb Res 1990; 57: 465-71.

16. Taniguchi N, Hirohiko, Yamauchik. Effects of treadmill exercise on platelet functions and blood coagulating 
activities in healthy men. Jpn Heart $J$ 1984; 25: 16780 .

17. Janssen GME. Marathon running: functional changes in male and female subjects during training and contests. Int $J$ Sports Med 1989; 10 suppl3: 117-90.

18. Schneider SH, Kim HC, Kachaduzian AK, Ruderman NB. Impaired fibrinolytic response to exercise in type II diabetes: effects of exercise and physical training. Metabolism 1988; 37: 924-9.

19. Rosengren $A$, wilhelmsen $L$, welin $L$, TsipogianniA, Teger-Nilsson A, Wedel H. Social influences and cardiovascular risk factors as determinants of plasma fibrinogen concentration in a general population sample of middle aged men. Br Med J 1990; 300:634-8.

20. Meade $T W$, Imeson $J$, Stirling $Y$. Effects of changes in smoking and other characteristics on clotting factors and the risk of ischaemic heart disease. Lancet 1987; ii: $986-8$.

21. Stratton JR, Chandler WL, Scwartz RS, Cerqueira MD, Levey WC, Kahn SE, Larson VG, Cain KC, Beard JC, Abrass IB. Effects of physical conditioning on fibrinolytic variables and fibrinogen in young and old healthy adults. Phys Cond Fibrinol 1990; 83: 1692-7.

22. Ono $N$, Koyama $T$, Suerhiro A, Oku K, Fujikake K, Kakisha E. Clinical significance of new coagulation and fibrinolytic markers in ischemic stroke patients. Stroke 1991: 1369-73.

23. Bărtsch P, Haeberli A, straub PW. Blood coagulation after long distance running: antithrombin III prevents fibrin formation. Thromb Haemost $1990 ; 63$ : 430-4.

24. Deguchi $K$, Noguchi $M$, Yuwasaki $E$, Endou $T$, Deguchi $A$, Wada H, Murashima S, Nishikawa M, Shirakawa S, Tanaka $K$, Kusagawa M. Dynamic fluctuations in blood of thrombin/antithrombin III complex (TAT). Am J Hematol $1991 ; 38: 86-9$.

25. Hoek JA, sturk A, ten Cate JW, Lamping RJ, Berends $F$, Borm JJ. Laboratory and clinical evaluation of an assay of thrombin-antithrombin III complexes in plasma. Clin Chem 1988; 34: 2058-62.

26. Uno $M$, Hajime $T$, Masahiko $W$, Takada 0 , Kobayashi $K$, Takabuchi H, Shirai K, Sawada S, Toyoda T, Yamamoto K, Katoh $K$, Nakagawa $M$. Application of thrombinantithrombin III complex for detecting a latent hypercoagulable state in patients with coronary artery disease. Jpn Circ J 1989; 53: 1185-91.

27. Van Wersch JWJ, Ubachs JMH. Blood coagulation and fibrinolysis during normal pregnancy. Eur $\mathrm{J} \mathrm{Cl}$ in Chem Clin Biochem 1991; 29: 45-50.

28. Dufaux B, order U, Liesen H. Effects of a short maximal physical exercise on coagulation, fibrinolysis, and complement system. Int $J$ sports Med 1991; 12: 38-42.

29. Gris JP, Schved JF, Feugas O, Aguilar-Martinez P 
Arnaud A, Sanchez N, Sarlat C. Impact of smoking, physical training and weight reduction on FVII, PAI-1 and haemostatic markers in sedentary men. Thromb Haemost $1990 ; 64: 516-20$. 


\section{CHAPTER 6}

EFFECT OF LONG-TERM ENDURANCE EXERCISE ON

FIBRINOLYTIC MARKERS

G.A.E. Ponjee, G.M.E. Janssen, and J.W.J. van Wersch

Also published in:

Fibrinolysis 1993; 7 : 397-400.

(Reproduced with permission) 


\section{SUMRARY}

To study the long-term overall effect of habitual physical exercise on fibrinolysis, 20 sedentary males and 14 sedentary females were trained 3 to 4 times a week with increasing intensity during 9 months. After 24 and 36 weeks all subjects ran a $15 \mathrm{~km}$ and half marathon $(21 \mathrm{~km})$ race, respectively. Blood samples were drawn before the training programme, five days before both races and five days after the half marathon run. After the training period, plasma tissue-plasminogen activator antigen concentration was slightly decreased in both the male and female population. Plasma plasminogen activator inhibitor activity decreased significantly $(p<0.01)$ in both groups during the course of the training programme. No effect of increased fibrinolytic activity was observed, since plasma D-dimer concentrations were not changed after the test period.

In summary, the results of this study demonstrate that long-term physical conditioning leads to a marked decrease in plasminogen activator inhibitor activity, without an actual increase of fibrinolytic end products. 


\section{INTRODUCTION}

Since the first observations on fibrinolysis and exercise by Biggs in 1947 (1), numerous investigators confirmed that exercise will increase the fibrinolytic activity acutely in plasma of healthy individuals (2-10). The presumed antithrombotic effect of exercise has been a topic for clinical trials, correlating exercise with a reduced risk for cardiovascular disease (11-13). As a consequence, today an increasing number of people start to do sports regularly, in order to improve their physical fitness and to reduce their risk factor profile. Acute maximal and prolonged exercise activates the fibrinolytic potential by releasing tissue-plasminogen activator ( $t-\mathrm{PA})$ from the endothelial cells of blood vessels $(9,10,13-17$; Figure 1). Most studies are concerned with short-term changes after one workload in trained and untrained subjects $(3,4,8,9,13,17)$. Little attention has been paid to the adaptive fibrinolytic response of the body, following chronic prolonged physical activity and excluding acute post-exercise effects $(14,18)$. The purpose of the present study was therefore, to investigate longitudinally the long-term overall effect of physical exercise on fibrinolytic markers, such as tissue-plasminogen activator, plasminogen activator inhibitor and D-dimer.

\section{MATERIAL AND METHODS}

\section{Subjects}

Twenty males aged from 32 to 49 years (median:39) and 14 females aged from 27-41 years (median: 35) were selected from 370 people who replied to advertisements in two local newspapers and on a local radio station. Those who participated in any sports such as running or jogging or who were active for more than one hour per week in other recreational sports were excluded. After two information 


\section{Intrinelc activatora}

\section{ExtrInsic activators}

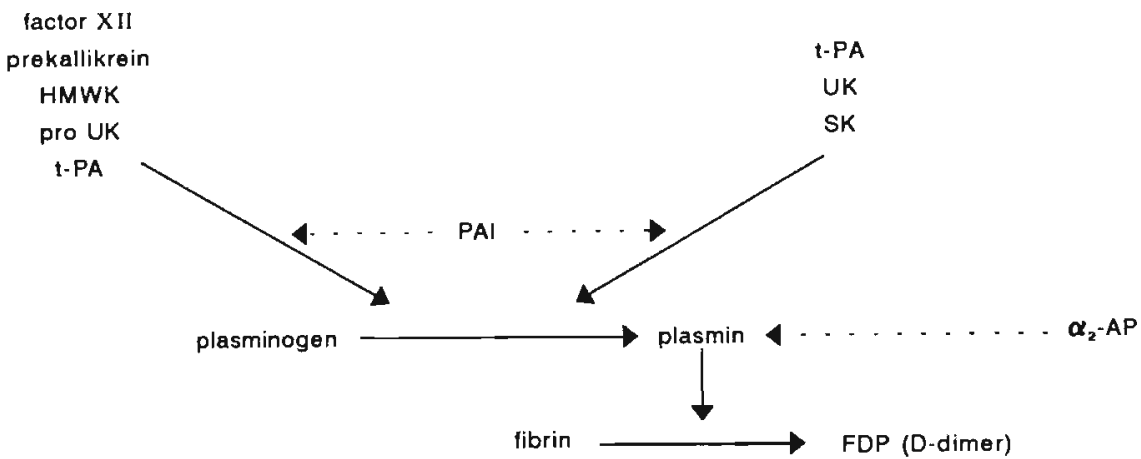

\section{Figure 1}

Scheme of fibrinolysis.

The dotted lines indicate inhibition.

HMWK = High Molecular Weight Kininogen; $t-\mathrm{PA}=t$ issuePlasminogen Activator; $\mathrm{UK}=$ Urokinase; $\mathrm{SK}=$ Streptokinase; $\mathrm{PAI}=$ Plasminogen Activator Inhibitor; $\alpha 2-\mathrm{AP}=\alpha 2-$ antiplasmin; FDP = Fibrin Degradation Products .

sessions all subjects gave their written informed consent. The median (interquartile range) body weight shifted in the male population from $74.6(69.1-79.8) \mathrm{kg}$ at start to 72.2 $(64.9-77.7) \mathrm{kg} \quad(\mathrm{p}<0.01)$ at the end of the training programme. In the female population from 63.0 (57.0-65.8) $\mathrm{kg}$ to $60.7(55.0-63.4) \mathrm{kg} \mathrm{(n.s.)}$.

The median (interquartile range) body mass index shifted in the male group from $23.1(21.6-25.5) \mathrm{kg} / \mathrm{m}^{2}$ to 22.0 (21.1 $24.4) \mathrm{kg} / \mathrm{m}^{2} \quad(\mathrm{p}<0.01)$ and in the female group from $21.6 \quad(21.3$ - 22.6$) \mathrm{kg} / \mathrm{m}^{2}$ to $21.5(21.3$ - 22.3$) \mathrm{kg} / \mathrm{m}^{2}$ (n.s.).

The median (interquartile range) serum triglyceride level in the male group was reduced from 1.11 (0.91 - 1.51) mmol/1 before the training programme to $0.92(0.77$ - 1.36) mmol/1 ( $p<0.01$ ) after the half marathon run. In females the median (interquartile range) value decreased from 0.89 $(0.65-1.14) \mathrm{mmol} / 1$ to $0.73(0.57$ - 1.11) mmol/l (n.s.). 


\section{Training programme}

After a medical examination and pre-exercise control measurements, all volunteers participated in a 9 month endurance training programme, preparing for a half marathon run $(21 \mathrm{~km})$. The schedule was essentially the same as previously described by Janssen et al (19). The training schedule consisted of 3 times a week supervised distance running on schedule and one supervised interval training with emphasis on the running technique. After 24 and 36 weeks all subjects ran a 14 and $21 \mathrm{~km}$ race, respectively.

\section{Blood samples}

All blood samples were drawn between 8.00 and 9.00 am, to avoid diurnal variation in fibrinolytic variables (20). Samples were taken before the start of the training programme, five days before both races as well as five days after the half marathon run. Non-traumatic venipuncture was performed and nine volumes of freshly drawn blood were mixed with one volume trisodium citrate $(0.11 \mathrm{~mol} / 1)$. After centrifugation for $30 \mathrm{~min}(3000 \mathrm{~g})$ at $4^{\circ} \mathrm{C}$, the plasma was snap-frozen in aliquots, stored at $-70^{\circ} \mathrm{C}$ in plastic tubes and thawed at $37^{\circ} \mathrm{C}$ immediately prior to serial analysis.

\section{Methods}

Tissue-plasminogen activator antigen (t-PA) concentrations $\langle\mu \mathrm{g} / \mathrm{l}\rangle$ and $\mathrm{D}$-dimer concentrations $(\mu \mathrm{g} / \mathrm{l})$ were determined in plasma by an ELISA method, according to the instructions of the manufacturer (Kabi Vitrum Diagnostica, Mölndal, Sweden and Boehringer Mannheim Corp., Mannheim, Germany, respectively). Intra-assay coefficient of variation was less than 5\% for both assays. Plasminogen activator inhibitor (PAI) activity was analyzed with a commercial test kit from Kabi Vitrum Diagnostica (Mölndal, Sweden), using excess single chain $t-P A$ and $S-2251$ as chromogenic substrate for plasmin. PAI activity is expressed in arbitrary units times $10^{3}$ per 1 (AU. $10^{3} / 1$ ); 1 AU equals the 
amount of PAI that neutralizes 1 IU of $t-P A$ under conditions instructed. Intra-assay coefficient of variation was less than $10 \%$. Reference ranges, determined in plasma of 50 healthy volunteers (males and females), were for $t-$ PA: $0.9-12.1 \mu \mathrm{g} / \mathrm{l}$ and for PAI: $10.7-32.7 \mathrm{AU} .10^{3} / 1$. The D-dimer reference values ranged from 37 to $373 \mu \mathrm{g} / \mathrm{l}$ for males and from 38 to $438 \mu \mathrm{g} / \mathrm{l}$ for females.

\section{statistics}

All statistics were calculated with SPSS/PC+ Statistics 4.0 statistical data analysis (SPSS Inc., Chicago, USA). wilcoxon signed rank test was used to compare differences in pre-, during and post-exercise plasma samples. The MannWhitney wilcoxon test was used to compare the male and female population. All data are given as medians and interquartile ranges.

\section{RESULTS}

Median (interquartile range) plasma $t-P A$ antigen concentrations, PAI activities and D-Dimer concentrations are summarized in Figures 2-4. The nine months training programme induced only a slight reduction in $t-P A$ antigen concentration in plasma of 15 males and 9 females. Median $t-P A$ level in the male group was reduced from $5.8 \mu \mathrm{g} / \mathrm{l}$ before the start of the training programme to $5.6 \mu \mathrm{g} / 1 \mathrm{nine}$ months later, a reduction of $3 \%$. In the female group median $t-P A$ level was reduced from $3.7 \mu \mathrm{g} / 1$ to $3.5 \mu \mathrm{g} / 1$ (-58). Median plasma PAI activity decreased significantly $(p<0.01)$ during the course of the training programme. Moreover, in both male and female group a marked reduction in median PAI levels was already noticed after 24 weeks of training and continued to decrease to below the reference range levels at the end of the test period. In the male group median PAI concentration was reduced from $22.5 \mathrm{AU} .10^{3} / 1$ before the training programme to $4.5 \mathrm{AU} .10^{3} / 1$ nine months later, a 
reduction of $80 \%$. In the female group median PAI level was reduced from $18.7 \mathrm{AU} .10^{3} / 1$ to $5.1 \mathrm{AU} \cdot 10^{3} / 1(-73 \%)$. Finally, a small and non significant increase in median D-dimer concentration was observed after the start of the training programme, and this reduced to pre-training values in the course of the programme. Median D-dimer levels in the female group were consistently increased in comparison to those in the male population.

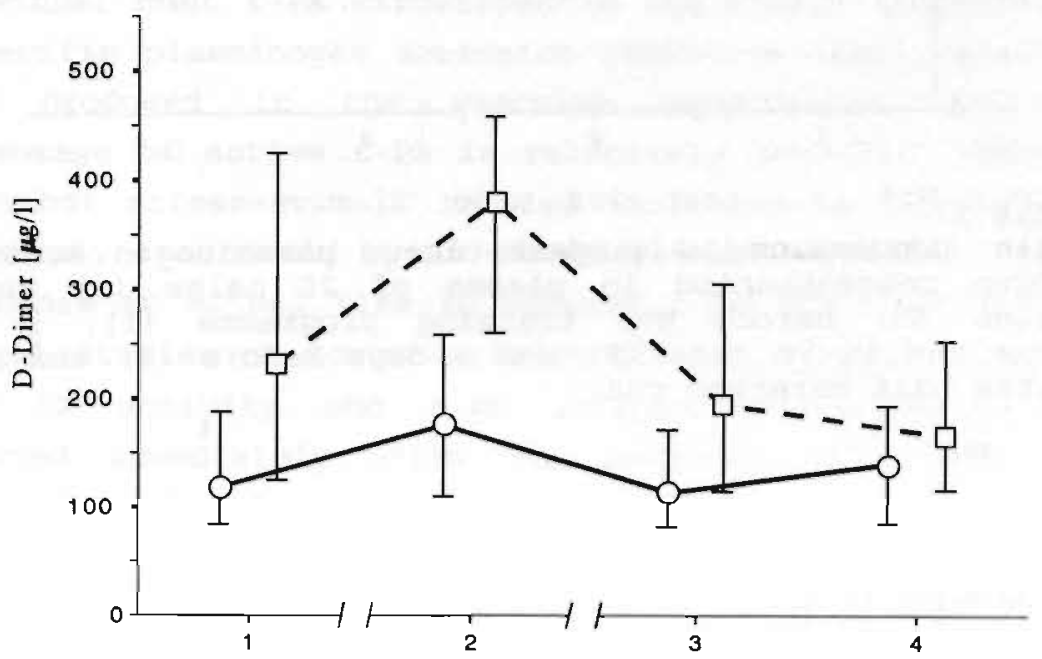

\section{Figure 2}

Median (interquartile ranges) D-dimer concentration ( $\mu \mathrm{g} / 1$ ) in plasma of 20 males (O) and 14 females ( $\square$ ) before the training programme (1), 5 days before the $15 \mathrm{~km}$ race (2) and 5 days before (3) and after (4) the half marathon run.

\section{DISCUSSION}

It is well known that short-term and prolonged physical exercise increases plasma fibrinolytic activity. This increase is directly related to the workload and duration of the exercise $(2,3)$, and has been attributed to the 


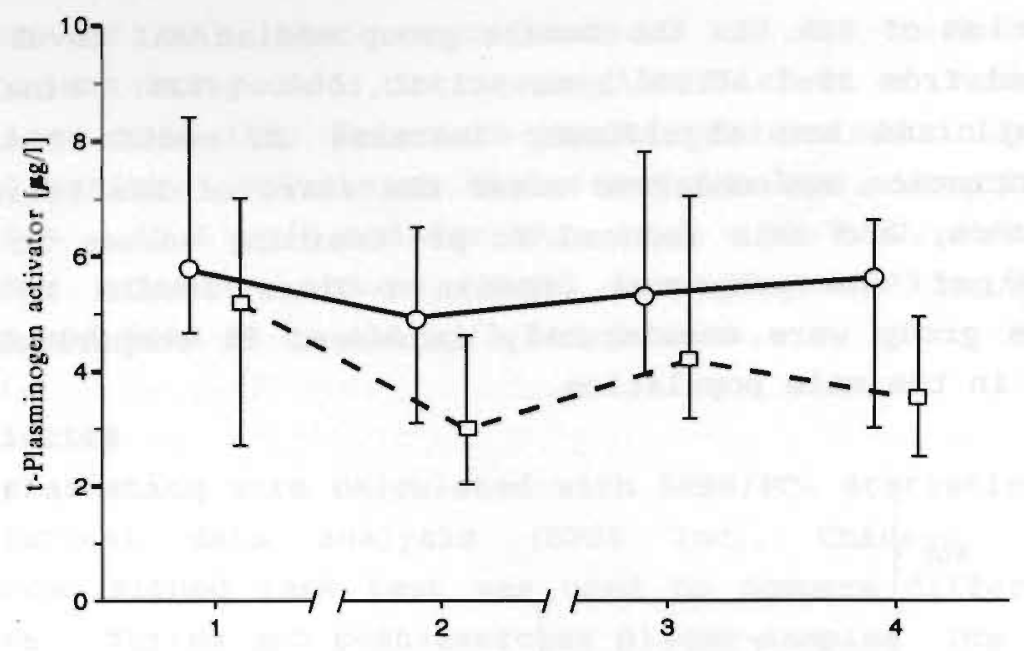

Figure 3

Median (interquartile ranges) tissue plasminogen activator antigen concentration in plasma of 20 males (0) and 14 females ( $\square$ ) before the training programme (1), 5 days before the $15 \mathrm{~km}$ race (2) and 5 days before (3) and after (4) the half marathon run.

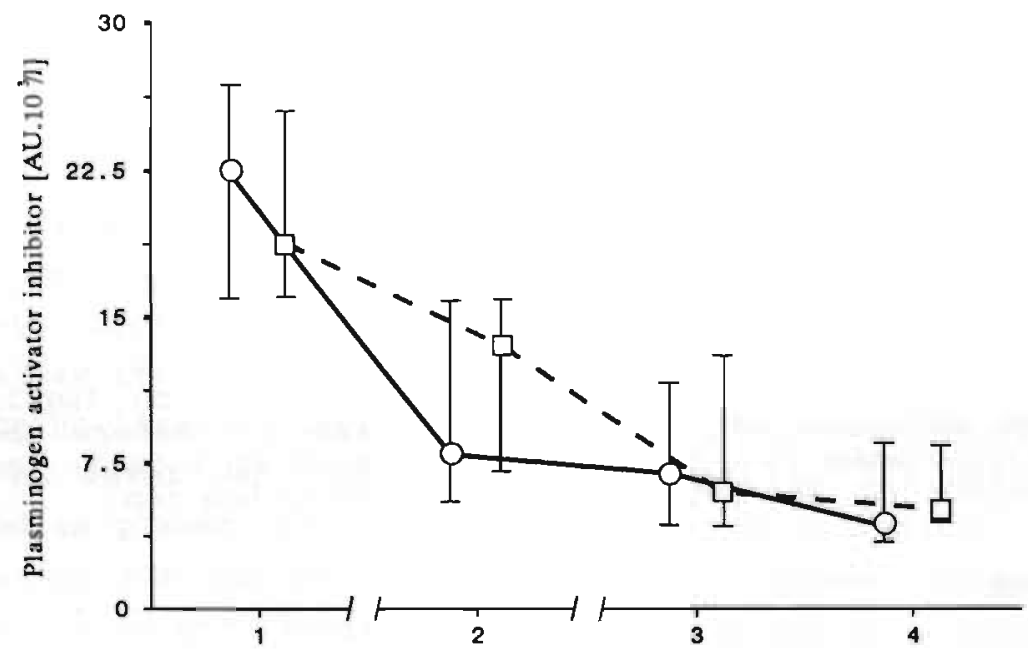

Figure 4

Median (interquartile ranges) plasminogen activator inhibitor activity $\left(\mathrm{AU} .10^{3} / 1\right)$ concentration in plasma of 20 males (O) and 14 females ( $\square$ ) before the training programme (1), 5 days before the $15 \mathrm{~km}$ race (2) and 5 days before (3) and after (4) the half marathon run. 
release of tissue-type plasminogen activator ( $t-P A$ ) from the vascular endothelium during and immediately after exercise $(9,10,13-17)$. The exercise induced release of $t-P A$ is not fully understood, but some of the contributing factors may be an enhanced blood flow (22) and elevated plasma arginine vasopressin concentration (8). other stimuli, like mental stress, adrenalin or vasopressin infusion and venous occlusion, provoke a similar release of $t-P A$ from the vessel wall $(6,8,22)$. In the resting individual most $t-P A$ circulates in the blood, complexed to a specific plasminogen activator inhibitor (PAI), which is also produced in the vascular endothelium, and the percentage of active $t-P A$ is relatively low (23). Exercise and other stress-stimuli related increases in fibrinolytic potential, are caused by an excess release of $t-P A$ over PAI and hence an actual rise in unbound $t-P A(10,13,22,23)$. In several studies on acute exercise effects, marked increases in $t-P A$ activity and $t-P A$ antigen concentration were observed immediately after the exercise peak, but both returned to baseline levels within 60 min to a few hours $(9,10,13,16)$. In the present long-term study, no increase in plasma $t-P A$ antigen concentration was found. In a comparable longitudinal study (14), a significant reduction in plasma $t-P A$ antigen concentration of an elderly male population was observed after six months of training. others noticed a significant lower resting $t-P A$ antigen level in trained subjects in comparison to age matched sedentary controls (13). Already after 24 weeks of regular physical exercise, plasma PAI activity was significantly ( $p<0.01$ ) lowered in both male and female group and continued to diminish to below reference value levels after nine months. Increased PAI levels are observed in several patient populations, including patients suffering from cardiovascular disease $(13,24-27)$. Therefore elevated PAI levels are supposed to be an independent risk factor for cardiovascular disease $(28,29)$ and peak PAI levels are 
observed to coincide with myocardial infarction (30). The average fraction of active $t-P A$ is strongly correlated with a reduction in PAI concentration (23). The marked reduction of PAI activity, observed in this study, is also found by others $(13,14,18)$ and can be considered as a beneficial outcome of physical conditioning. In the present study the PAI decrease seems not to be strongly correlated to changes in body weight, body mass index nor serum triglycerides, because only a significant reduction in serum triglycerides in the male population at the end of the training period was found. Some authors doubt whether the exercise induced release of $t-P A$ causes an effective fibrinolysis in vivo, since no post-exercise increase in fibrin(ogen) degradation products was observed $(5,13)$, while others did find an acute post-exercise elevation of fibrin(ogen) breakdown products $(7,10,16)$. In this study, also no shift in the fibrinolytic end products in rest after prolonged physical conditioning was observed, since D-dimer concentrations remained essentially unchanged. This finding might indicate that in the long-term, no increase in fibrin formation rate occurs, because t-PA activates plasminogen only effectively in the presence of fibrin. The increased median D-dimer concentrations of the female group during this study, in comparison with the median D-dimer concentrations of the male group, were also noticed when the reference values were determined. This increase in basal fibrinolytic activity, can be induced by oral contraceptives, which were used by most women, since this medication is supposed to have a potentiating effect on haemostatic as well as fibrinolytic activity $(31,32)$.

In summary, from the results of this study we can conclude that long-term physical conditioning is associated with a predominant reduction of plasma PAI activity. This finding might be considered as a positive effect of long-term endurance exercise on the risk reduction for cardiovascular disease. 


\section{REFERENCES}

1. Biggs R, Macfarlane RG. Observations on fibrinolysis. Experimental activity produced by exercise of adrenaline. Lancet 1947: 402-406.

2. Rosing DR, Brakman P, Redwood DR, Goldstein RE, Beiser GD, Epstein E. Blood fibrinolytic activity in man. Diurnal variation and the response to varying intensities of exercise. Circ Res XXVII 1970: 171-184.

3. Davis GL, Abildgaard CF, Bernauer EM, Britton $M$. Fibrinolytic and haemostatic changes during and after maximal exercise in males. J Appl Physiol 1976; 40: 287-92.

4. Mandalaki T, Dessypris A, Louizou C, Panayotopoulou C, Dimitriadou C. Marathon Run III: Effects on coagulation, fibrinolysis, platelet aggregation and serum cortisol levels. A 3-year study. Tromb Haemost $1980: 49-52$.

5. Marsh NA, Gaffney PJ. Exercise-induced fibrinolysis Fact or fiction? Thromb Heamost 1982; 48: 201-3.

6. Williams RS, Everett EL, Lewis JL, Barton $T$, stead NW, Wallace $A G$, Pizzo Sv. Physical conditioning augments the fibrinolytic response to venous occlusion in healthy adults. N Engl J Med 1980; 302: 987-91.

7. Ferguson EW, Bernier LL, Banta GR, Yu-Yahiro J, Schoomaker EB Effects of exercise and conditioning on clotting and fibrinolytic activity in men. J Appl Physiol 1987; 62: 1416-21.

8. El-Sayed MS. Exercise intensity-related responses of fibrinolytic activity and vasopressin in man. Med Sci Sports Exerc 1990; 22: 494-500.

9. Hansen JB, Wilsgard L, Olsen JO, Osterud B. Formation and persistence of procoagulant and fibrinolytic activities in circulation after strenuous physical exercise. Thromb Heamost 1990; 64: 385-9.

10. Röcker L, Taenzer $M$, Drygas WK, Lill $H$, Heyduck B, Altenkrich HU. Effect of prolonged physical exercise on the fibxinolytic system. Eur J Appl Physiol 1990; 60: $478-81$.

11. Paffenbarger RS, Hyde RT, wing AL, Hsieh CC. Physical activity, all-cause mortality, and longevity of college alumni. Nw Eng J Med 1986; 314: 605-13.

12. Blair SN, Kohl HW, Paffenbarger RS, Clark DG, Cooper $\mathrm{KH}$, Gibborns LW. Physical fitness and all-cause mortality. A prospective study of healthy men and women. JAMA 1989; 262: 2395-401.

13. Speiser $W$, Langer $W$, Pschaick A, Selmayr E, Ibe $B$, Nowacki PE, Muller-Berghaus G. Increased blood fibrinolytic activity after physical exercise: comparative study in individuals with different sporting activities and in patients after myocardial infarction taking part in a rehabilitation sports program. Thromb Res 1988; 51: 543-55. 
14. Stratton JR, Chandler WL, Schwartz RS, Cerqueria MD, Levy WC, Kahn SE, Larson VG, Cain KC, Beard JC, Abrass IB. Effects of physical conditioning on fibrinolytic variables and fibrinogen in young and old healthy adul.ts. Circulation 1991; 83: 1692-97.

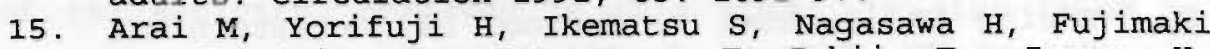
$M$, Fukutake $K$, Katsumura $T$ Ishii $T$, Iwane $H$. Influences of strenuous exercise (triathlon) on blood coagulation and fibrinolytic system. Thromb Res 1990; 57: 465-71.

16. Dufaux B, order U, Liesen $H$. Effect of a short maximal physical exercise on coagulation, fibrinolysis, and complement system. Int J Sports Med 1991; 12: S38-S42.

17. Gough SCL, whitworth S, Rice PJS, Grant PJ. The effect of exercise and heart rate on fibrinolytic activity. Bl Coagul Fibrinol 1992; 3: 179-82.

18. Gris JC, Schved JF, Feugeas O, Aguilar-Martines P, Arnaud A, Sanchez N, Sarlat Ch. Impact of smoking, physical training and weight reduction on FVII and haemostatic markers in sedentary men. Thromb Haemost: $1990 ; 64$ (4): 516-20.

19. Janssen GME. Marathon running: functional changes in male and female subjects during training and contests. Int J Sports Med 10 suppl 1989; 13: 117-90.

20. Angleton $P$, Chandler WL, Schmer G. Diurnal variation of tissue plasminogen activator ( $t-P A)$ and its rapid inhibitor (PAI-1). Circulation 1989; 79: 101-6.

21. Rennie JAN, Bennett B, Ogston D. Effect of local exercise and vessel occlusion on fibrinolytic activity. J Clin Path 1977; 30: 350-2.

22. Jern C, Eriksson E, Tengborn L, Risberg B, Wadenvik $H$, Jern $S$. Changes of plasma coagulation and fibrinolysis in response to mental stress. Thromb Haemost $1989 ; 62$ : 767-71.

23. Chandler WL, Trimble SL, Loo S-C, Mornin D. Effect of PAI-1 levels on the molar concentrations of active tissue plasminogen activator $(t-P A)$ and $t-P A / P A I-I$ complex in plasma. Blood 1990; 76: 930-7.

24. Estelles A, Aznar J, Tormo G, Sapena P, Tormo V, Espana F. Influence of a rehabilitation sports programme on the fibrinolytic activity of patients after myocardial infarction. Thromb Res 1989; 55: 20312 .

25. Rydzewski A, Sakata K, Kobayashi A, Yamazaki N, Urano $T$, Takada $Y$, Takada $A$. Changes in plasminogen activator inhibitor 1 and tissue-type plasminogen activator during exercise in patients with coronary artery disease. Haemostasis 1990; 20: 305-12.

26. Pietraszek MH, Serizawa K, Takada Y, Takada A. Effect of acute alcohol ingestion on the fibrinolytic activity. Fibrinolysis 1991; 5: 249-52.

27. Philippe J, offner F, Declerck PJ, Leroux-Roels $G$, vogelaers D, Baele G, Collen D. Fibrinolyis and 
coagulation in patients with infectious disease and sepsis. Thromb Haemost 1991; 65: 291-5.

28. Paramo JA, Colucci M, Collen D. Plasminogen activator inhibitor in the blood of patients with coronary artery disease. BMJ 1985; 291: 573-4.

29. Hamsten A, De Faire U, Walldius G, Dahlen G, Szamosi $A$, Landou C, Blomback M, Wiman B. Plasminogen activator inhibitor in plasma: risk factor for recurrent myocardial infarction. Lancet $1987 ; 2: 3-9$.

30. Sakata $K$, Kurata $C$, Taguchi $T$, Hayashi $H$, Kobayashi $A$, Yamazaki N, Rydzewski A, Takada A. The role of the fibrinolytic system in acute myocardial infarction after a normal exercise test. Eur Heart J 1989; 10: $1118-22$.

31. Hedlin AM, Milojevic S, Korey A. Haemostatic changes induced by exercise during oral contra conceptive use. Can J Physiol Pharmacol 1978; 56: 316-20.

32. Huisveld IA, Hospers JEH, Berrnink MJE, Erich WBM, Bouma BN. The effect of oral contraceptives and exercise on haemostatic and fibrinolytic mechanisms in trained women. Int J Sports Med 1983; 4: 97-103. 
Exercise and Eibrinolysis 


\section{CHAPTER 7}

PROLONGED PHYSICAL CONDITIONING AND BLOOD PLATELET

RELEASE MARKERS: A LONGITUDINAL STUDY

G.A.E. Ponjee, G.M.E. Janssen and J.W.J. van Wersch

Also published in:

Haemostasis 1993; $23: 269-274$.

(Reproduced with permission) 


\section{SULMARY}

To study the long-term non acute effect of endurance physical exercise on blood platelet activation, 20 sedentary males and 14 sedentary females were trained 3 to 4 times a week for 9 months. After 24 weeks all subjects ran a $15 \mathrm{~km}$ race; and after 36 weeks a half marathon (21 $\mathrm{km})$ race. Blood samples were drawn before the training programme and five days before both races. Median (interquartile range) platelet factor 4 and betathromboglobulin pre-training values for the total group were $9(5-35) \mathrm{IU} / \mathrm{ml}$ and 69 (40-495) IU/ml, respectively. During the course of the training programme, plasma platelet factor 4 concentrations rose steadily and significantly in both the male and female group $(p<0.05)$, together with a non-significant rise in plasma betathromboglobulin. At the end of the training procedure, five days before the half marathon run, median (interquartile range) plasma factor 4 and beta-thromboglobulin concentrations for the total group were $150(62-198) \mathrm{IU} / \mathrm{ml}$ and 156 (84-288) IU/ml, respectively. No difference existed in median platelet factor 4 and beta-thromboglobulin concentrations of the male and female population before or during the training programme. In summary, the results of this study demonstrate that prolonged physical conditioning of increasing intensity is associated with mainly an elevation of the plasma level of platelet factor 4. 


\section{INTRODUCTION}

At present there is a general consensus that people in all age groups should regularly perform physical exercise for general health $(1,2)$. However, some reports have shown that strenuous exertion is associated with ischemic cardiac events $(3,4)$. The pathogenesis of myocardial ischemia may be related to blood platelet activation and therefore the response of platelets to exercise is of great physiological interest (5-11). It is well known that acute exercise induces a transient increase in platelet count, caused by a release of thrombocytes from the spleen and from other sites of temporary trapping such as the pulmonary circulation (12-14). Equivocal data were obtained from platelet aggregation studies with in vitro techniques $(6,10,15-17)$. Conflicting results also exist on acute or prolonged exercise induced platelet activation, measured by in vivo indicators of platelet activation, like platelet factor 4 and beta-thromboglobulin (7-11,18-23). These proteins are platelet specific and released from the alpha granules during platelet activation (18). A schematic representation of the platelet structure is shown in Figure 1. The major discrepancies between the studies concerned are the nature of the physical exercise performed, mainly limited to one workload of different intensities in trained or untrained individuals and the method used to assess platelet activation. Only few data exist on prolonged physical conditioning and blood platelet aggregability $(24,25)$.

The objective of this investigation was to determine the effect of long-term physical conditioning on blood platelet activation by measuring the circulating levels of platelet factor 4 and beta-thromboglobulin. 


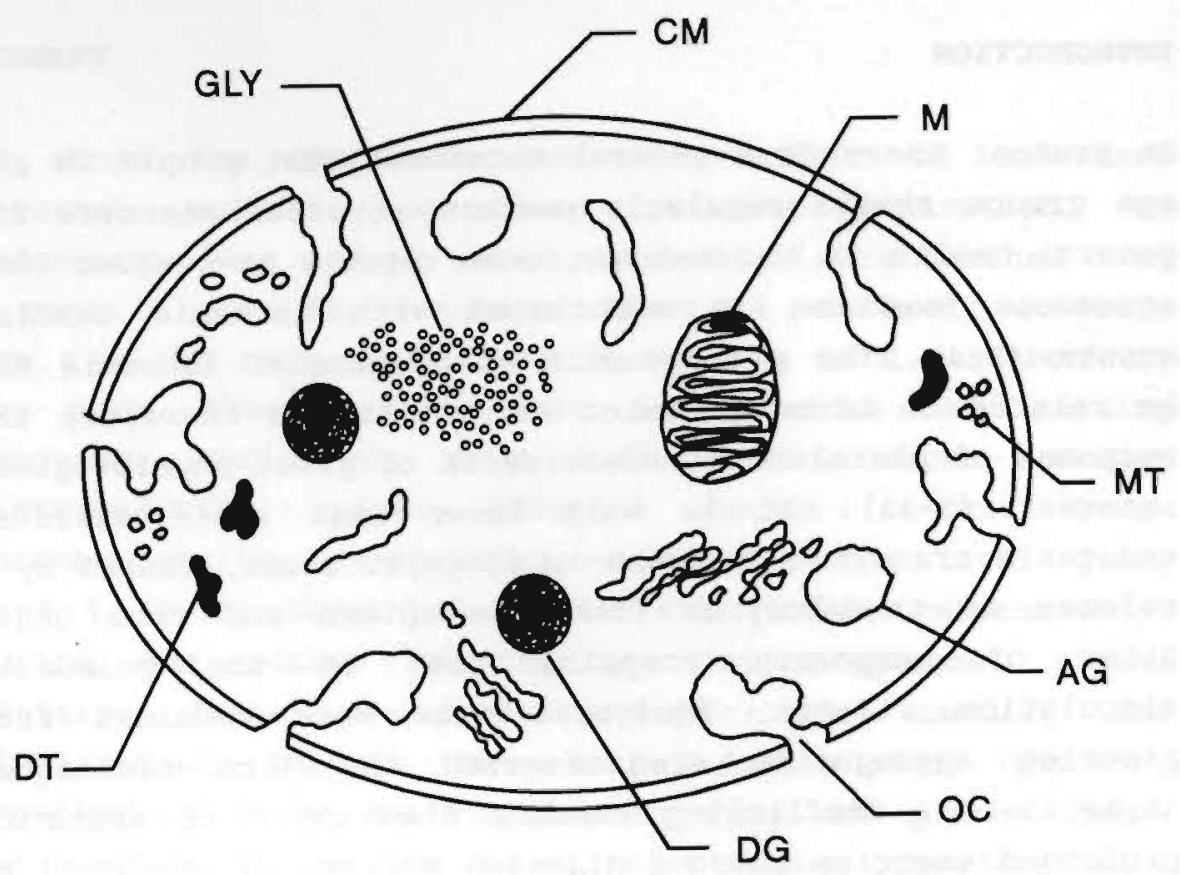

Figure 1

A schematic representation of the platelet structure.

$\mathrm{Gly}=$ glycogen; $\mathrm{CM}=$ cell membrane; $\mathrm{M}=$ mitochondria; $\mathrm{MT}=$ microtubuli; $\mathrm{DT}=$ dense tubuli; $\mathrm{DG}=$ dense granules; $\mathrm{AG}=$ alfa granules; $O C=$ open canalicular system.

\section{MATERIAL AND METHODS}

\section{subjects}

Twenty males aged from 32 to 49 years (median:39) and 14 females aged from 27-41 years (median: 35) were selected from 370 people who replied to advertisements in two local newspapers and on a local radio station. Those who participated in any sports such as running or jogging or who were active for more than one hour per week in other recreational sports were excluded. After two information sessions, all subjects gave their written informed consent. 
Training programme

After a medical examination and pre-exercise control measurements, all volunteers participated in a 9 month endurance training programme preparing for a half marathon run $(21 \mathrm{~km})$. The schedule was essentially the same as previously described by Janssen et al (26). The training schedule consisted of 3 times a week supervised distance running on schedule and one supervised interval training, with emphasis on the running technique. After 24 and 36 weeks all subjects ran a 15 and $21 \mathrm{~km}$ race, respectively.

\section{Blood samples}

All blood samples were drawn between 8.00 and $9.00 \mathrm{am}$, to avoid diurnal variation $(5,27)$. Samples were taken before the start of the training programme, and to avoid acute effects, five days before the 15 and $21 \mathrm{~km}$ race. Nontraumatic venipuncture was performed by trained operators. After discarding the first two $\mathrm{ml}, 4.5 \mathrm{ml}$ of blood were drawn into citric acid, theophylline, adenosine and dipyridamole containing test tubes (Boehringer Mannheim Corp., Mannheim, Germany) and immediately kept on ice. Within one hour from sample collection, all test tubes were centrifuged for $30 \mathrm{~min}(3000 \mathrm{~g})$ at $4^{\circ} \mathrm{C}$. Platelet poor plasma was slowly and gently aspirated from the central part of the plasma, without disturbing either the top layer or buffy coat. The plasma was snap-frozen in aliquots, stored at $-70^{\circ} \mathrm{C}$ in plastic tubes and thawed at $37^{\circ} \mathrm{C}$ immediately prior to serial analysis.

\section{Methods}

Plasma platelet factor 4 and beta-thromboglobulin concentrations were determined by an ELISA method according to the instructions of the manufacturer (Boehringer Mannheim Corp.). Platelet factor 4 and beta-thromboglobulin standards were standardized against the First National Standards, $83 / 505$ and $83 / 501$, respectively. Intra-assay 
coefficient of variation was between 5-108 for both assays.

\section{statistics}

All statistics were calculated with SPSS/PC+ Statistics 4.0 statistical data analysis (SPSS Inc., Chicago, USA). wilcoxon signed rank test was used to compare differences in pre-, during and post-exercise plasma samples. The MannWhitney wilcoxon test was used to compare the male and female population. All data are given as medians and interquartile ranges.

\section{RESULTS}

Median (interquartile range) plasma platelet factor 4 and beta-thromboglobulin concentrations are summarized in Figures 2 and 3 . Median (interquartile range) platelet factor 4 and beta-thromboglobulin pre-training values for the total group were $9(5-35) \mathrm{IU} / \mathrm{ml}$ and $69(40-495) \mathrm{IU} / \mathrm{ml}$, respectively. During the course of the training programme plasma platelet factor 4 concentrations rose significantly in both male and female group ( $<<0.05)$, together with a non-significant rise in plasma beta-thromboglobulin. At the end of the trainingprogramme, five days before the half marathon run, median (interquartile range) platelet factor 4 for the total group was $150(62-198) \mathrm{IU} / \mathrm{ml}$ and median (interquartile range) beta-thromboglobulin was 156 (84-288) $I U / \mathrm{ml}$. No gender related difference existed in median platelet factor 4 and beta-thromboglobulin concentrations of the male and female population at the start or in the course of the training programme.

\section{DISCUSSION}

Although platelets play an important role in normal haemostasis, a number of recent investigations emphasize the function of blood platelets in the pathogenesis of 


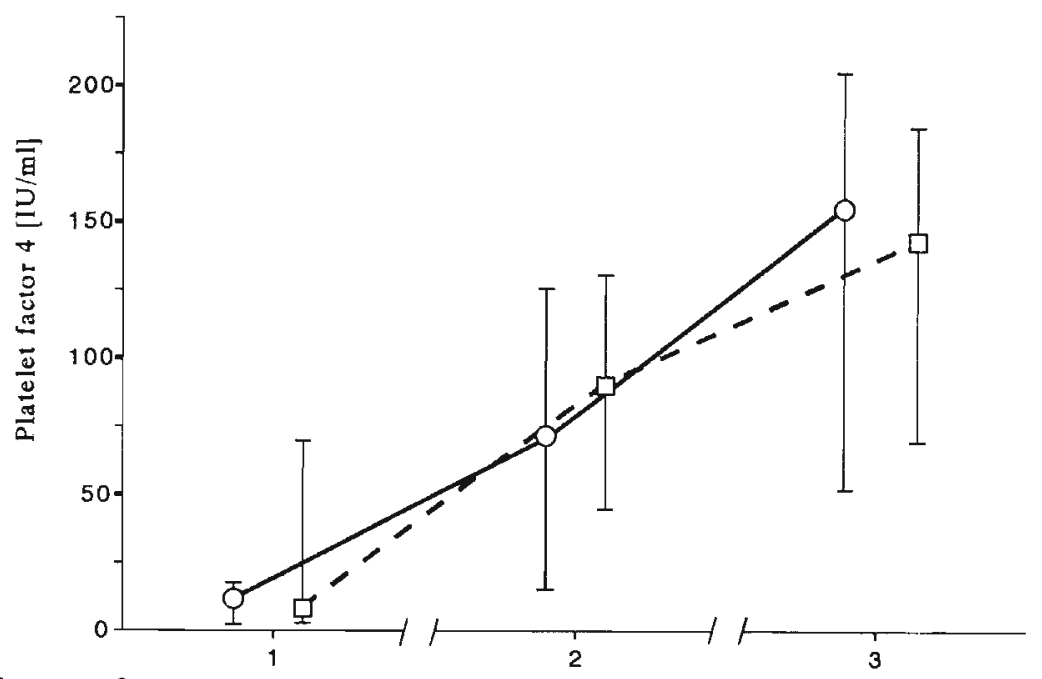

Figure 2

Median (interquartile ranges) platelet factor 4 concentration ( $\mathrm{IU} / \mathrm{ml}$ ) in plasma of 20 males (o) and 14 females ( $\square$ ) before the training programme (1) and 5 days before the $15 \mathrm{~km}$ (2) and $21 \mathrm{~km}$ (3) races, respectively.

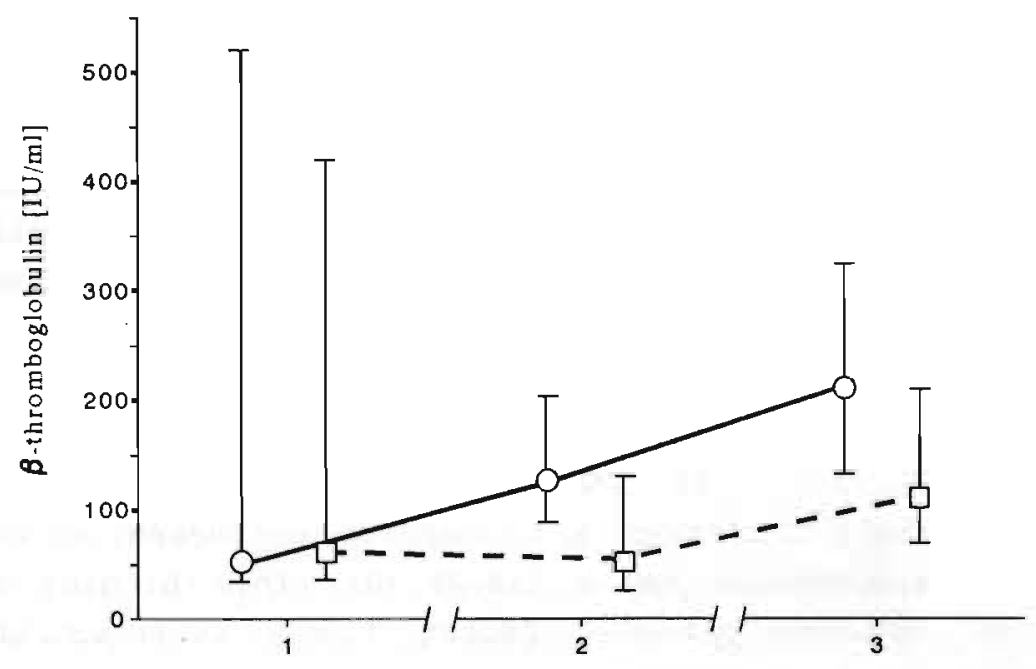

Figure 3

Median

(interquartile ranges) beta-thromboglobulin concentration (IU/ml) in plasma of 20 males (0) and 14 females ( $\square$ ) before the training programme (1) and 5 days before the $15 \mathrm{~km}$ (2) and $21 \mathrm{~km}$ (3) races, respectively. 
myocardial ischemia $(5,10,11,27)$. Since many healthy persons and also coronary patients, are taking part in sports programs, a major issue is whether exercise induces platelet hyperreactivity (6-11,15-17). After vigorous short-term exercise, blood platelet concentration and mean platelet volume increase, probably caused by newly released thrombocytes from platelet stores, like the spleen and pulmonary bed $(12-14)$. These alterations have not been observed after prolonged and regular activities $(24,25)$. studies on exercise induced hyperaggregability of blood platelets with in-vitro techniques, have shown conflicting results, which are at least partially due to differences in workload, fitness level of the subjects and timing of the blood sampling $(6-17)$. Furthermore, aggregation tests have their limitations, while measurement of released platelet proteins, like platelet factor 4 and beta-thromboglobulin, are better markers for platelet activation in-vivo $(18,19,28)$. Platelet factor 4 and beta-thromboglobulin are platelet specific proteins, which are released from alpha granules during platelet activation $(18,28)$. Although these proteins are markedly similar in structure, they differ considerably in biological properties $(18,28,29)$. Platelet factor 4 binds strongly to heparin and heparin-like molecules, whereas beta-thromboglobulin has only a low anti-heparin activity $(18,29,30)$. The rapid clearance of platelet factor 4 from the circulation, in contrast to beta-thromboglobulin, is supposed to be caused by the binding of platelet factor 4 to heparan sulphates at the surface of endothelial cells $(18,29,30)$. This binding is reversible, because platelet factor 4 may re-enter the circulation upon injection of heparin $(18,28,29)$. The interpretation of measured concentrations of platelet secreted proteins is rather difficult, due to potential artificial elevations that might occur during blood collection and sample preparation $(18,19,21)$. To distinguish between in-vitro and in-vivo secretion, some 
authors suggest that plasma platelet factor 4 and betathromboglobulin need to be evaluated together $(15,18)$. Because of the difference in clearance rate, plasma of healthy individuals at rest contains several times higher beta-thromboglobulin levels than platelet factor 4 levels, although both are released in equal amounts from the alpha granulae $(18,25)$. In the present study, the median plasma beta-thromboglobulin concentration in the total group was indeed substantially higher than the median platelet factor 4 concentration at the start of the training programme. Five days before the $15 \mathrm{~km}$ and $21 \mathrm{~km}$ race, 21 and 36 weeks after the beginning of the training programme, respectively, the median platelet factor 4 concentration was significantly increased ( $p<0.05)$ in comparison with pre-training levels in both the male and female group, whereas the rise of the median beta-thromboglobulin concentration was not significant. Although in-vitro activation cannot be ruled out totally, such an effect is very unlikely, because the data show consistently increasing values of the platelet proteins during the course of the programme. Some authors report a significant rise of platelet factor 4 and beta-thromboglobulin in plasma of healthy individuals and coronary patients immediately after exercise (8-11,17), implicating an acute post-exercise in-vivo platelet activation, although no correlation was found between the increase of platelet proteins and exexcise induced myocardial ischemia $(7,8,19)$. other investigators doubt whether an exercise induced increase of platelet proteins really exists $(20,22,30)$. Platelet activation is related to exercise intensity and duration, which might be partially responsible for these conflicting data $(22,23)$. In one study, a decreased platelet count was observed after one year of training of previously sedentary individuals, but one week after running a marathon race, platelet count was still enhanced in the same subjects in comparison with pre-training levels 
(25). This elevation gave information about the degree of recovery after strenuous exercise and was supposed to be caused by physical stress induced release of fresh platelets from a platelet pool.

Both an increased platelet number and a younger platelet population can be responsible for the elevated levels of platelet factor 4 and to a lesser degree betathromboglobulin, observed in our study 5 days before both races. The seeming discrepancy between the behaviour of platelet factor 4 and beta-thromboglobulin remains however, at first sight. But in a study measuring endogenous glycosaminoglycans after graded physical exercise, a significant increase of heparin-like activity in plasma of individuals during exercise and recovery was observed (31). This is an interesting finding, because several authors demonstrated the existence of a heparin-mobilizable pool of platelet factor 4, bound to the vascular endothelium $(18,28,29,32)$. Considering these observations, it seems possible that a certain amount of the risen concentration of platelet factor 4 , in the course of the training programme, measured in the present study, is not derived from activating platelets but from the heparin-mobilizable pool of platelet factor 4. This might partly be a plausible explanation for the divergence between platelet factor 4 and beta-thromboglobulin behaviour, seen in the present study.

In summary, physical conditioning of increasing intensity induces mainly an increased release of platelet factor 4 and to a lesser degree, of beta-thromboglobulin. Whether the significant rise in platelet factor 4 is caused by the release of platelet factor 4 from the vascular endothelium due to exercise induced increase in endogenous heparin-like substances, needs further investigation. 
1. Blair SN, Kohl HW, Paffenbarger RS, Clark DG, Cooper KH, Gibbone LW. Physical fitness and all-cause mortality. JAMA 1989; 262: 2395-401.

2. Paffenbarger RS, Hyde RT, Wing ALL, Hsieh C. Physical activity, all-cause mortality, and longevity of college alumni. Nw Eng J Med 1986; 314: 605-13.

3. Thompson PD, Funk EJ, Carleton RA, Sturner WQ. Incidence of death during jogging in Rhode island from 1975 through 1980. JAMA 1982; 247: 2535-8.

4. Powell KE, Thompson PD, Caspersen CJ, Kendrick JS. Physical activity and the incidence of coronary heartdisease. Ann Rev Public Health 1987; 8: 253-87.

5. Tofler GH, Brezinski D, Schafer AI, Czeisler CA, Willich SN, Rutherford JD, Gleason RE, Williams GH, Muller JE. Concurrent morning increase in platelet aggregability and the risk of myocardial infarction and sudden cardiac death. N Eng $J$ Med 1987; 316: 1514-8.

6. Dimitriadou C, Dessypris A, Louizou C, Mandalaki T. Marathon run II: Effects on platelet aggregation. Thromb Haemostas 1977; 37: 451-5.

7. Stratton JR, Malpass TW, Ritchie JL, Pfeifer MA, Harker LA, Studies of platelet factor 4 and beta thromboglobulin release during exercise: Lack of relationship to myocardial ischemia. Circulation $1982 ; 66: 33-43$.

8. Schernthaner G, Mühlhauser I, Böhm H, Seebacher C, Laimer $H$. Exercise induces in vivo platelet activation in patients with coronary artery disease and in healthy individuals. Haemostasis 1983; 13: $351-7$.

9. Röcker L, Drygas WK, Heyduck B. Blood platelet activation and increase in thrombin activity following a marathon race. Eur J Appl Physiol 1986; 55: $374-80$.

10. Mehta J, Mehta P. Comparison of platelet function during exercise in normal subjects and coronary artery disease patients: Potential role of platelet activation in myocardial ischemia. Am Heart J 1982 ; 103: 49-53.

11. Levine SP, Suarez AJ, Sorenson RR, Raymond NM, Knieriem LK. Platelet factor 4 release during exercise in patients with coronary artery disease. Am J Hematol 1984; 17: 117-27.

12. Peatfield RC, Gawel MJ, Clifford-Rose F, Guthrie DL, pearson TC. The effects of exercise on platelet numbers and size. Med Lab Sci 1985; 42: 40-3.

13. Schmidt KG, Rasmussen JW. Exercise-induced changes in the in vivo distribution of In-labelled platelets. Scand J Haematol 1984; 32 : 159-66.

14. Ohri VC, Chatterji JC, Das BK, Akhtar M, Tewari SC, 
Bhattacharji P, Behl A. Effect of submaximal exercise on haematocrit, platelet count, platelet aggregation and blood fibrinogen levels. J Sports Med 1983; 23: 127-30.

15. Piret A, Niset $G$, Depiesse $E$, Wyns $W$, Boeynaems JM, Poortmans $J$, Degre $S$. Increased platelet aggregability and prostacyclin biosynthesis induced by intense physical exercise. Thromb Res 1990; 57: 685-95.

16. Watts EJ, Weir P. Reduced platelet aggregation in long-distance runners. Lancet 1989 ; $i$ : 1013.

17. Knudsen JB, Brodthagen U, Gormsen $J$, Jordal $R$, Norregaard-Hansen $\mathrm{K}$, Paulev PE. Platelet function and fibrinolytic activity following distance running. Scan J Haematol 1982; 29: 425-30.

18. Kaplan KL, Owen J. Plasma Levels of B-thromboglobulin and platelet factor 4 as indices of platelet activation in vivo. J Am Soc Hematol 1981; 57: 199202.

19. Strauss WE, Cella G, Parisi AF, Sasahara AA. Serial studies of platelet factor 4 and beta thromboglobulin during exercise in patients with coronary artery disease. Am Heart J 1985; 10: 293-9.

20. Marcella JJ, Nichols $A B$, Johnson LL, Owen $J$, Reison DS, Kaplan KL, Cannon PJ. Exercise-induced myocardial ischemia in patients with coronary artery disease: lack of evidence for platelet activation or fibrin formation in peripheral venous blood. J Am Coll Cardiol 1983; 1: 1185-93.

21. Mant MJ, Kappagoda CT, Quinlan J. Lack of effect of exercise on platelet activation and platelet reactivity. Exerc Physiol 1984; 57: 1333-7.

22. Davis RB, Boyd DG, MCKinney ME, Jones CC. Effects of exercise and exercise conditioning on blood platelet function. Med Sci Sports Exerc 1990; 22: 49-53.

23. Drygas WK. Changes in blood platelet function, coagulation, and fibrinolytic activity in response to moderate, exhaustive, and prolonged exercise. Int $J$ Sports Med 1988; 9: 67-72.

24. Ricci G, Masotti M, Mazzoni G, Grazzi, Casoni I. Platelet count, mean platelet volume, and platelet dimensional width in professional cyclists during races. Thromb Res 1991; 62: 791-3.

25. Wersch JWJ, Kaiser V, Janssen GME. Platelet system changes associated with a training period of 18-20 months: A transverse and a longitudinal approach. Int J Sports Med 1989; 10: 181-5.

26. Janssen GME. Marathon running: functional changes in male and female subjects during training and contests. Int $J$ Sports Med 1989; 10 (suppl 3): 117-90.

27. Jovicic A, Mandic S. Circadian variations of platelet aggregability and fibrinolytic activity in healthy subjects. Thromb Res 1991; 62: 65-74. 
28. Dawes J, Pumphrey CW, McLaren KM, Prowse CV, Pepper DS. The in-vivo release of human platelet factor 4 by heparin. Throm Res 1982; $27: 65-76$.

29. Saggin L, Cazzola F, Corona G, Salvatico E, Cella G, Prosdocimi $M$. Neutralization of the antiheparin activity of platelet factor 4 by a monoclonal antibody. Thromb Heamostas 1992; 67: 137-43.

30. Zawilska K, Elikowski W, Zozulinska M, Turowiecka Z . The influence of physical exercise and intravenous heparin on plasmatic concentration of platelet factor 4 in young survivors of myocardial infarction. Thromb Res 1989; 55: 155-60.

31. Resina A, Fedi S, Leoncini G, Ventimiglia V, Vecchiet $L$, Doni A. Changes of endogenous heparin-like activity during graded physical exercise in man. Thromb Haemostas 1983 (abstr); 50: 422 .

32. Dawes J, Smith RC, Pepper DS. The release, distribution, and clearance of human Bthromboglobulin and platelet factor 4. Thromb Res 1987 ; 12: 851-61. 
Exercise and blood platelets 


\section{CHAPTER 8}

REGULAR PHYSICAL ACTIVITY AND CHANGES IN RISK FACTORS FOR CORONARY HEART DISEASE;

A NINE-MONTHS PROSPECTIVE STUDY

G.A.E. Ponjee, G.M.E. Janssen, J. Hermans and

J.W.J. van Wersch

Submitted to:

European Journal of Clinical Chemistry and clinical Biochemistry 


\section{SUMMARY}

This study reports the non-acute effects of a long-term training programme of increasing intensity on the cardiovascular risk factor profile and the interrelation between these risk factors. Twenty sedentary men and 14 sedentary women were trained 3 to 4 times a week for nine months. After 36 weeks all individuals ran a half marathon run. The training programme induced a median increase in Wmax of $12 \%$ in the group of men and $18 \%$ in the group of women. These increases in wmax did not correlate with any other change in risk factors under investigation in this study: Blood pressure was not altered, but body weight and body mass index were significantly decreased in the male group at the end of the training programme and non significantly in the female group. In the group of men, total cholesterol, low density lipid cholesterol and triglycerides decreased significantly under the influence of the training sessions. Furthermore, in both groups, a great fall in plasma plasminogen activator inhibitor levels was noticed. However, the changes in these lipid and fibrinolytic parameters were not correlated. Initial total cholesterol, low density lipid cholesterol and triglyceride levels correlated significantly with systolic blood pressure, while diastolic pressure was correlated to tissue-plasminogen activator. Since tissue-plasminogen activator also was significantly related to triglycerides, a trias existed between primary risk factors like blood pressure, lipid levels and fibrinolysis. In contrast, the changes in these parameters under the influence of physical training, were not interrelated. Median serum lipoprotein(a) levels were significantly increased in both men and women five days before the half marathon run. Concomitantly, median fibrinogen concentrations were significantly elevated in men and non significantly in women, although no correlation existed between these changes. 
In conclusion, the nine months exercise programme increased the aerobic fitness in both men and women. This improvement coincided but was not correlated with beneficial changes in several anthropometric, lipid and fibrinolyic factors. Improvement in the risk factor profile was more pronounced in men than in women. The changes in lipid and haemostasis risk factors did not correlate with each other. The increases in lipoprotein(a) and fibrinogen concentrations, both atherogenic indices, could actually represent a normal physiological response to the physical strain of exercise training of increasing workload. 


\section{INTRODUCTION}

Atherosclerosis leading to coronary heart disease is still the major cause of morbidity and mortality in our western society (1). Atherosclerosis is a complex multifactorial disorder, but the pathogenesis includes a contributing role for blood lipids and haemodynamic forces (1-3). Occlusion of an atherosclerotic vessel, based on thrombus formation, links the haemostatic system with atherosclerosis at a fundamental level (2-4). Risk factors for atherosclerosis are several anthropometric determinants like sex, age, body weight and blood pressure (5-8). In addition, various biochemical parameters contribute to the formation of atherosclerotic plaques of which hyperlipidaemia, namely an increased serum total and/or low density lipoprotein cholesterol (LDL-cholesterol) is the best known (7-10). other parameters include factors of the haemostatic system, like an elevated plasma fibrinogen or plasminogen activator inhibitor concentration (11-13). Recently lipoprotein (a),

a LDL-like lipoprotein with a great homology to plasminogen, a component of the haemostatic system, was designated as an independent risk factor for the genesis of artherothrombotic disease (14-17).

Regular physical exercise, among other life-style habits like diet and a history of no smoking, may reduce the risk of vascular thrombotic events $(6,18-21)$. This protection might be mediated through the effect of exercise on the haemostatic system and lipid metabolism, because endurance trained athletes exhibit generally more favourable profiles than their non-active counterparts (22-25). The results of longitudinal studies, in which selection bias and constitutional factors have been minimized, are difficult to compare due to differences in e.g. duration and intensity of the exercise programmes $(23,26-30)$. Only few studies exist on the interrelation of anthropometric, Iipid, and haemostatic risk factors and the potentially 
favourable effect of long-term moderate exercise on these parameters $(31-33)$.

The present study was designed to investigate the non-acute effect of long-term physical conditioning on anthropometric and biochemical parameters in previously sedentary men and women and to evaluate the relationship between the specific components of the risk factor profile.

\section{MATERIAL AND METHODS}

\section{subjects}

Threehundred seventy people replied to advertisements in two local newspapers and on a local radio station. Those who participated in any sports such as running or jogging or who were active for more than one hour per week in other recreational sports were excluded. 47 individuals were aselectly chosen to participate in the study. 34 participants completed the 9 months training programme: twenty males aged from 32 to 49 years (median:39 years) and 14 females aged from 27-41 years (median: 35 years). No lipid lowering or antihypertensive medication was used by any of the volunteers. Among the participants were three female and six male cigarette smokers (maximum of ten cigarettes a day), who continued to smoke during the test period. All individuals kept their diet and other living habits, like the use of alcohol as constant as possible during the study. After two information sessions all subjects gave their written informed consent.

\section{Training programme}

After a medical examination and pre-exercise control measurements all volunteers participated in a 9 month endurance training programme preparing for a half marathon run $(21 \mathrm{~km})$. The schedule was essentially the same as previously described by Janssen et al (34). The training period lasted 9 months. After 24 and 36 weeks of training 
all subjects ran a $15 \mathrm{~km}$ and $21 \mathrm{~km}$ race, respectively. During the general preparation period the volunteers trained 3-4 times a week; 6 weeks before each contest the training programme was intensified to 5-6 times a week. Beside the attention paid to style and technique of running, stretching, speed, intervals, warming-up and cooling-down, the training included three elements: longdistance running, running at high speed and interval training. The elements followed each other naturally as far as the intensity is concerned. The intensity percentage of maximal heart rate was for long-distance runs 70-80\%, for running at a fixed pace 80-95\% lover 200-2000 $\mathrm{m}$ depending on the training status) and for intervals over shorter distances $(200-400 \mathrm{~m})$ 95-100\%. By putting these three elements together (in relation of 70:20:108 of the distances per week) a gradual undulating increase of the amount of training can be accomplished by training to a maximum of 60 min per training session in the first part of the study and to a maximum of 100 min per training session in the second part.

\section{Blood samples}

All blood samples were drawn between 8.00 and $9.00 \mathrm{am}$. All subjects were seated and had not eaten or exercised during the preceding ten hours before phlebotomy. Samples were taken before the start of the training programme and, in order to avoid acute effects, five days before both races. Non-traumatic venipuncture was performed by trained technicians. Within one hour from sample collection serum was separated from blood, snap-frozen in aliquots, stored at $-70^{\circ} \mathrm{C}$ in plastic tubes and thawed at $37^{\circ} \mathrm{C}$ immediately prior to serial analysis.

\section{Blood pressure}

Blood pressure was determined using a standard auscultatory method by a skilled technician, after a five minutes rest 
period of the subjects in supine position. For the systolic blood pressure the first korotkoff sounds were noted, while the diastolic blood pressure was measured at the disappearance of the korotkoff sounds.

\section{Graded maximal exercise tolerance test}

Exercise tolerance test was conducted using a Lode bicycle ergometer. The test started at a workload of 50 watt. After a warming-up period of 10 minutes, the exercise intensity was increased by 50 watt every 4 minutes until exhaustion. During the test, subjects cycled at a rate of approximately $80 \mathrm{rpm}$ and heartrate was monitored continuously. Wmax was calculated as the power step at which was cycled for the complete 4 minutes, plus the fraction of power cycled in the final intensity step.

\section{Laboratory procedures}

Fibrinogen was determined according to the clauss method. The antigen concentrations of tissue-plasminogen activator (t-PA; Kabi Vitrum Diagnostica, Molndal, sweden) and lipoprotein(a) (Biopool $A B$, Umea, Sweden) were determined using an ELISA test method. Plasminogen activator inhibitor (PAI) activity was analysed using an excess single chain t$P A$ and S-2251 as an chromogenic substrate for plasmin (Kabi vitrum Diagnostica). Serum triglycerides and total cholesterol were analysed using enzymatic assays (Roche Diagnostica, Basel, Switzerland and Boehringer Mannheim, respectively). High density lipoprotein cholesterol (HDLcholesterol) fraction was isolated from serum by the phophostungstic acid/ magnesium chloride precipitant and determined with a test kit of Boehringer. LDL-cholesterol was calculated according to the Friedewald equation. The intra-assay coefficient of variation for the determination of PAI was less than 10\%. For all other assays the intraassay coefficient of variation was less than $5 \%$. 


\section{statistics}

All statistic computations were done with SPSS/PC+ Statistics 4.0 computer package (SPSS Inc., Chicago, USA). wilcoxon signed rank test was used to compare differences in pre- and post-exercise plasma samples. The Mann-Whitney test was used to compare the male and female population. All data are given as medians and interquartile ranges. Correlations between changes in lipids, lipoproteins and haemostatic factors and changes in anthropometric values were calculated according to the method of spearman. (Stepwise) multiple regression was carried out to find independent determinants for the variation in the increase of Wmax.

\section{RESULTS}

Effect of training on maximal workload and the risk factor profile

Median (interquartile range) initial anthropometric determinants, values of the lipid metabolism, the haemostatic and fibrinolytic system and the changes in these parameters after nine months of training are summarized in Table I. In both men and women a nine months training programme produced a significant increase in wmax. In men this increase was $12 \% \quad(p<0.001)$ and in women 18\% $(\mathrm{p}=0.016)$. In neither men nor women resting diastolic nor systolic blood pressure was changed at the end of the training programme. In men, median body weight and body mass index were significantly $(p<0.01)$ reduced at the end of the training programme, while in the female group a non significant reduction in these anthropometric parameters was noticed. The lipid profile showed a significant $(p<0.01)$ decrease in triglycerides, total cholesterol and LDL-cholesterol in the male group, but not in the female population. In contrast, in both men and women lipoprotein(a) concentrations were significantly $(p<0.01)$ 
higher in both men and women after the completion of the training programme. In the male group fibrinogen concentrations were significantly $(p<0.01)$ raised after nine months, while in the female group the rise in median fibrinogen concentration was not significantly different from pre-training levels. Finally, in both men and women a large and highly significant ( $p<0.001)$ reduction in median PAI levels was observed after nine months of training.

TABLE I: Median (interquartile range) initial anthropometric characteristics and variables of the lipid metabolism and haemosiatic system in men and women and the changes in six nomths (nre postl for these paramnters.

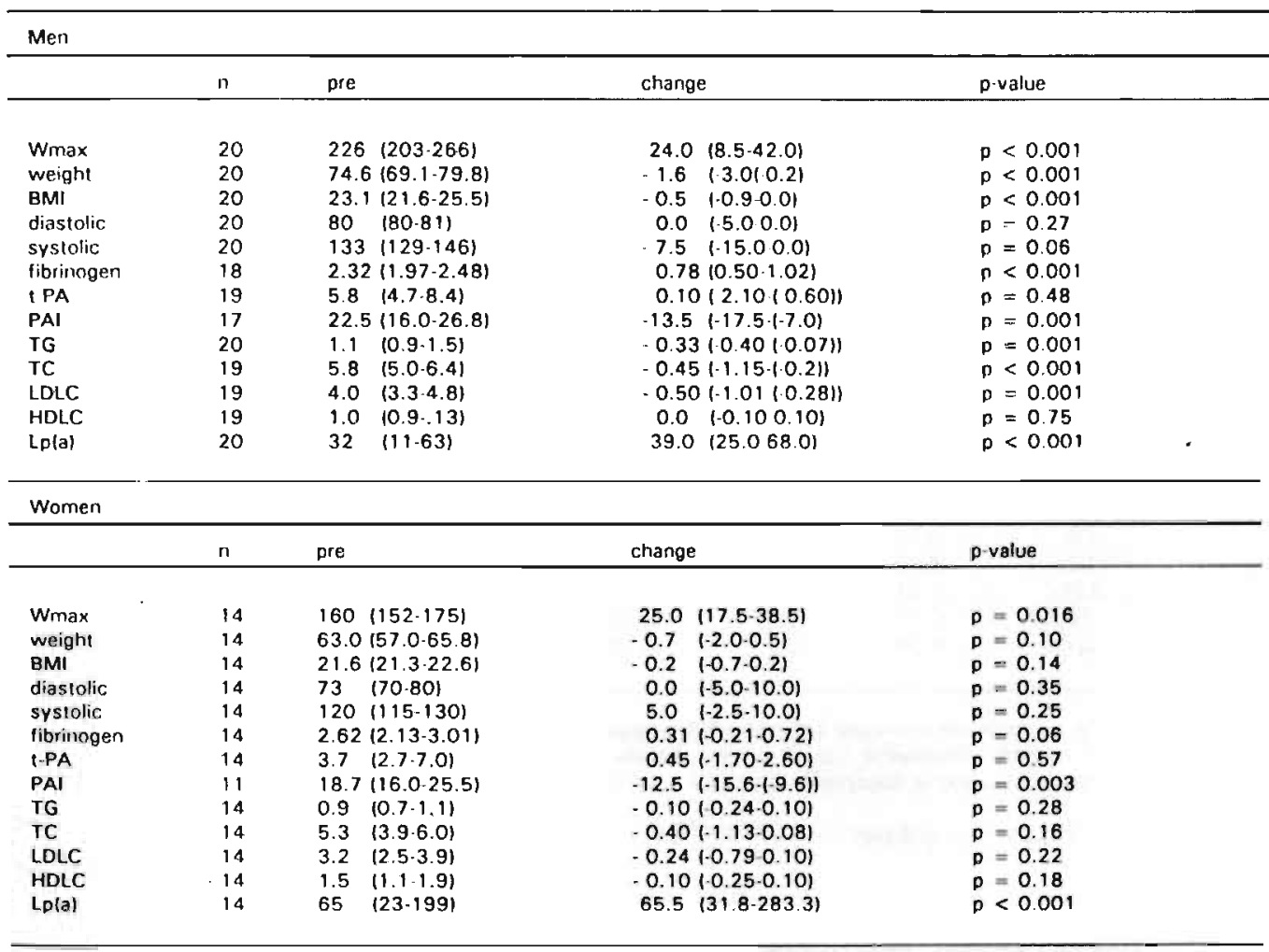

BMI - body mass index; t.PA = tissue plasminogen activator; PAl = plasminogen activator inhibitor:

$T G=$ triglycerittes; $T C=10 t a l$ cholesterol; $L D L C=10 \mathrm{w}$ densily lipid cholesterol; HDLC $=$ high density lipid cholesterol; Lp(a) = lipoprotein (a). 
TABLE II Spearman's rank coefficient of correlation between the change $(\Delta)$ in Wmax and the change in the variables of the risk factor profile after nine months of traınıng.

\begin{tabular}{|c|c|c|c|c|}
\hline & \multicolumn{2}{|c|}{ men } & \multicolumn{2}{|c|}{ women } \\
\hline & $\mathrm{n}$ & $r$ & $\mathrm{n}$ & $r$ \\
\hline a weignt & 20 & 0.04 & 14 & 0.48 \\
\hline$\triangle \mathrm{BMI}$ & 20 & 0.04 & $\vdots 4$ & 0.42 \\
\hline$\Delta$ diastolic & 20 & -0.12 & 14 & -0.32 \\
\hline A systotic & 20 & 0.15 & 14 & 0.03 \\
\hline s fibrınogen & 18 & 0.07 & 14 & 0.15 \\
\hline$\Delta t-P A$ & 19 & .0 .21 & 14 & -0.16 \\
\hline$\therefore \mathrm{PAI}$ & 16 & -0.01 & 10 & -0.57 \\
\hline$\triangle T G$ & 19 & -0.47 & 14 & 0.24 \\
\hline$\triangle T C$ & 19 & -0.04 & 14 & -0.36 \\
\hline$\triangle$ LDLC & 19 & -0.15 & 14 & -0.24 \\
\hline$\triangle$ HDLC & 19 & 0.36 & 13 & -0.02 \\
\hline S Lp(a) & 20 & 0.005 & 14 & 0.18 \\
\hline
\end{tabular}

$\mathrm{BMI}=$ body mass index; $\mathrm{t}-\mathrm{PA}=$ tissue plasminogen activator; $\mathrm{PAl}=$ plasminogen activator inhibitor; TG = triglycerides; TC = total cholesterol; $L D L C=$ low density lipid cholesteral; HDLC = high density lipid cholesterol: Lpla) = lipoprotein (a).

TABLE III Spearman's rank coefficient of correlation between initial anthropometric vartables and initial blood parameters in the total group $(N=34)$.

\begin{tabular}{lcccccc}
\hline & age & Wmax & weight & SMI & diastolic & svstolic \\
\hline fibrinogen & 0.02 & -0.39 & -0.18 & 0.12 & 0.09 & 0.01 \\
t-PA & 0.29 & 0.13 & 0.34 & 0.32 & $0.466^{\circ}$ & 0.39 \\
PAI & -0.10 & 0.07 & 0.36 & 0.21 & 0.08 & 0.03 \\
TG & 0.19 & 0.17 & 0.36 & $0.46^{\circ}$ & 0.32 & $0.60^{\circ}$ \\
TC & 0.32 & -0.02 & 0.05 & 0.27 & 0.19 & $0.55^{\circ}$ \\
LDLC & 0.41 & 0.14 & 0.20 & 0.36 & 0.28 & $0.58^{\circ}$ \\
HDLC & 0.13 & -0.37 & -0.39 & -0.12 & -0.25 & 0.02 \\
Lp(a) & -0.09 & -0.17 & -0.16 & 0.05 & -0.12 & 0.14 \\
& & & & & & \\
\hline
\end{tabular}

I-PA = tissue plasminogen activator; $\mathrm{PAl}=$ plasminogen activator inhibitor; $\mathrm{TG}=$ triglycerides; $\mathrm{TC}=$ total cholesterol; LDLC = low density lipid cholesterol; HDLC = high density lipid cholesterol; $L p(a)=$ lipoprotein $(a)$.

$p<0.01 ; \cdots p<0.001$

\section{Correlation analysis}

Table II shows the correlation (Spearman) between the change in wmax and the change in risk factor profile after nine months of training in men and women. No significant relation existed between the increase in maximal workload 
TABLE IV Spearman's rank coefficient of correlation between changes $(\Delta)$ in parameters of the lipid metabolism and changes $(\Delta)$ in factors of the haemostatic and fibrinolytic system after nine months of training in the total group $(N=34)$.

\begin{tabular}{llllll}
\hline & $\Delta T G$ & $\Delta T C$ & $\Delta L O C L$ & $\Delta H O L C$ & $\Delta$ LP(a) \\
\hline$\Delta$ Fibrinogen & 0.24 & -0.13 & -0.13 & 0.29 & -0.19 \\
$\Delta$ T.PA & 0.09 & -0.04 & 0.28 & -0.16 & -0.03 \\
$\Delta$ PAI & -0.15 & -0.06 & 0.08 & 0.15 & 0.10
\end{tabular}

$\mathrm{t} \cdot \mathrm{PA}=$ tissue plasminogen activator; $\mathrm{PAl}=$ plasminogen activator inhibitor; $\mathrm{TG}=$ triglycerides:

TC - total cholesterol; LDLC - low density lipid cholesterol; HDLC $=$ high density lipid cholesterol:

Lp(a) $=$ lipoprotein (a).

on a cycle ergometer and the change in atherogenic determinants. Table III shows the correlation between initial anthropometric and biochemical parameters for the total group. Diastolic blood pressure was significantly correlated with serum $t-P A \quad(r=0.46, p<0.01)$ while systolic blood pressure related significantly to total cholesterol ( $r=0.55, p<0.001)$, LDL-cholesterol $(r=0.58, \quad p<0.001)$ and triglycerides $(x=0.59, \quad p<0.001)$. Triglycerides also correlated significantly with body mass index $(r=0.45$, $p<0.01)$. Correlation analysis between initial values of the haemostatic and fibrinolytic system and lipid metabolism showed a significant relation between $t-P A$ and serum triglycerides $(r=0.60, p<0.001))$. Finally, the correlation (Spearman) between changes in lipid and lipoprotein metabolism with changes in the haemostatic and fibrinolytic system for the total group are shown in Table IV. No significant relation was found between changes in these biochemical parameters.

\section{Multiple regression}

In the stepwise multiple regression model, dependent variable was the change in Wmax after nine months ( $\Delta$ wax). Independent variables for $\Delta$ Wmax were initial body weight, body mass index, diastolic and systolic blood pressure. 
Using these independent variables, the regression equation had a $R^{2}$ value of $0.33(N=34)$. In the stepwise multiple regression model however, no independent variables were selected for $\Delta$ Wmax.

\section{DISCUSSION}

Several epidemiological studies have revealed that a sedentary lifestyle is an independent risk factor for coronary heart disease, while habitual physical activity may reduce the individual risk for this condition $(6,18$ 21). The protective effect of exercise seems to be mediated through favourable influences on several established anthropometric and biochemical risk factors $(19,27,33)$. vigourous physical activity may directly or indirectly influence body weight, blood pressure and the lipid profile $(22,24)$. Furthermore, beneficial effects of intensive exercise on the haemostatic system are described $(23,25)$. Nowadays, whether the intensity of exercise training, attainable for the majority of people, will provoke similar results, is a topic of investigation $(6,10,28,32,35,36)$.

In our study a nine months exercise programme of moderate intensity resulted in an average increase in wax of $12 \%$ to $18 \%$ in men and women. Although aerobic fitness is commonly expressed as maximal oxygen uptake (VO2max), Wmax is a more stable determinant for aerobic endurance capacity and easier to assess in the laboratory (37). Results of other studies, in which previously sedentary individuals participated in an aerobic training program of moderate intensity, showed increases in vo2max of $10-208(30,35,36)$. These results are comparable with the results of the present study, since vo2max and Wmax are linearly interrelated $(37,38)$. The nine months training programme provoked, besides increases in wmax at all participants, several changes in selected risk factors. However, the change in aerobic endurance capacity was not significantly 
correlated with changes in anthropometric variables or changes in Iipid and haemostatic parameters. Furthermore, in the stepwise multiple regression model, no initial anthropometric variabies were independent piedictors for the changes Wmax. So, an active life style and physical condjtioning by itself influences risk factors, irrespective of anthropometric characteristics or the outcome of the training sessions $(10,12,20,27,39)$. Regular physical activity can lower mean resting blood pressure in moderately hypertensive patients, although this finding is not universal (40-42). In our study, no significant changes were found in diastolic or systolic blood pressure at the end of the training program in neither men or women. However, one can doubt whether a fall in blood pressure in healthy normotensive subjects is likely to be expected $(35,36,43)$. The nine months training programme induced a significant decrease in median body weight and body mass index in the male group, as well as a non significant reduction of body weight and body mass index in the female group. This finding can be explained by the increased energy expenditure of the individuals under investigation as a result of the regular training sessions $(24,33)$. Before the training programme, initial total cholesterol, LDL-cholesterol and triglyceride levels correlated significantly with the systolic blood pressure in the total group, while the diastolic blood pressure was significantly correlated to $t-P A$. Furthermore, a significant relation between $t-P A$ and triglycerides was found. Hypofibrinolysis in patients with hyperlipidaemia has been frequently reported (44-47). Also a high blood pressure seems to. influence fibrinolysis $(48,49)$. The results of the present study focus on the important interplay between primary risk factors, like blood pressure and lipid levels with fibrinolysis (48). The changes in the haemostatic, fibrinolytic and lipid status as a result of long-term training programme has been separately discussed before. 
(50-53). The fall in plasma PAI levels, observed in both men and women and the significant decrease in total cholesterol, LDL-cholesterol and triglycerides in the group men after nine months of training are known favourable effects of physical conditioning $(26,27,30,33,57)$. The changes in these variables were not interrelated, stressing the fact that these parameters as risk factors for atherosclerotic disease behave independently (55). Lipoprotein(a), a LDL-like lipoprotein, competes with plasminogen for fibrin binding in vitro, and therefore may relate atherosclerosis to thrombosis (14-17). Although some studies report an association between lipoprotein(a) levels and fibrinogen concentrations, most investigators failed to find any relation between lipoprotein(a) and factors of the haemostatic or fibrinolytic system (56-58). Also in the present study, the increases in lipoprotein(a) levels in both groups and the increases in fibrinogen levels in the male group at the end of the training programme were not correlated. Lipoprotein(a) levels are often increased in patients suffering from coronary heart disease $(16,59)$. Recently lipoprotein(a) levels in sera of healthy physically active individuals were found to be raised, which parallels the results of the present study (60). Therefore, lipoprotein(a) may play a physiological role as an acute phase reactant in tissue repair, making its function not solely restricted to be an atherogenic determinant $(60,61)$. In the present study, the training sessions in preparation for the half marathon run probably have caused physical stress on the body of the participants, inducing a rise in lipoprotein(a) and also in fibrinogen as acute phase reactants (60-63).

In conclusion, the results of the present study show that regular physical conditioning of moderate intensity influences coronary risk factors at rest. These changes are more pronounced in men than in women. Improvement of anthropometric factors, lipid profile and fibrinolytic 
potential are important favourable effects. Supposed adverse effects of exercising, like increases in lipoprotein(a) and fibrinogen, could actually be a normal physiological response to the physical strain of the exercise programme of increasing workload. 


\section{REFERENCES}

1. Ross $R$. The pathogenesis of atherosclerosis - an update. N Engl J Med 1986; 314: 488-500.

2. Badimon JJ, Fuster V, Chesebro JH, Badimon L. Coronary atherosclerosis; a multifactorial disease. Circulation 1993; 87 (suppl II): II-3 - II-16.

3. Strong JP. Atherosclerotic lesions; natural history, risk factors, and topography. Arch Pathol Lab Med 1992; 116: 1268-75.

4. Von Rokitansky C. A manual of pathological anatomy. London, England: Sydenham Society $1852 ; 4: 261$.

5. Al-Hazzaa HM, Sulaiman MA, Al-Matar AJ, Al-Mobaireek KF. Cardirespiratory fitness, physical activity patterns and coronary risk factors in preadolescent boys. Int J Sport Med 1994; 15: 267-72.

6. Paffenbarger RS, Hyde RT, Wing AL, Lee IM, Jung DL, Kampert JB. The association of changes in physicalactivity level and other lifestyle characteristics with mortality among men. N Engl J Med 1993; 328: 538-45.

7. Håheim LL, Holme I, Hjermann I, Leren P. Risk factors of stroke incidence and mortality; a 12-year followup of the oslo study. Stroke 1993; 24: 1484-9.

8. Marti B, Suter E, Riesen WF, Tschopp A, wanner HU. Anthropometric and lifestyle correlates of serum lipoprotein and apoliprotein levels among normal nonsmoking men and women. Atherosclerosis 1989; 75: 11122 .

9. Hostmark AT, Berg J, Brudal S, Berge SR, Kierulf P, Bjerkedal $T$. Coronary risk factors in middle-aged men as related to smoking, coffee intake and physical activity. Scand J Soc Med 1992; 20: 196-203.

10. Adamopoulos PN, Macrilakis $\mathrm{K}$, Papamichael $\mathrm{Ch}$, Malakos I, Panaydis N, Moulopoulos SpD. Physical activity and relationship with coronary heart disease risk factors. Acta Cardiologica 1993; 6: 523-34.

11. Hamsten A, walldius $G$, Szamosi A, Blombäck $M$. De Faire $U$, Gahlén $G$, Landou C, Wiman B. Plasminogen activator inhibitor in plasma: risk factor for recurrent myocardial infarction. Lancet 1987; i: 3-9.

12. Elwood PC, Yarnell JWG, Pickering J, Fehily AM, O'Brien JR. Exercise, fibrinogen, and other risk factors for ischaemic heart disease. Caerphilly Prospective Heart Disease study. Br Heart J 1993; 69: $183-7$.

13. Ernst $\mathrm{E}$, Resch $\mathrm{KL}$. Fibrinogen as a cardiovascular risk factor: a meta-analysis and review of the literature. Ann Int Med 1993; 118: 956-63.

14. Edelberg $\mathrm{J}, \mathrm{PizzO} \mathrm{SV}$. Why is lipoprotein(a) relevant to thrombosis? Am J Clin Nutr 1992; 56: 791S-2S.

15. Loscalzo $J$, Weinfeld $M$, Fless GM, Scanu AM. Lipoprotein(a), fibrin binding, and plasminogen activation. Arteriosclerosis 1990; 10: 240-5. 
16. Rosengren A, Wilhelmsen L, Eriksson E, Risberg B, Wedel H. Lipoprotein(a) and coronary heart disease: a prospective case-control in a general population sample of middele aged men. BMJ 1990; 301: 1248-51.

17. Hajjar KA, Gavish D, Breslow JL, Nachman RL. Lipoprotein(a) modulation of endothelial cell surface fibrinolysis and its potential role in atherosclerosis. Nature 1989; 339: 303-5.

18. Ekelund LG, Haskell WL, Johnson JL, Whaley FS, Criqui MH, Sheps DS. Physical fitness as a predictor of cardiovascular mortality in asymptomatic North American men. N Engl J Med 1988; 319: 1379-84.

19. Bovens $A M$, van Baak MA, Vrencken JG, Wijnen JA, Saris WH, Verstappen FT. Physical activity, fitness, and selected risk factors for CHD in active men and women. Med Sci Sports Exerc 1992; 5: 572-6.

20. Bijnen FCH, Caspersen CJ, Mosterd WL. Physical inactivity as a risk factor for coronary heart disease: a WHO and International society and Federation of Cardiology position statement. Bulletin WHO $1994 ; 72: 1-4$.

21. Lakka $T A$, Venăläinen JM, Rauramma $R$, Salonen $R$, Tuomilehto J, Salonen JT. Relation of leisure-time physical activity and cardiorespiratory fitness to the risk of acute myocardial infarction in men. New Engl J Med 1994; 330: 1549-54.

22. Mena P, Maynar M, Campillo JE. Plasma lipid concentrations in professional cyclists after competitive cycle races. Eur J Appl Physiol 1991; 62: 349-52.

23. Streiff $M$, Bell WR. Exercise and hemostasis in humans. Semin Hematol 1994; 31: 155-65.

24. Stray-Gundersen J, Denke MA, Grundy SM. Influence of lifetime cross-country skiing on plasma lipids and lipoproteins. Med Sci Sports Exerc 1991; 23: 695-702.

25. Gough SCL, Whitworth S, Rice PJS, Grant PJ. The effect of exercise and heart rate on fibrinolytic activity. Bl Coagul Fibrinol 1992; 8: 179-82.

26. Després JP, Tremblay A, Moorjani S, Lupien PJ، Thériault G, Nadeau A, Bouchard C. Long-term exercise training with constant energy intake. 3: effects on plasma lipoprotein levels. Int $J$ obes 1990; 14: 8594.

27. Findlay IN, Taylor RS, Dargie HJ, Grant S, Pettigrew AR, Wilson JT, Aitchison $T, C l e l$ and JGF, Elliott AT, Fisher BM, Gillen G, Manzie A, Rumley AG, Durnin JVGA. Cardiovascular effects of training for a marathon run in unfit middle aged men. Brit Med $\mathrm{J}$ $1987 ; 295$ : $521-4$.

28. Superko HR. Exercise training, serum lipids, and lipoprotein particles: is there a change threshold? Med Sci Sports Exerc 1991; 23: 677-85.

29. Thompson PD, Cullinane EM, Sady SP, Flynn MM, Bernier 
DN, Kantor MA, Saritelli AL, Herbert PN. Modest changes in high-density lipoprotein concentration and metabolism with prolonged exercise training. Circulation 1988; 78: 25-34.

30. Stratton JR, Chandler WL, Schwartz RS, Cerqueira $\mathrm{MD}$, Levy WC, Kahn SE, Larson VG, Cain KC, Beard JC, Abrass IB. Effects of physical conditioning on fibrinolytic variables and fibrinogen in young and old healthy adults. Circulation 1991; 83: 1692-7.

31. Krobot $K$, Hense HW, Cremer $P$, Eberle $E$, Keil U. Determinants of plasma fibrinogen: relation to body weight, waist-to-hip ratio, smoking, alcohol, age, and sex. Arteriosclerosis Thromb 1992; 12: 780-8.

32. Young DR, Haskell WL, Jatulis DE, Fortmann SP. Associations between changes in physical activity and risk factors for coronary heart disease in a community-based sample of men and women: the stanford Five-City project. Am J Epidemiol 1993; 138: 205-16.

33. Wood PD, stefanick ML, Dreon DM, Frey-Hewitt B, Caray SC, williams PT, superko HR, Fortmann SP, Albers JJ, Vranzian KM, Ellsworth NM, Terry RB, Haskell WL. Changes in plasma lipids and lipoproteins in overweight men during weight loss through dieting as compared with exercise. New Engl J Med 1988; 319: $1173-9$.

34. Janssen GME. Marathon running: Functional changes in male and female subjects during training and contests. Int J Sport Med 1989; 10 (suppl 3) : 117-90.

35. Grant $S$, Aitchison $T$, Pettigrew $A R$, orrell JM. The effects of a university fitness programme on healthrelated variables in previously sedentary males. Br J Sp Med 1992; 26: 39-44.

36. Stein PK, Boutcher SH. The effect of participation in an exercise training program on cardiovascular reactivity in sedentary middle-aged males. Int $J$ Psychophysiol 1992; 13: 215-23.

37. Arts FJP, Kuipers $H$. The relation between power output, oxygen uptake and heart rate in male athletes. Int $J$ Sports Med 1994; 15: 228-31.

38. Hawley JA, Noakes TD. Peak power output predicts maximal oxygen uptake and performance time in trained cyclists. J Appl Physiol 1992;65:79-83.

39. Hellénius ML, de Faire U, Berglung B, Hamsten A, Krakau I. Diet and exercise are equally effective in reducing risk for cardiovascular disease. Results of a randomized controlled study in men with slightly to moderately raised cardiovascular risk factors. Atherosclerosis 1993; 103: 81-91.

40. Gordon NF, Scott CB. Exercise and mild essential hypertension. Primary Care 1991; 18: 683-94.

41. Blumenthal JA, Siegel WC, Appelbaum M. Failure of exercise to reduce blood pressure in patients with mild hypertension. JAMA 1991; 266: 2098-2104.

42. Seals DR, Hagberg $J M$. The effect of exercise training 
on human hypertension: a review. Med Sci Sports Exerc 1984; 16: 207-15.

43. Gilders RM, voner $C$, Dudley GA. Endurance training and blood pressure in normotensive and hypertensive adults. Med Sci Sports Exerc 1989; 21: 629-36.

44. Greig HBW, Glasg MB. Inhibition of fibrinolysis by alimentary lipaemia. The Lancet 1956; i: 16-8.

45. Donders SHJ, Lustermans FATh, van wersch JWJ. Fibrinolysis factors and lipid composition of the blood in treated and untreated hypertensive patients. Bl Coagul Fibrinol 1992; 3: 61-7.

46. Mehta J, Mehta P, Lawson D, Saldeen T. Plasma tissue plasminogen activator inhibitor levels in coronary artery disease: correlation with age and serum triglyceride concentrations. J Am Coll Cardiol 1987; 9: 263-8.

47. Andersen P. Hypercoagulability and reduced fibrinolysis in hyperlipidemia: relationship to the metabolic cardiovascular syndrome. J Cardiovascular Pharmacol 1992; 20 (suppl 8): S29-S31.

48. Jansson JH, Johansson B, Boman $K$, Nilsson TK. Hypofibrinolysis in patients with hypertension and elevated cholesterol. J Int Med 1991; 229: 309-16.

49. Urano T, Kojima Y, Takahashi M, Serizawa K, Sakakibara K, Takada Y, Takada A. Impaired fibrinolysis in hypertension and obesity due to high plasminogen activator inhibitor-1 level in plasma. Jpn J Physiol 1992; 43: 221-8.

50. Ponjee GAE, Janssen GME, van Wersch JWJ. Prolonged endurance exercise and blood coagulation: a 9 month prospective study. Bl Coagul Fibrinol 1993; 4: 21-5.

51. Ponjee GAE, Janssen GME, van Wersch JWJ. Effect of long-term endurance exercise on fibrinolytic markers. Fibrinol 1993; 7: 397-400.

52. Ponjee GAE, Janssen GME, Hermans $J$, Van wersch JWJ. Effects of long-term exercise of moderate intensity on anthropometric values and serum lipids and lipoproteins. Eur J Clin Chem Clin Biochem, submitted.

53. Ponjee GAE, Janssen GME, Van wersch JWJ. Long-term exercise and lipoprotein(a) levels in a previously sedentary male and female population. An Clin Biochem 1995; 32: 1-5.

54. Gris JC, Schved JF, Aguilar-Martinez P, Arnaud A, Sanchez $N$. Impact of physical training on plasminogen activator inhibitor activity in sedentary men. Fibrinol 1990; 4: supp 2, 97-8.

55. De Geus EJC, Kluft C, De Bart ACW, Van Doornen LJP. Effects of exercise training on plasminogen activator inhibitor activity. Med Sci sports Exerc 1992; 24 : 1210-9.

56. Heinrich J, Sandkamp $M$, Kokott $R$, Schulte $H$, Assmann G. Relationship of lipoprotein(a) to variables of 
coagulation and fibrinolysis in a healthy population. Clin Chem 1991; 37: 1950-4.

57. Glueck CJ, Glueck HI, Tracy T, Speirs J, McCray C, Stroop D. Relationships between lipoprotein(a), lipids, apolipoproteins, basal and stimulated fibrinolytic regulators, and d-dimer. Metabolism $1993 ; 42$ : 236-46.

58. Halvorsen $S$, Skjonsberg $O H$, Berg $K$, Ruyter $R$, Godal HC. Does Lp(a) lipoprotein inhibit the fibrinolytic system? Thromb Res 1992; 68: 223-32.

59. Oshima $S$, Uchida $K$, Yasu $T$, Uno $K$, Nonogi $H$, Haze $K$. Transient increase of plasma lipoprotein(a) in patients with unstable angina pectoris. Arterioscler Thromb 1991; 11: 1772-7.

60. Cardoso GC, Posadas $\dot{C}$, orvanaños 00 , Peniche $C$, Zamora J. Aguilar R, Holguin JA, Raynaud AS, Morrisett JD, Guevara J. Long distance runners and body-builders exhibit elevated plasma levels of lipoprotein(a). Chem Phys Lipids 1994; 67/68: 207-21.

61. Craig WY Ledue TB. Lipoprotein(a) and the acute phase response. Clin Chim Acta 1992; 210: 231-2.

62. Arai $M$, Yorifuji $H$, Ikematsu $S$, Nagasawa $H$, Fujimaji $M$, Fukutake $K$, Katsumura $T$, Ishii $T$, Iwane $H$, Influences of strenucus exercise (triathlon) on blood coagulation and fibrinolytic system. Throm Res 1990; 57: 465-71.

63. Taniguchi N, Hirohiko, Yamauchik. Effects of treadmill exercise on platelet functions and blood coagulating activities in healthy men. Jpn Heart $J$ 1984; 25: 167-80. 


\section{CHAPTER 9}

GENERAI DISCUSSION 


\section{GENERAL DISCUSSION}

Leisure time physical exercise is more and more appreciated as a way to improve physical fitness and general health. In large epidemiologic studies, physical activity and physical fitness are associated with a reduced risk of cardiovascular disease and premature death (1-4). This seems to be mediated through favourable effects of exercise on a number of coronary risk factors (5-7). However, epidemiologic studies are observational in design, leaving space for potential bias. A large long-term randomized controlled trial on the single-factor effect of physical exercise on coronary risk factors has so far never been conducted ( 8 ). The great variability in the compliance of the participants due to the excessive demands of intensive training programmes, the difficulty to manage these type of studies and the high costs coming with it, are probably the major cause for this. Instead, most longitudinal studies on the effect of physical exercise on the risk factor profile are restricted to a limited, well selected group of individuals, often only men (9-12). In most studies, the follow-up time was relatively short. Furthermore, generally, only data from the acute postexercise state were collected.

To avoid some of these limitations, the present study was designed to evaluate the long-term, non-acute effects of a nine months physical training programme on a group of healthy men and women. About 370 volunteers were recruited from advertisements in a local newspaper and on a local radio station. Only strictly sedentary individuals were allowed to participate in the study. All were initially motivated to adapt an intensive training programme to their regular daily activities. From all selected individuals (more than 150), a non-select sample was taken of 47 persons, an adequate group size in comparison to other comparable study designs (13-15). The ratio between men and 
women was equal to the ratio between male and female subscribers to this training programme. The study started with a sports medical check-up, including a maximal cycle ergometer-test, which was repeated 9 months later. In this study, the individuals function as their own controls, i.e. all parameters under investigation were determined before the start of the study. Seasonal influences on these parameters were excluded on the basis of results of previous studies $(16,17)$. All participants were strongly advised to keep their other life-style habits unchanged during the training programme and they were intensively controlled. The actual exercise programme was successfully used previously under professional guidance, when preparing a comparable sedentary group for a marathon run (18). Considering the intensity of the training schedule, dropout rate of $28 \%$ was relatively low and the compliance to participate in all training sessions was high.

The training programme induced a significant increase of the maximal workload on a bicycle ergometer (Wmax) in both men and women. However, these increases in aerobic power did not correlate with any other change in anthropometric or biochemical factors under investigation in this study. So, physical activity and physical fitness influenced several selected risk factors, independent of the effect of the training programme on the endurance capacity. Blood pressure was not altered, as could be expected in a healthy normotensive population (19). Pexcentage body fat was decreased in the total group, together with an actual decrease in body weight and body mass index in the male group at the end of the training programme. Although all dietary habits remained essentially unchanged during the training period, body fat reduction is the inevitable result of an increased energy expenditure due to a more active life-style $(20,21)$.

In the male group, serum levels of total cholesterol, low 
density lipoprotein cholesterol (LDL-cholesterol) and triglycerides decreased significantly under the influence of the training sessions. In the female group lipid- and lipoprotein levels did not change. Whether exercise or weight loss through exercise is responsible for the improvement of lipoprotein profiles in the male group is not clear. Some studies show that improvement in lipoprotein profiles by exercise is only achieved in combination with actual weight loss (22). However, the changes in serum lipids or lipoproteins did not correlate significantly with the changes in body weight, body mass index or percentage body fat in the male group in our study, suggesting a primary effect of exercise on serum lipids. More active individuals generally have higher levels of high density lipoprotein cholesterol (HDLcholesterol) (23-25). Increased hepatic lipoprotein lipase activity is held responsible for this, inducing a shift in the relative amounts of $\mathrm{HDL}$-cholesterol subfractions (25). In our study, no change in HDL-cholesterol in either the male or female group was observed. Perhaps measuring total HDL-cholesterol is not a sensitive parameter to detect small changes in HDL-cholesterol concentrations. On the other hand, the amount of cholesterol intake, which remained essentially unchanged in this study group, seems to be important in order to increase HDL-cholesterol concentrations in exercising individuals (9). In the female group, the inefficacy of exercise to alter HDL-cholesterol levels can be caused by the difficulty to override the effects of other, more potent determinants of $\mathrm{HDL}$ cholesterol levels such as female sex hormones $(10,26)$.

In this study, lipoprotein(a) increased steadily and significantly in both the male and female group. Because lipoprotein(a) is considered to be an independent risk factor for cardiovascular disease $(27,28)$, this effect of physical exercise seems to be in contrast with the in general positive effect of endurance training on 
lipoproteins. However, little is known about the function of Iipoprotein(a) in vivo (28). It is speculated that lipoprotein(a), apart from its function as inhibitor of fibrinolysis, is an acute phase determinant $(29,30)$. In a recent study, in sera of long distance runners and body builders, also increased levels of lipoprotein(a) were found, suggesting a non-pathologic role for lipoprotein(a) as a respondent to small tissue damage and tissue repair (31).

A comparable effect was seen when studying the effect of the exercise programme on blood coagulation parameters. Median plasma fibrinogen concentration in the male and female group, a risk factor for coronary heart disease, but also an acute phase reactant, was increased as a result of the training sessions. Lipoprotein(a) binds to fibrinogen in vitro, and in some studies was found that fibrinogen levels were higher in individuals with high levels of lipoprotein(a) $(32,33)$. However, the changes in lipoprotein(a) and fibrinogen concentrations during this training programme were not significantly correlated. Whether these parameters are interrelated as acute phase reactants, should be investigated further.

In contrast to the acute effects of exercise on haemostasis, regular physical training had no long-term effect on blood coagulation, since factor VIII:c activity, von willebrand factor antigen- and thrombin-antithrombin II concentrations remained essentially unchanged. In this study increases in platelet specific proteins as a longterm non-acute effect of physical exercise was observed. The median concentration of platelet factor 4 was significantly elevated at the end of the training programme and was increased almost two-fold, in contrast to the median plasma beta-thromboglobulin concentration. Because of the unequal increase in plasma levels of platelet factor 4, a heparin-binding platelet protein, compared to betathromboglobulin levels, it is less likely that platelet 
factor 4 was solely released from circulating activated platelets. Physical training seems to induce the release of increased amounts of heparin-like substances in the body (34). These endogenous glycosaminoglycans could in turn mobilize a pool of platelet factor 4, normally bound to the vascular endothelium $(34,35)$. This explanation, pointing towards a potential beneficial effect of physical exercise, is speculative and needs further investigation.

Plasma plasminogen activator inhibitor (PAI) activity, which is considered as an important atherogenic index in recent studies, was reduced markedly in both the male and female group at the end of the training programme (36). The underlying physiologic cause for this rapid and large decrease is not clear (37). During the exercise programme the median tissue-plasminogen activator concentrations remained essentially unchanged in both men and women. Because the fraction of active tissue-plasminogen activator is strongly correlated to the average PAI concentration, the concentration of active plasma tissue-plasminogen activator was increased as a result of the exercise sessions, implicating an enhanced fibrinolytic potential of the blood of the volunteers (38). Since the D-dimer concentrations were not altered at the end of the training programme, it can be concluded that this increase in fibrinolytic potential did not result in actual fibrinolysis, which would have been unlikely in absence of an active haemostatic process.

Atherosclerosis is not a single factor disorder but a multi-factorial disease (39). Several metabolic factors were assigned in the past as major and minor risk factors, like impaired glucose tolerance, increased triglycerideand total cholesterol levels, low HDL-cholesterol, obesity and hypertension (40-43). Furthermore, recent studies show that ineffective low fibrinolysis is also a major long-term risk factor $(44,45)$. In patients with hyperlipidaemia, 
hypofibrinolysis has been observed $(46,47)$. Additionally, a high blood pressure seems to influence fibrinolysis (48). In the present study, initial total cholesterol, LDLcholesterol and triglyceride levels correlated significantly with systolic blood pressure, while diastolic pressure was correlated to tissue-plasminogen activator. Tissue-plasminogen activator was also significantly related to triglyceride concentrations. The results of this study confirm the relation between selected primary risk factors. Long-term physical conditioning has a beneficial effect on several of these components (49). The great decrease in plasma PAI levels, observed in both men and women and the significant decrease in triglycerides, total cholesterol and LDL-cholesterol in the male group after nine months of training, are favourable effects of physical conditioning.

The present study was restricted to a selected group of healthy volunteers and most pre-training metabolic parameters of the individuals were in the normal reference range. Therefore the impact of the results of this training programme could only be limited. Taking this in consideration, the effect of physical conditioning on the risk factor profile should be more pronounced in individuals with slight to moderate increased risk to cardiovascular disease. Further research on this subject should therefore include patients with an elevated risk factor profile. Furthermore, longer exercise programs and larger study groups may be needed to get effects comparable with cross-sectional studies.

Recently, it has been proposed that exercise has its favourable. effect on the lipoprotein profile through increased insulin sensitivity $(50,51)$. So, it would be very interesting to investigate in the future the effect of physical training on haemostasis and lipid metabolism in relation to insulin-sensitivity. 


\section{REFERENCES}

1. Kannel WB, Sorlie P. Some health benefits of physical activity. Arch Intern Med 1979; 139: 857-61.

2. Paffenbarger RS, Hyde RT, Wing AL, Lee IM, Jung DL, Kampert JB. The association of changes in physicalactivity level and other lifestyle characteristics with mortality among men. N Engl J Med 1993; 328: $538-45$.

3. Bijnen FCH, Caspersen CJ, Mosterd WL. Physical inactivity as a risk factor for coronary heart disease: a wHO and International Society and Federation of Cardiology position statement. WHO Bull $1994 ; 72: 1-4$.

4. Lakka $T A$, Venăläinen $J M$, Rauramaa $R$, Salonen $R$, Tuomilehto J, Salonen JT. Relation of leisure-time physical activity and cardiorespiratory fitness to the risk of acute myocardial infarction in men. $N$ Engl J Med 1994; 330: 1549-54.

5. Sandvik L, Erikssen J, Thaulow E, Erikssen G, Mundal $R$, Rodahl K. Physical fitness as a predictor of mortality among healthy, middle-aged Norwegian men. N Engl J Med 1993; 328: 533-7.

6. Bovens AM, Van Baak MA, Vrencken JG, Wijnen JA, Saris WH, Verstappen FT. Physical activity, fitness, and selected risk factors for $\mathrm{CHD}$ in active men and women. Med Sci Sports Exerc 1993; 25: 572-6.

7. Young DR, Haskell WL, Jatulis DE, Fortmann SP. Associations between changes in physical activity and risk factors for coronary heart disease in a community-based sample of men and women: the stanford five-city project. An J Epidemiol 1993; 138: 205-15.

8. Curfman GD. The health benefits of exercise; a critical reappraisal. N Engl J Med 1993; 328: 574-5.

9. Ekstedt $B$, Jönsson $E$, Johnson $O$. Influence of dietery fat, cholesterol and energy on serum lipids at vigorous physical exercise. Scand $J$ Clin Lab Invest 1991; 51: 437-42.

10. Blumenthal JA, Matthews $K$, Fredrikson M, Rifai $N$, Schniebolk S, German D, steege J, Rodin J. Effects of exercise training on cardiobascular function and plasma lipid, lipoprotein, and apolipoprotein concentrations in premenopausal and postmenopausal women. Arteriosclerosis Thromb 1991; 11: 912-7.

11. Aellen $R$, Hollmann $W$, Boutellier $U$. Effects of aerobic and anaerobic training on plasma lipoproteins. Int J Sports Med 1993; 14: 396-400.

12. Stratton JR, Chandler WL, Schwartz RS, Cerqueira MD, Levy WC, Kahn SE, Larson VG, Cain KC, Beard JC, Abrass IB. Effects of physical conditioning on fibrinolytic variables and fibrinogen in young and old healthy adults. Circulation 1991; 83: 1692-7.

13. Raz I, Rosenblit $H$, Kark JD. Effect of moderate 
exercise on serum lipids in young men with low high density lipoprotein cholesterol. Arteriosclerosis 1988 ; 8: 245-51.

14. Hespel P, Lijnen P, Fagard R, Van Hoof R, Rosseneu M, Amery A. Changes in plasma lipids and apoproteins associated with physical training in middle-aged sedentary men. Am Heart J 1988; 115: 786-92.

15. McNaughton $L$, Davies $P$. The effects of a 16 week aerobic conditioning program on serum lipids, lipoproteins and coronary risk factors. J Sports Med 1987; 27: 296-302.

16. Costongs GMPJ, Janson PCW, Bas BM, Hermans $J$, van Wersch JWJ, Brombacher PJ. Short-term and long-term intra-individual variations and critical differences of clinical chemical laboratory parameters. J Clin Chem Clin Biochem 1985; 23: 7-16.

17. Costongs GMPJ, Bas BM, Janson PCW, Hermans $J$, Brombacher PJ, van wersch JWJ. Short-term and longterm intra-individual variations and critical differences of coagulation parameters. J $\mathrm{Clin}$ Chem $\mathrm{Cl}$ in Biochem 1985; 23: 405-10.

18. Janssen GME. Marathon running: functional changes in male and female subjects during training and contests. Int J Sports Med 1989; 10 (suppl 3): 11790.

19. Wijnen JAG, Kook MJF, van Baak MA, Kuipers H, de Haan CHA, verstappen FTJ, struijker Boudier HAJ, van Bortel LMAB. Effect of exercise training on ambulatory blood pressure. Int J sports Med 1994; 15: 10-15.

20. Wood PD, stefanick ML, Dreon DM, Frey-Hewitt B, Garay SC, Williams PT, Superko HR, Fortmann SP, Albers JJ, Vranizan KM, Ellsworth NM, Terry RB, Haskell WL. Changes in plasma lipids and lipoproteins in overweight men during weight loss through dieting as compared with exercise. N Engl J Med 1988; 319: 11739 .

21. Alexander $S$. Physiologic and biochemical effects of exercise. Clin Biochem 1984; 17: 126-31.

22. Tran $\mathrm{ZV}$, Weltman $\mathrm{A}$. Differential effects of exercise on serum lipid and lipoprotein levels seen with changes in body weight. JAMA 1985; 254: 919-24.

23. Mena P, Maynar M, Campillo JE. Plasma lipid concentrations in professional cyclists after competitive cycle races. Eur J Appl physiol 1991; 62 : 349-52.

24. Northcote RJ, Canning GC, Todd IC, Ballantyne D. Lipoprotein profiles of elite veteran endurance athletes. Am J Cardiol 1988; 61: 934-6.

25. Marti B, Suter E, Riesen WF, Tschopp A, wanner HU. Anthropometric and lifestyle correlates of serum lipoprotein and apolipoprotein levels among normal non-smoking men and women. Atherosclerosis 1989; 75 : 
$111-22$.

26. Taylor PA, Ward A. Women, high-density lipoprotein cholesterol, and exercise. Arch Intern Med 1993; 153: 1178-84.

27. Rosengren A, Wilhelmsen L, Eriksson E, Risberg $B$, Wedel H. Lipoprotein (a) and coronary heart disease: a prospective case-control study in a general population sample of middle aged men. BMJ 1990; 301: 1248-51.

28. Simons LA. Lipoprotein(a); important risk factor or passing fashion? Med J Australia 1993; 158: 512-4.

29. Maeda S, Abe A, Seishma M, Makino K, Noma A, Kavade M. Transient changes of serum lipoprotein(a) as an acute phase protein. Atherosclerosis 1989; 78: 14550 .

30. Slunga $L$, Johnson $O$, Dahlén GH, Eriksson $S$. Lipoprotein(a) and acute phase proteins in acute myocardial infarction. Scand $\mathrm{J} \mathrm{Cl}$ in Lab Invest 1992; 52: $95-101$.

31. Cardoso GC, Posadas C, Orvananos 00 , Peniche $C$, Zamora J. Aguilar R, Holguin JA, Raynaud AS, Morrisett JD, Guevara J. Long distance runners and body-builders exhibit elevated plasma levels of lipoprotein(a). Chem Phys Lipids 1994; 67/68: 207-21.

32. Hervio L, Chapman MJ, Thillet J, Loyau S, Anglés-Cano E. Does apolipoprotein(a) heterogeneity influence lipoprotein(a) effects on fibrinolysis? Blood 1993; 82: $392-7$.

33. Heinrich $J$, Sandkamp $M$, Kokott $R$, Schulte H. Assmann G. Relationship of lipoprotein(a) to variables of coagulation and fibrinolysis in a healthy population. Clin Chem 1991; 37: 1950-4.

34. Resina $A$, Fedi $S$, Leoncini $G$, Ventimiglia $V$, Vecchiet $L$, Doni A. Changes of endogenous heparin-like activity during graded physical exercise in man. Thromb Heamostas 1983 (abstr); 50: 422 .

35. Dawes J, Smith RC, Pepper DS. The release, distribution, and clearance of human Bthromboglobulin and platelet factor 4. Thromb Res 1987; 12 : 851-61.

36. Hamsten $A$, Walldius $G$, Szamosi $A$, Blombäck $M$, De Faire U, Dahlén G, Landou C, Wiman B. Plasminogen activator inhibitor in plasma: risk factor for recurrent myocardial infarction. Lancet 1987 ; $i$ : 3-9.

37. Gris JC, Schvedd JF, Agullar-Martinez P, Arnaud A, Sanchez $\mathbf{N}$. Impact of physical training on plasminogen activator inhibitor activity in sedentary men. Fibrinol 1990; 4 supp2: 97-8.

38. Chandler WL, Trimble SL, Loo SC, Mornin D. Effect of PAI-1 levels on the molar concentrations of active tissue plasminogen activator ( $t-P A$ ) and $t-P A / P A I-1$ complex in plasma. Blood 1990; 76: 930-7.

39. Badimon JJ, Fuster V, Chesebro JH, Badimon L. 
Coronary atherosclerosis; a multifactorial disease. Circulation 1993; 87 suppl II-3-16.

40. Gordon T, Castelli WP, Hjortland MC, Kannel WB, Dawber TR. High density lipoprotein as a protective factor against coronary heart disease. Am J Med 1977; 62: 707-14.

41. Leon AS. Age and other predictors of coronary heart disease. Med Sci Sports Exerc 1987; 19: 159-67.

42. Høstmark AT, Berg J, Brudal S, Berge SR, Kierulf $P$, Bjerkedal $T$. Coronary risk factors in middle-aged men as related to smoking, coffee intake and physical activity. Scand J Soc Med 1992; 20: 196-203.

43. Bainton $\mathrm{D}$, Miller $\mathrm{NE}$, Bolton $\mathrm{CH}$, Yarnell JWG, Sweetnam PM, Baker IA, Lewis B, Elwood PC. Plasma triglyceride and high density lipoprotein cholesterol as predictors of ischaemic heart disease in British men. The Caephilly and speedwell collaborative heart disease study. Br Heart J 1992; 68: 60-6.

44. Kannel WB, Wolf PA, Castelli WP, D'Agostino RB. Fibrinogen and risk of cardiovascular disease. JAMA 1987; 258: $1183-6$.

45. Hamsten $A$, Walldius $G$, Szamosi $A$, Blombäck $M$, de Faire U, Dahlén G, Landou C, Wiman B. Plasminogen activator inhibitor in plasma: risk factor for recurrent myocardial infarction. Lancet 1987 ; 1 : 3-9.

46. Ridker PM, Vaughan DE, stampfer MJ, Sacks FM, Hennekens $\mathrm{CH}$. A cross-sectional study of endogenous tissue plasminogen activator, total cholesterol, HDL cholesterol, and apolipoprotein A-I, A-II, and B-100. Arteriosclerosis Thromb 1993; 13: 1587-92.

47. Andersen P. Hypercoagulability and reduced fribrinolysis in hyperlipidemia: relationship to the metabolic cardiovascular syndrome. J Cardiovascular Pharmacol 1992; 20 (suppl.8): S29-S31.

48. Urano T, Kojima Y, Takahashi M, Serizawa K, Sakakibara K, Takada $Y$, Takada A. Impaired fibrinolysis in hypertension and obesity due to high plasminogen activator inhibitor-1 level in plasma. Jpn J Physiol 1993; 43: 221-8.

49. De Geus EJC, Kluft $C$, de Bart ACW, van Doornen LJP. Effect of exercise training on plasminogen activator inhibitor activity. Med Sci sports Exerc 1992; 24: 1210-9.

50. Saito $I$, Nishino $M$, Kawabe $H$, Wainai $H$, Hasegawa $C$, Saruta $T$, Nagano $S$, Sekihara $T$. Leisure time physical activity and insulin resistance in young obese students with hypertension. Am J Hypertens 1992; 5 : $915-8$.

51. Laws A, Reaven GM. Evidence for an independent relationship between insulin resistance and fasting plasma HDL-cholesterol, triglyceride and insulin concentrations. J Int Med 1992; 231: 25-30. 


\section{SULOSARY}

This thesis describes the non-acute effects of a nine months training programme of increasing intensity on the cardiovascular risk factor profile in a group of healthy, previously sedentary individuals. Several parameters of blood coagulation, fibrinolysis, blood platelets, lipid metabolism and the interrelation between these variables were studied.

In chapter 1 gives a general overview of several risk factors for coronary heart disease. Life-style factors and blood parameters, influencing the risk for cardiovascular disease, are summarized. Besides established risk factors, like smoking, high blood pressure, high cholesterol or low HDL-cholesterol, attention is paid to several haemostatic risk factors, such as fibrinogen and plasminogen activator inhibitor. Furthermore, lipoprotein(a) as coronary risk factor is discussed. Finally, an outline of the potentially beneficial effect of physical exercise on the risk factor profile is presented.

Chapter 2 describes the selection procedure of the subjects and the concept of the training programme, as well as the materials and methods used. Seventy four participants were selected from 370 people, who replied to advertisements in a local newspaper and on a local radio station. Thirty four volunteers fulfilled the study. Twenty sedentary men and 14 sedentary women were trained 3 to 4 times a week for nine months. After 24 weeks all subjects ran a $15 \mathrm{~km}$-race and after 36 weeks a half-marathon $(21.1 \mathrm{~km})$ race. Six weeks before each contest, the training schedule was intensified to 5 to 6 times a week. Exercise tests were performed and anthropometric values were determined before and after the training programe. Blood samples were drawn before the start of the training programme and, in order to avoid the 
measurement of acute effects, 5 days before both races and 5 days after the half marathon run.

In chapter 3, the influence of endurance training on serum lipids, lipoproteins and some anthropometric parameters is reported. In the male group, median body weight and body mass index were significantly decreased after nine months of training, while in the female group body weight and body mass index remained essentially unchanged. Percentage body fat, measured by skinfold thickness, was significantly decreased in both groups at the end of the training programme. During the training period, median serum total cholesterol, LDL-cholesterol and triglyceride concentrations decreased significantly in the male group, while in the female population the median serum lipid and lipoprotein concentrations did not differ from pre-training values. The changes in serum lipids or lipoproteins did not correlate significantly with changes in body weight, body mass index or percentage body fat. stepwise multiple regression showed that these changes were mostly dependent on initial serum levels. Finally, no significant increase in median $\mathrm{HDL}$-cholesterol was observed in either the male or female group.

Chapter 4 presents the effects of regular exercise on serum lipoprotein(a) concentrations. Lipoprotein(a) is a LDL-like lipoprotein, with great structural homology to plasminogen, a zymogen of the fibrinolytic system. However, in contrast to plasminogen, lipoprotein(a) has an inactive proteolytic site. Lipoprotein(a) is considered to be an independent risk factor for cardiovascular disease. Although the function of lipoprotein(a) is still unknown, it is speculated that Iipoprotein(a) competes with plasminogen for fibrin(ogen) binding sites, and so inhibiting fibrinolysis and promoting thrombus formation.

Before the start of the training programme, median (inter- 
quartile range) lipoprotein(a) values in the male group were $32(11-63) \mathrm{mg} / \mathrm{l}$ and in the female group 65 (23-199) $\mathrm{mg} / \mathrm{l}$. After 24 weeks of training median (interquartile range) serum lipoprotein(a) concentrations were elevated significantly in both the male and female group. Moreover, after 36 weeks of training, in preparation for the half marathon competition, median lipoprotein(a) levels were increased almost two-fold in both groups and were still elevated five days later. It is speculated that lipoprotein(a) is an acute phase reactant. The potentially adverse effect of physical conditioning on lipoprotein(a) levels, may actually represent a normal physiologic response to the physical strain of an exercise programme of increasing intensity.

In chapter 5, the long-term overall effect of physical exercise on several blood coagulation parameters is evaluated. Discussed are plasma factor VIII coagulant (factor VIII:c) activity, von willebrand factor antigen, thrombin-antithrombin III and fibrinogen concentrations. Factor VIII:c activities and von willebrand factor antigen concentrations did not increase during the training programme. In both groups, no significant changes in plasma thrombin-antithrombin II concentrations were observed during the training programme. In both males and females, median plasma fibrinogen concentrations were not enhanced after 24 weeks of training. However, after 36 weeks, fibrinogen levels were increased in the male group, preparing for the $21.1 \mathrm{~km}$ race and were raised significantly in both groups five days later. Because fibrinogen is an acute phase reactant, the increase in fibrinogen concentrations could be a physiologic response to the intensified training sessions, in preparation for the half marathon run.

The long-term overall effect of habitual physical exercise 
on fibrinolysis, is studied in chapter 6. After the training period, median plasma tissue-plasminogen activator antigen concentrations remained essentially unchanged in both the male and female population. In contrast, plasma plasminogen activator inhibitor activities already were significantly decreased in both groups after 24 weeks of training and continued to decrease during the course of the training programme. No increased fibrinolytic activity was observed, since plasma D-dimer concentrations were not changed after the test period.

In chapter 7 presents the non-acute effects of a long-term exercise programme on blood platelets. Median (interquartile range) pre-training values of platelet factor 4 and beta-thromboglobulin for the total group were 9 (5-35) $\mathrm{IU} / \mathrm{ml}$ and $69(40-495) \mathrm{IU} / \mathrm{ml}$, respectively. During the course of the training programme, plasma platelet factor 4 concentrations increased steadily and significantly in both the male and female group, together with a non-significant rise in plasma beta-thromboglobulin. No difference existed in median platelet factor 4 and beta-thromboglobulin concentrations of the male and female population, before or during the training programme. The significant elevated concentrations platelet factor 4, a heparin binding protein, in comparison to beta-thromboglobulin concentrations, could be caused by recirculation of a heparin mobilizable pool of platelet factor 4, normally bound to the endothelium. Increased amounts of heparin-like substances, produced by the body as a result of the physical exercise, might be responsible for this effect.

In chapter 8, the effect of a nine months training programme on the risk factor profile and the correlation between these factors, is discussed. The training programme induced a median increase in aerobic capacity (expressed as Wmax) of 128 in the group men and $18 \%$ in the group women. 
These increases in Wmax did not correlate with any other change in risk factors under investigation in this study. Blood pressure was not altered, but body weight and body mass index were significantly decreased in the male group at the end of the training programme, together with a significant reduction in percentage body fat in both groups. In the group men, serum total cholesterol, LDLcholesterol and triglyceride concentrations decreased significantly under the influence of the training sessions. Whether the observed reduction in serum lipid levels is a primary effect of physical conditioning, or is caused by the concomitant decrease in body weight, is not clear.

In both groups, a great and significant fall in plasma plasminogen activator inhibitor levels was noticed. As a consequence, the fibrinolytic potential of the blood could have been increased. However, fibrinolysis was not enhanced, since D-dimer levels remained unchanged.

Initial total cholesterol, LDL-cholesterol and triglyceride levels correlated significantly with systolic blood pressure, while diastolic blood pressure was correlated to tissue-plasminogen activator antigen concentrations. Since tissue-plasminogen activator antigen concentrations also were significantly related to serum triglycerides, a trias existed between the primary risk factors, blood pressure, lipid levels and fibrinolysis. However, the changes in these parameters under the influence of physical training, were not interrelated.

Median serum lipoprotein(a) levels were significantly increased in both men and women five days before the half marathon run. Concomitantly, median fibrinogen concentrations were significantly elevated in men and non significantly in women. Because both parameters are risk factors for cardiovascular disease, this seems to be an adverse effect of physical exercise. However, fibrinogen is an acute phase reactant and it is speculated that lipoprotein(a) has also acute phase properties. Increases 
in these parameters can therefore be a normal physiologic response to small tissue damage and tissue repair as a result of a regular performed physical exercise.

\section{In summary}

Prolonged physical conditioning of moderate intensity has beneficial effects on lipid and lipoprotein concentrations of male runners, but does not essentially influence lipid and lipoprotein profiles in female runners.

An exercise programme covering increasing distances, significantly increases lipoprotein(a) levels.

An exercise programme of increasing intensity induces physical stress, which has significant effects on plasma fibrinogen concentration, even at rest. But, in contrast to acute post exercise effects, a regular physical fitness programme does not induce a longterm activation of the haemostatic system.

Long-term physical conditioning leads to a marked decrease in plasminogen activator inhibitor activity, without an actual increase of fibrinolytic end products.

Prolonged physical conditioning of increasing intensity is associated with mainly an elevation of the platelet protein platelet factor 4 concentration.

A nine months exercise programme increases the aerobic fitness in both men and women. This improvement coincides but is not correlated with beneficial changes in several anthropometric, lipid and fibrinolytic factors.

The increases in lipoprotein(a) and fibrinogen concentrations, both atherogenic indices, can actually represent a normal physiological response to the physical strain of exercise training of increasing workload. 


\section{SAMENVATTING}

Dit proefschrift beschrijft de niet-acute effecten van een negen maanden durend trainingsprogramma van toenemende intensiteit op een aantal risicofactoren van hart- en vaatziekten bij een groep gezonde vrijwilligers. verschillende parameters van de bloedstolling, fibrinolyse, bloedplaatjes en vet-huishouding evenals hun onderlinge relaties werden bestudeerd.

Hoofdstuk 1 geeft een algemeen overzicht van de diverse risicofactoren voor hart-en vaatziekten en het mogelijk gunstig effect hierop van lichamelijke inspanning.

Besproken worden de bekende risicofactoren, zoals roken, een hoge bloeddruk en een hoog cholesterol gehalte en/of een laag HDL-cholesterol-gehalte. Daarnaast wordt aandacht besteed an diverse risicofactoren voor cardiovasculaire aandoeningen op het gebied van de hemostase, zoals fibrinogeen en plasminogeen activator inhibitor. Tenslotte wordt de rol van lipoproteine(a) als risicofactor besproken.

Hoofdstuk 2 beschrijft de selectieprocedure van de proefpersonen, de opbouw van het trainingsprogramma en de methoden, welke gebruikt zijn voor de analyses.

zevenenveertig mannen en vrouwen werden geselecteerd uit 370 inschrijvingen voor het trainingsprogramma. Twintig mannen en 14 vrouwen hebben de gehele studie afgerond. De deelnemers trainden 3 à 4 maal per week gedurende 9 maanden. Na 24 weken liepen alle vrijwilligers een wedstrijd over $15 \mathrm{~km}$ en na 36 weken een halve marathon $(21,1 \mathrm{~km})$. Zes weken voor iedere wedstrijd werd het trainingschema geintensiveerd tot 5 à 6 maal per week trainen. Inspanningstests op een fietsergometer en de bepaling van diverse anthropometrische indices werden uitgevoerd voor de start van het trainingsprogramma en 9 
maanden later. Bloedmonsters werden afgenomen voor de start van het trainingsprogramma en, om acute effecten van de inspanning te vermijden, 5 dagen voor beide wedstrijden evenals 5 dagen na de halve marathonloop.

In hoofdstuk 3 wordt de invloed van duurtraining op de lipide- en lipoproteineconcentraties in serum en op enkele anthropometrische parameters beschreven. Bij de groep mannen nam het mediane lichaamsgewicht en de body mass index na 9 maanden trainen significant af, terwijl bij de groep vrouwen lichaamsgewicht en body mass index ongewijzigd bleven. Het percentage lichaamsvet, bepaald door het meten van 4 lichaamsplooien, was in beide groepen significant gedaald.

Gedurende het trainingsprogramma nam de mediane totale cholesterolspiegel, het LDL-cholesterol-gehalte en het triglyceridegehalte in het serum van de mannelijke deelnemers significant af, terwijl bij de vrouwen deze parameters onveranderd bleven ten opzichte van de uitgangssituatie. De veranderingen in serum lipide- en lipoproteinegehaltes bij de mannen correleerden niet met de afname in lichaamsgewicht, body mass index of het percentage lichaamsvet. Multiple regressie analyse toonde aan dat deze veranderingen het meest afhankelijk waren van de initiële serum spiegels. Tenslotte, noch bij de groep mannen noch bij de groep vrouwen nam de mediane HDLcholesterol spiegel significant toe.

In hoofdstuk 4 worden de resultaten gepresenteerd van de invloed van regelmatige lichamelijke inspanning op het serum lipoproteine(a) gehalte. Lipoproteine(a), een op LDLcholesterol gelijkend lipoproteine, heeft een moleculaire structuur, welke sterk overeenkomt met plasminogeen, een belangrijk zymogeen van het fibrinolytisch systeem. Echter in tegenstelling tot plasminogeen, bezit lipoproteine(a) geen proteolytische activiteit. Lipoproteine(a) wordt 
beschouwd als een onafhankelijke risicofactor voor hart- en vaatziekten. Hoewel de functie van lipoproteine(a) nog niet opgehelderd is, zou het een remmer van de fibrinolyse kunnen zijn, door interferentie met de binding van plasminogeen aan fibrinogeen.

Voor de start van het trainingsprogramma waren de mediane (interquartielen) uitgangswaarden van lipoproteine(a) in de groep mannen $32(11-63) \mathrm{mg} / 1$ en bij de groep vrouwen 65 (23-199) $\mathrm{mg} / 1$. Na 24 weken trainen, waren de mediane serumwaarden bij de groep mannen en vrouwen significant toegenomen. Na 36 weken trainen waren de serumwararden in beide groepen bijna verdubbeld ten opzichte van de beginsituatie. Een verklaring voor dit schijnbaar ongunstige effect van regelmatige sportbeoefening kan liggen in het feit, dat lipoproteine(a) mogelijk een acute fase eiwit is. Lipoproteine(a) spiegels zouden in deze studie toegenomen kunnen zijn als reactie op de toenemende trainingsintensiteit als voorbereiding op de beide wedstrijden.

Hoofdstuk 5 handelt over het lange termijn effect van lichamelijke inspanning op diverse parameters van de bloedstolling. Besproken worden de fluctuaties in plasma factor VIII:C activiteit, von willebrand antigeen concentraties, trombine-antitrombine III spiegels en fibrinogeen gehaltes. De factor VIII activiteit en de von willebrand antigeen concentraties namen niet toe als gevolg van langdurig trainen. Noch bij de groep mannen, noch bij de groep vrouwen werden wijzigingen gevonden in de mediane plasma trombine-antitrombine III spiegels gedurende het trainingsprogramna. Daarentegen was zowel bij de groep mannen als bij de groep vrouwen de mediane plasma fibrinogeen concentratie na 36 weken gestegen, gemeten tijdens de voorbereiding op de halve marathonwedstrijd. Een toename in fibrinogeen, een acute fase eiwit, kan het gevolg zijn van de toegenomen trainingsintensiteit als voorbereiding op de halve marathon. 
In hoofdstuk 6 wordt het lange termijn-effect van lichamelijke inspanning op de fibrinolyse besproken.

In beide groepen bleef de mediane plasma weefsel plasminogeen activator concentratie onveranderd tijdens de studie. Daarentegen daalde de mediane plasma plasminogeen activator inhibitor activiteit in beide groepen significant na 24 weken trainen en bleef het verder dalen gedurende de rest van het trainingsprogramma. Een toegenomen fibrinolyse werd echter niet waargenomen, aangezien de mediane plasma D-dimeer concentratie niet veranderde gedurende de trainingsperiode.

Hoofdstuk 7 beschrijft het effect van regelmatige duursportbeoefening op de bloedplaatjes-activiteit.

Mediane (interquartielen) uitgangswaarden van de plaatjesspecifieke eiwitten, plaatjesfactor 4 en betatromboglobuline, waren respectievelijk 9 (5-35) IU/ml en 69 (40-495) IU/ml. Gedurende het trainingsprogramma nam de plaatjes factor 4 activiteit significant toe in beide groepen, terwijl de beta-tromboglobuline concentratie niet significant steeg. De sterke stijging van plaatjesfactor 4 , een heparine-bindend eiwit, ten opzichte van betatromboglobuline, zou kunnen duiden op het recirculeren van een voorraad platjesfactor 4, gebonden aan de vaatendotheelcellen. Dit zou veroorzaakt kunnen worden door de toegenomen aanmaak van heparine-achtige substanties door het lichaam als gevolg van de regelmatige duurtraining.

In hoofdstuk 8 wordt het effect van het negen maanden durend trainingsprogramma op de gemeten risicoparameters besproken, evenals de interactie tussen deze factoren. Het trainingsprogramma veroorzaakte een toename in aerobe capaciteit (uitgedrukt als Wmax) van 128 bij de groep mannen en $18 \%$ bij de groep vrouwen. De toename in wmax correleerde niet met én van de andere veranderingen in de gemeten parameters. 
De bloeddruk bleef ongewijzigd. Het percentage lichaamsvet nam in beide groepen significant af, tezamen met een afname in lichaamsgewicht en body mass index bij de groep mannen. In de groep mannen daalde tevens het totaal cholesterol, het LDL-cholesterol en de triglyceride concentratie als gevolg van de trainingen. Of de daling van de lipide spiegels direct een gevolg is van de frequente trainingen of veroorzaakt wordt door de gewichtsafname ten gevolge van het trainen is niet duidelijk.

In beide groepen werd een sterke afname in de plasma plasminogeen activator inhibitor activiteit waargenomen. De hiermee gepaard gaande mogelijke toename in fibrinolytische capaciteit van bloed, leidde niet tot een daadwerkelijke toename in fibrine splits produkten. De wijzigingen in lipide- en fibrinolytische parameters waren niet gecorreleerd. De uitgangswaarden van het totaal cholesterol, LDL-cholesterol en triglyceriden correleerden significant met de systolische bloeddruk, terwijl de diastolysiche bloeddruk gecorreleerd was met de plasma weefsel plasminogeen activator activiteit. Aangezien de beginwaarden van de plasma weefsel plasminogeen activator antigeen concentratie ook gekoppeld waren aan de triglyceridespiegels, bestond er derhalve een trias tussen de primaire risicofactoren bloeddruk, serum lipidespiegels en fibrinolyse. De wijzigingen in deze parameters onder invloed van de trainingsessies waren echter niet gecorreleerd.

Bij zowel de mannen als de vrouwen namen de serum lipoproteine(a) spiegels significant toe als gevolg van regelmatige duursportbeoffening. Tegelijkertijd waren de plasma fibrinogeen concentraties toegenomen. Aangezien beide parameters risikofactoren zijn voor hart- en vaatziekten, lijkt dit een ongunstig effect te zijn van regelmatig trainen. Fibrinogeen is echter tevens een acute fase eiwit en lipoproteine(a) mogelijk ook. Stijging in de bloedwaarden van deze factoren zou derhalve een gevolg 
kunnen zijn van een normale fysiologische reactie op lichamelijke stress.

\section{Conclusies}

Langdurige regelmatige lichamelijke inspanning heeft een gunstig effect op serum lipide- en lipoproteine concentraties bij mannen, mar beïnvloedt de lipideen lipoproteine spiegels bij vrouwen niet significant.

Een trainingsprogramma van toenemende intensiteit veroorzaakt een verhoging van serum lipoproteine(a) spiegels.

Een trainingsprogramma van toenemende intensiteit veroorzaakt lichamelijke stress, welke mogelijk de oorzaak is van de verhoogde plasma fibrinogeen spiegels. Echter, in tegenstelling tot de acute effecten van trainen, leidt regelmatige duursportbeoefening niet tot een lange termijn toename van de bloedstolling.

Regelmatige duurtraining induceert een sterke afname in de plasminogeen activator inhibitor activiteit, echter zonder een gemeten toename in fibrinolyse.

Langdurige training heeft een toename in het plaatjes specifieke eiwit, plaatjes factor 4 tot gevolg.

Een negen maanden durend trainingsprogramma leidt tot een toename in aërobe capaciteit bij mannen en vrouwen. Deze toename gaat gepaard met, maar is niet gecorreleerd aan, gunstige veranderingen in diverse anthropometrische variabelen, parameters van de vethuishouding en fibrinolyse.

De toename in de lipoproteine(a) en fibrinogeen concentratie, beide risikofactoren voor hart-en vaatziekten, zou echter ook een normale fysiologische respons kunnen zijn op de steeds toenemende intensiteit van het trainingsprogramma. 


\section{DANKWOORD}

Alhoewel slechts de naam van één auteur op het voorblad prijkt, wordt een proefschrift nooit alleen geschreven. Ook deze dissertatie is tot stand gekomen dankzij de hulp en steun van velen.

Als eerste wilde ik hierbij mijn co-promotor en zeer gewaardeerde collega Jan van Wersch bedanken, die gedurende het gehele onderzoek een inspirerende en drijvende kracht is geweest.

Mijn promotor, Paul Brombacher heb ik leren kennen als een innemend en motiverend mens en wil ik bedanken voor zijn grote betrokkenheid.

Eugène Janssen wil ik bedanken voor alle tijd en energie die hij in het onderzoek heeft gestoken.

Jo Hermans ben ik dankbaar voor zijn waardevolle adviezen op het gebied van de statistiek.

De analisten op het lab van Jan van Wersch worden bedankt voor hun inzet bij de uitvoering van de laboratoriumtesten. Alle vrijwilligers in het zuiden des lands, die bij dit project betrokken waren, worden eveneens bedankt voor hun tijd en inzet.

Verder wil ik mijn collega's en naaste medewerkers van het Diagnostisch centrum SSDZ bedanken voor hun bemoedigende woorden, geduld en de ruimte die zij mij boden om met hoofd en hart aan dit project te kunnen werken.

Met name Maurits Pekelharing wil ik bedanken voor zijn steun en niet aflatend optimisme over de goede afloop.

Leo van de Hout bedank ik voor zijn begrip en goede humeur, en Niels de Jonge voor zijn hulp bij het gebruik van het SPSS computerprogramma.

Ine olsthoorn krijgt van mij een hele dikke zoen voor al het secretariêle werk dat zij voor mij heeft gedaan. Ook de hulp van Ans Attema, Ella van de kooy, Adrie Adam en Tineke Gijsen heb ik steeds zeer gewaardeerd. 
De directie van het Reinier de Graaf Gasthuis wil ik bedanken voor de ondersteuning van dit proefschrift.

Mijn lieve en zorgzame ouders ben ik zeer dankbaar voor het feit dat $z i j$ altijd voor mij klaar staan.

verder wil ik hierbij mijn naaste familieleden en goede vrienden bedanken voor hun warme belangstelling.

Als laatste, maar feitelijk op de eerste plaats, bedank ik mijn lieve echtgenoot Bert, zonder wie ik nooit een dergelijk project tot voltooiing zou hebben gebracht.

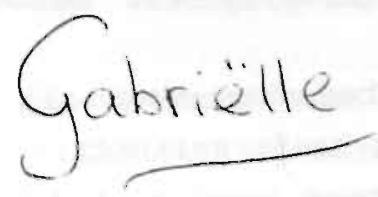


De auteur van dit proefschrift werd geboren op 21 september 1960 te Roosendaal. Het diploma gymnasium-B werd aldaar behaald in 1978 aan het st. Norbertuscollege. In datzelfde jaar werd aangevangen met de studie scheikunde aan de Universiteit van Utrecht, waar in 1982 het kandidaatsexamen S2 behald werd. In de doctoraal fase, welke werd afgerond in 1987, was haar hoofdvak biochemie (prof dr H. de Gier) met de bijvakken klinische chemie (prof dr J.B.J. Soons, St. Antonius ziekenhuis, Nieuwegein) en klinische neurofarmacologie (prof $\mathrm{dr} \mathrm{Tj}$. B. van Wimersma Greidanus; prof dr s. Childers, University of Florida, Gainesville, Florida). Tijdens deze studie werd tevens het C-diploma stralingsdeskundigheid en een onderwijsbevoegdheid behaald. In februari 1987 begon zij aan de opleiding tot klinisch chemicus in het $\mathrm{St}$. Joseph ziekenhuis te Eindhoven (nu Veldhoven), onder leiding van dr ir H.L. Vader. Registratie als erkend klinisch chemicus volgde 4 jaar later.

Vanaf 1 maart 1991 is Gabriëlle Ponjee werkzaam als hoofd van de afdeling Hematologie van het Diagnostisch Centrum SSDz te Delft, alwaar dit proefschrift bewerkt is. Vanaf 1 december 1994 is $z i j$ tevens aangesteld als hoofd van de afdeling Klinische Chemie van hetzelfde instituut. 
